UNIVERSIDADE DE SÃO PAULO

FACULDADE DE FILOSOFIA, LETRAS E CIÊNCIAS HUMANAS

DEPARTAMENTO DE LETRAS ORIENTAIS

PROGRAMA DE PÓS-GRADUAÇÃO EM ESTUDOS JUDAICOS E ÁRABES ÁREA DE CONCENTRAÇÃO: ESTUDOS ÁRABES

DANIEL ALONSO DE ARAUJO

\author{
O ESTABELECIMENTO DA METAFÍSICA \\ COMO CIÊNCIA FILOSÓFICA NO \\ LIBER DE PHILOSOPHIA PRIMA SIVE SCIENTIA DIVINA, \\ DE AVICENA
}

Versão corrigida

SÃO PAULO 
UNIVERSIDADE DE SÃO PAULO

FACULDADE DE FILOSOFIA, LETRAS E CIÊNCIAS HUMANAS

DEPARTAMENTO DE LETRAS ORIENTAIS

PROGRAMA DE PÓS-GRADUAÇÃO EM ESTUDOS JUDAICOS E ÁRABES ÁREA DE CONCENTRAÇÃO: ESTUDOS ÁRABES

DANIEL ALONSO DE ARAUJO

\title{
O ESTABELECIMENTO DA METAFÍSICA COMO CIÊNCIA FILOSÓFICA NO LIBER DE PHILOSOPHIA PRIMA SIVE SCIENTIA DIVINA, DE AVICENA
}

\author{
Dissertação apresentada ao \\ Programa de Pós-Graduação em Estudos Judaicos e Árabes \\ do Departamento de Letras Orientais \\ da Faculdade de Filosofia, Letras e Ciências Humanas \\ da Universidade de São Paulo \\ para obtenção do título de "Mestre em Letras".
}

Orientador: Prof. Dr. Livre-Docente Miguel Attie Filho

Versão corrigida

SÃO PAULO 
Prof. Dr. Miguel Attie Filho Orientador-Presidente da mesa

Prof. Dr. Safa Alferd Abou-Chahla Jubran Examinador.

Prof. Dr. Clarisse Ferreira da Silva Examinador. 


\title{
Resumo
}

O objetivo da presente pesquisa consiste numa tradução e comentários dos três primeiros capítulos do primeiro tratado do Liber de Philosophia Prima sive Scientia Divina - "Livro referente à Primeira Filosofia ou Ciência Divina" -, de Avicena, que trata do estabelecimento da Metafísica como ciência filosófica a partir da delimitação de seu objeto formal e de sua conveniente denominação.

Palavras-chave: metafísica, teologia racional, filosofia medieval.

\begin{abstract}
The objective of this research entails translation and commentaries of three first chapters of first treaty of Liber de Philosophia Prima sive Scientia Divina - "Book on First Philosophy or Divine Science" -, of Avicenne, which is about the establishment of Metaphysic as philosophic science from delimitation of its subject matter and its convenient denomination.
\end{abstract}

Keywords: metaphysic, rational theology, medieval philosophy. 


\begin{abstract}
Agradecimentos
Desejo expressar aqui a minha mais profunda gratidão ao meu querido orientador Prof. Miguel Attie Filho, mais que isso, um verdadeiro amigo de todas as horas, nesses anos de jornadas e aventuras por diversas civilizações, culturas e línguas;

à querida Profa. Safa Jubran, qual Anjo tutelar dos alunos, sentimento profundo, mas difícil de traduzir em palavras, cuja simpatia e dedicação se encontra mais em sua essência bondosa do que em qualquer mérito ou demérito que possamos ter;

aos meus estimados colegas do Grupo de Tradução e Pesquisa/CNPQ: "Filosofia Árabe e História do Pensamento";

à discreta, mas sincera amizade que me dedicaram os Professores Mamede e Michel;

o mais profundo reconhecimento ao amigo e Prof. Alexandre Leone, de quem me orgulho de ter sido tantas vezes aluno de história, pensamento e cultura judaica, e do qual alguns conceitos e métodos inspiraram partes dessa pesquisa;

e mesmo aos que alçam voos de águia às contemplações metafísicas, não podem prescindir dos meios materiais, agradeço aqui à CAPES, pelo apoio financeiro prestado.
\end{abstract}




\section{S U M Á R I O}

Introdução

1

Capítulo I: A constituição da Primeira Filosofia como ciência filosófica a partir da delimitação de seu objeto formal em relação às demais ciências .................................. 7

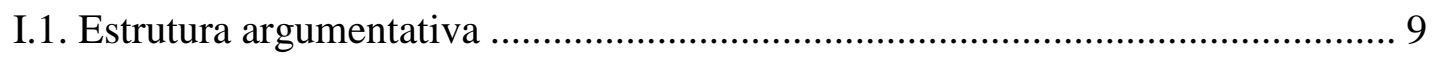

I.2. A Primeira Filosofia e a divisão das ciências ................................................... 10

I.3. A "Ciência Divina" é uma "Theo-logia" (filosófica)? .......................................... 18

I.4. A Primeira Filosofia (ou Sapiência) é uma "Aitio-logia"? ................................. 23

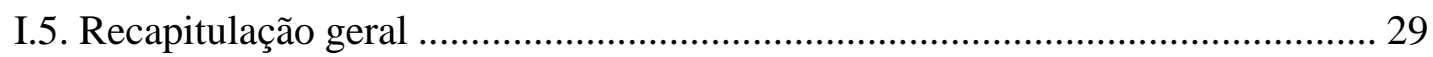

Capítulo II: A determinação do objeto formal da Primeira Filosofia ........................... 32

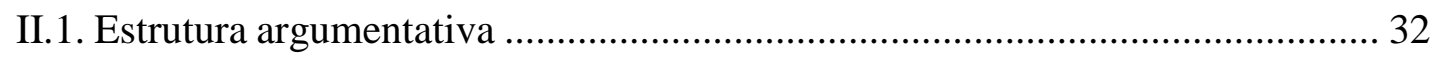

II.2. Uma retomada do objeto formal das ciências filosóficas anteriores ................. 34

II.3. Considerações sobre a especulação referente à "substância" e "existência" ..... 38

II.4. A existência como unidade das "coisas" especuladas nas várias ciências ........ 43

II.5. O “existente” como objeto formal de investigação .......................................... 46

II.6. A divisão desta nova ciência filosófica em partes ............................................ 49

II.7. Comparação da Primeira Filosofia com a Tópica e a Sofística .......................... 55

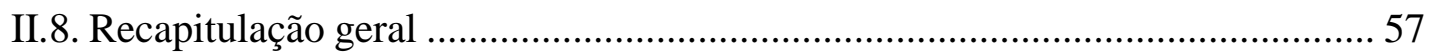

Capítulo III: Qual a utilidade desta ciência, em que ordem ela deve ser estuda e qual a

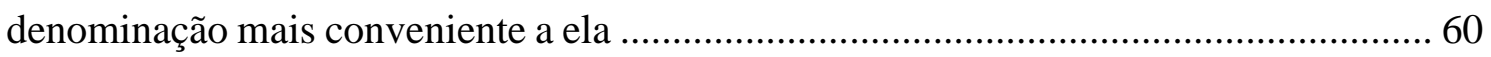

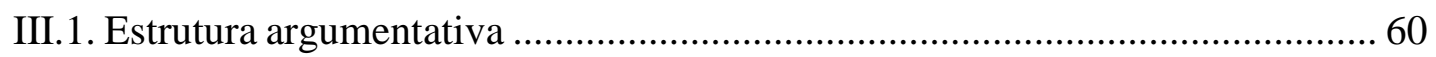

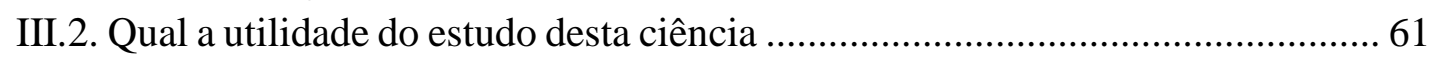

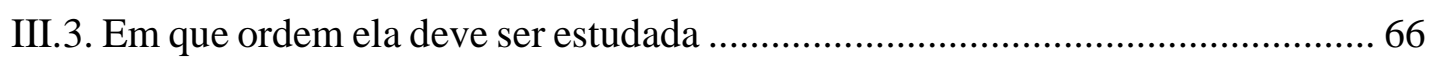

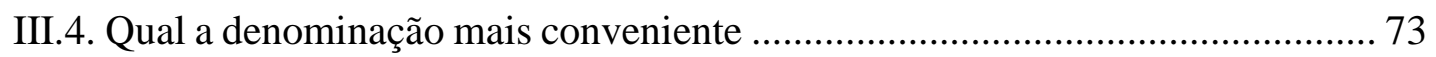

a) Metafisica ou "Profísica" e o que se entende por "natureza" .......................... 74

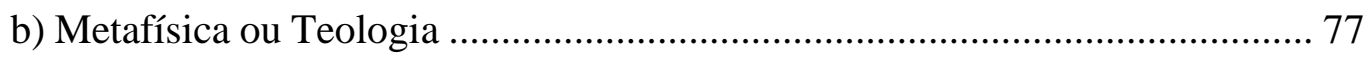

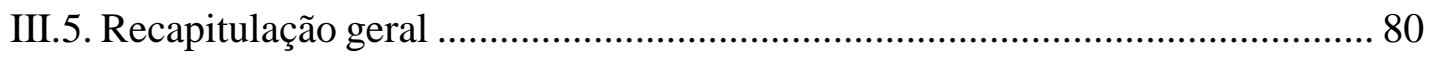

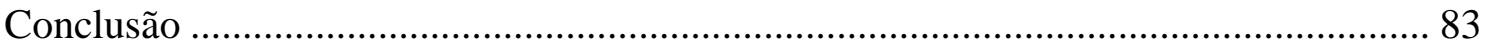

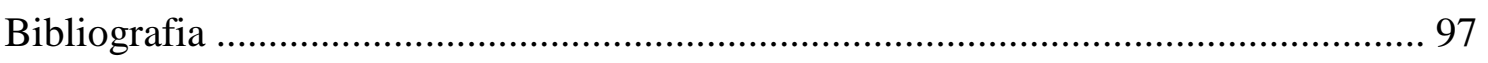




\section{Introdução}

O presente estudo consiste numa tradução comentada dos três primeiros capítulos do Tratado I do Liber de Philosophia Prima sive Scientia Divina, "Livro referente à Primeira Filosofia ou Ciência Divina", nos quais o autor procura estabelecer uma "nova" ciência filosófica a partir da delimitação de seu subiectum, isto é, de seu "campo de investigação", e classificando-a dentre as demais ciências filosóficas.

Uma importância de se estudar esta obra está, entre outras coisas, no fato de ela haver sido amplamente usada pelos intelectuais europeus do século XIII, particularmente nas Universidades de Paris e de Oxford, tendo-se constituído numa espécie de fonte para a formação do que posteriormente se convencionou denominar Metafísica Ocidental, introduzindo elementos aristotélicos "neoplatonizados" na filosofia europeia de então.

Sتاب S referida obra consiste numa versão latina do original em árabe intitulada / Kitāb fi'l-ilāhiy, "Livro sobre a [Ciência] Divina”, de Avicena (Ibn Sīnā), filósofo muçulmano de origem persa (980-1037), cuja tradução foi realizada em Toledo (séc. XII), já sob o domínio castelo-leonês, no período das grandes traduções dos corpora greco-arábico-judaicos que se difundiriam na Europa ocidental fermentando o pensamento filosófico-científico.

Foram diversas as circunstâncias históricas convergentes que possibilitaram uma situação favorável para a realização daquele movimento de traduções de obras filosóficas, científicas e literárias greco-arábico-judaicas ao latim durante os séculos XII-XIII em Toledo, e sua respectiva recepção pela intelectualidade europeia: a) o processo de reconquista da Península Ibérica aos mouros politicamente enfraquecidos; b) a fuga de judeus e muçulmanos perseguidos pelos almôades para Toledo, onde se concentravam grandes colônias judaico-sefardis e cristã-moçarábicas; c) a influência clunisiana mediante a romanização dos cristãos hispano-moçarábicos.

Durante o século XI, toma impulso o processo de reconquista da Península Ibérica aos mouros, por parte da dinastia castelo-leonesa, que se estenderá até o século XV. Com a desintegração do califado de Córdoba e a multiplicação dos reinos de taifas, o islã andaluz sofre um grande enfraquecimento político tornando-se vulnerável ao levante dos cristãos nórdico-peninsulares. Paradoxalmente, as cortes andaluzas promovem as letras, as artes e as ciências magnificamente. Isso foi considerado pela ortodoxia islâmica uma espécie de "mundanização" dos costumes e causa da decadência, favorecendo, dessa maneira, as invasões berberes almorávidas e almôades com intenções reformadoras. 
Em 1085, o Rei Afonso VI de Castela e Leão toma a cidade de Toledo, antiga capital visigótica, que abrigava uma das mais importantes comunidades cristãmoçarábicas durante a dominação islâmica, além do que era a sede primacial da Igreja hispânica. Lá se refugiara, durante o século XII, um grande número de judeus e alguns muçulmanos perseguidos pelos almôades. Essa situação fez de Toledo um lugar privilegiado de encontro das três culturas: arábica, judaica e latina. Sua convivência pacífica, a concentração de um imenso patrimônio intelectual contribuiu imensamente para a fermentação e mútua influência dos três grupos que resultariam num feliz desenvolvimento do que havia sido cultivado durante todo o alto-medievo hispânico. ${ }^{1}$

Nesse período, sob o pontificado de Gregório VII (1073-1085), o movimento clunisiano havia atingido o seu apogeu e vinha penetrando com força entre os cristãos peninsulares, promovendo uma paulatina romanização (ou, mais exatamente, uma francoromanização) da Igreja hispânica, substituindo as práticas moçarábicas consideradas em alguns aspectos desviadas e heterodoxas. Essa situação preparou um terreno propício aos interesses intelectuais de Cluny que resultaria, em pouco tempo, na atividade tradutora.

Desde que fora fundada em 910, a Abadia borgonhesa de Saint Pierre de Cluny havia se tornado o núcleo de um movimento de renovação espiritual e social da cristandade latina na Europa ocidental. Considerando-se o umbilicus Orbis, isto é, o centro do mundo cristão, a Abadia encarna o primado da caridade universal, criando uma ampla rede de relações com a finalidade de uma centralização controlada e abrindo-se ao diálogo com cismáticos (bizantinos), judeus e "maometanos".

Isso contribuiu para um impulso intelectual com a introdução do conhecimento literário, filosófico e científico proveniente de Bizâncio e dos árabes. O primeiro contato com a ciência árabe se deu com Gerberto d'Aurillac (séc X), monge clunisiano, que estudou em sua juventude com sábios andaluzes Matemática e Astronomia. Foi ele quem, por primeiro, introduziu na Europa ocidental os algarismos arábicos, o ábaco, a álgebra e

\footnotetext{
${ }^{1}$ Convém aqui deixar claros três pontos: a) durante a dominação islâmica a comunidade cristã foi reduzida em muitos aspectos à clandestinidade, havendo inclusive momentos de perseguição resultando em martírios. De modo geral, sobre a vida dos cristãos, sobretudo em Córdoba, pesava uma situação difícil, não havendo uma convivência pacífica de tolerância como muitas vezes se vem afirmando; b) é inexata a informação da presença islâmica durante sete séculos na Península, senão somente no extremo sul nas regiões de Córdoba e Andaluzia, visto que já pouco mais de três séculos após a invasão islâmica (séc. VIIIXI), mais da metade da Hispânia já havia sido retomada pelos castelo-leoneses e, ainda, Toledo conservava fortemente a memória de seu passado hispano-visigótico e sua cultura cristã; c) o momento produtivo de cultura intelectual de convivência pacífica das três culturas se deu sob o domínio castelo-leonês e não sob a dominação islâmico-andaluza (Cf. RINCÓN ÁLVAREZ, Mozárabes y Mozarabias. Salamanca: Ed. Universidad Salamannca, 2003, p. 80).
} 
foi o primeiro a construir, na Europa, um astrolábio. ${ }^{2}$ Mas é a Pedro, o Venerável, Abade de Cluny (+1156), que se deve o impulso das traduções ocorridas em Toledo. Suas visitas canônicas aos mosteiros clunisianos levaram-no à Espanha onde tomou contato com o islã. A fim de conhecer melhor a religião e o pensamento dos “mouros", Pedro promoveu a tradução ao latim do Alcorão e de outros textos árabes, dando início ao movimento de traduções toledanas.

Sob o patrocínio do Arcebispo de Toledo, Raymond de Sauvetât (1126-1151), monge clunisiano, formou-se um pequeno núcleo de tradutores que, no período de 11301151, verteram do árabe ao latim um grande número de obras filosóficas e científicas produzidas por pensadores muçulmanos e judeus ou de versões árabes de obras gregas, convertendo Toledo num importante centro de atividade intelectual europeia. Entre outros, destacamos Abraão ibn David, Domingos Gonzáles, Gerardo de Cremona, Marcos de Toledo, Miguel Scoto e Germano, o Alemão. Em fins do século XIII, durante o reinado de Afonso X, o Sábio, houve um segundo círculo de tradutores em Toledo.

Desses tradutores, os que mais nos interessam são os dois primeiros, responsáveis pela tradução de كتاب في الإلثيات Kitāb fi'l-ilāhiy. Abraão ibn David (Avendaud) foi considerado o mais importante filósofo judeu aristotélico anterior a Moisés ben Maimôn (Maimônides) e que lhe preparou o caminho. A sua identidade foi muito debatida em razão da pluralidade dos patronímicos encontrados nos diversos manuscritos ${ }^{3}$, confundindo os filólogos, levando mesmo alguns a sugerirem que se tratava de mais de uma pessoa. Segundo alguns, ele teria se convertido ao cristianismo e adotado o nome de Juan Avendaud de Espanha. ${ }^{4}$

Entretanto, a hipótese de conversão de Ibn David ${ }^{5}$, bem como a de adoção do nome Juan, não passa de conjecturas fundadas em interpretações errôneas dos manuscritos. Segundo o erudito Jourdain ${ }^{6}$, somente em manuscritos tardios do século XIII

\footnotetext{
${ }^{2}$ D'Aurillac foi o primeiro francês a ser eleito Papa, assumindo o nome de Silvestre II (999-1003). A celebridade de sua erudição era tal que apareceram lendas a seu respeito, afirmando que sua sabedoria se originara de um pacto com o diabo, talvez uma alusão aos seus mestres mouros (cf. ROPS, J.-D. A Igreja dos tempos bárbaros. São Paulo: Quadrante, 1993, p. 548).

${ }^{3}$ Iohannes Avendeuth Hispanus, Ioyannes Hispalensi, Ioyannes Limensi, Iohannes Toletanus, Avendeuth, Avended, Avendeath, Abendana, Avendar, Johanes ibn Dâwûd (cf. DE LIBERA, A. A Filosofia Medieval. São Paulo: Ed. Loyola, 2004, p. 347).

${ }^{4}$ Cf. também GUTTMANN, J. A Filosofia do Judaísmo. São Paulo: Perspectiva, 2003, p. 172-181.

${ }^{5}$ Convém recordar que os caracteres hebraicos são desprovidos de vogais e que o nome "David", DVD, era passível de várias grafias, variando a presença de vogais. Por outro lado, não havia a letra "v" no latim antes do século XVI, grafada sempre por "u” ou, mais raramente, por "w”. Assim, Daud, Dawud, Dauid etc. A latinização de Ibn David ficou Avendaud.

${ }^{6}$ Cf. D’ALVERNY, Marie-Thèrése, Avicenne em Occident. Paris: J. Vrin, 1993, p. 19-43.50ss.
} 
aparecem a denominação Iohannes para Avendaud. Na maior parte dos manuscritos do Liber de anima, "Livro sobre a alma", de Avicena, procedentes do século XII, a dedicação vem do seguinte modo: Reverendissimo Toletanae sedis archiepiscopo et Hispaniarum primati Iohanni [não Iohannes] Avendeuth israelita philosophus. Iohanni, no caso dativo, concorda com reverendissimo archiepiscopo, e não com o nominativo Avendeuth israelita philosophus, (Iohannes está no caso nominativo). Portanto, dedica-se "ao reverendíssimo Arcebispo João", e não: dedicado por "João Avendaud, filósofo israelita"7. Em muitos manuscritos posteriores de fins do século XIII e do XIV o nome vinha abreviado em Iohn, provocando, desse modo, uma leitura errônea por parte dos copistas. O fato é que, juntamente com Moshé Sefardi e Rabi bar Hiyya de Barcelona, Ibn David foi um dos judeus que transmitiram para os cristãos a cultura arábica no momento em que os reinos de taifas desabavam. ${ }^{8}$

Domingos Gonzáles, Arcediago de Segóvia, o mais célebre dos tradutores, exerceu também uma atividade filosófica de certo interesse, destacando-se algumas obras originais como De immortalitate animae e De processione mundi, em que se percebe a influência do filósofo judeu Salomão ibn Gabirol (Avicebron). Em seu pensamento, podemos identificar não somente a influência avicebroniana, mas também agostiniana, aristotélica e aviceniana com notáveis coincidências conceituais com a Escola de Chartres e com Hugo de São Vítor. Juntamente com Ibn David, traduziu diversas obras do corpus avicennianum. Consta que, ao fim de sua vida, Gonzáles conhecia o árabe o suficiente para traduzir sozinho toda a Metafísica de Avicena. ${ }^{9}$

Na carta dedicatória que introduz a tradução do Liber de anima, de Avicena, endereçada ao Arcebispo João de Toledo (sucessor de Raymond de Sauvetât) e assinada por Avendaud, podemos encontrar informações referentes às condições e ao método de realização do trabalho: Habetis ergo librum, nobis praecipiente et singula verba vulgariter proferente, et Domenico Archidiacono singula in latinum convertente, ex arábico translatum, "Portanto, eis o livro que traduzimos [translatum ex] do árabe: enquanto eu proferia de antemão cada termo em língua comum, o Arcediago Domingos os traduzia [convertente in] ao latim”.

\footnotetext{
${ }^{7} \mathrm{Na}$ verdade, existem somente três manuscritos datados de fins do século XIII, XIV, os quais contém a variante Iohannes em lugar de Iohanni: o ms. 629da Biblioteca Mazarine, o ms. 463 do fundo Bodley d'Oxford e o ms. Lat. 14854 da Biblioteca Nacional de Paris (cf. D'ALVERNY, op. cit., ibidem).

${ }^{8}$ Cf. DE LIBERA, A. op. cit., p. 347.

${ }^{9}$ Cf. Idem, p. 348; GILSON, E. A Filosofia na Idade Média. São Paulo: Marins Fontes, 2013, p. 461-477; SARANYANA, J.-I. A Filosofia Medieval. Das origens Patrísticas à Escolástica Barroca. São Paulo: I.B.F.C. "Raimundo Lúlio", 2006, p. 202-204.
} 
Muito se pode extrair desta sentença. Comecemos pelo fato de que numa tradução em conjunto supõe-se que não havia fluência de ambos os tradutores nas duas línguas, a língua da qual se traduzia e a língua para qual se traduzia o texto, mas cada um dominava uma das respectivas línguas, havendo necessidade de uma terceira língua comum a ambos pela qual se fazia o câmbio. Ora, Ibn David, como judeu sefardi, conhecia muito bem o árabe, mas ignorava o latim; enquanto que Gonzáles, de origem castelã e clérigo, conhecia bem o latim, mas era pouco versado em árabe. A língua comum (vulgariter) a ambos era, seguramente, o castelão, língua românica, isto é, de origem latina.

Os tradutores toledanos seguiam o procedimento de tradução ad verbum, isto é, uma tradução literal, em que cada termo sintático era vertido, mas se mantinha na mesma posição estrutural da língua originária, conservando inclusive as expressões típicas que poderiam se tornar pouco compreensíveis em outra língua. A escolha desse modo de tradução poderia se explicar pelo fato de ser mais prático, numa situação de um quase ditado, embora uma tradução ad sensum, pelo sentido, não fosse nada inviável.

Dois termos são usados no texto para o nosso equivalente à "tradução": translatio e conversio. O primeiro termo, translatio, literalmente "transferência", é usado neste texto com a preposição ex, "a partir de", indicando a ideia de "tradução a partir de", enquanto que o segundo, conversio, literalmente "mudança", "conversão", é usado neste texto com a preposição in regendo o caso acusativo, "dirigindo-se a", indicando a ideia de "tradução para". ${ }^{10}$

Portanto, era intencional a escolha de um ou de outro modo de tradução e isso se fazia conforme o valor que se dava à obra ou a relação do tradutor com a mesma. Poderia indicar também o gênero e o uso que se faria da obra, a preferência ao caráter estilístico ou de conteúdo ou mesmo a ideologia do tradutor referente ao processo de tradução.

Desde Boécio, os medievais optaram para as traduções dos textos filosóficos pelo método ad verbum, o mesmo usado por Jerônimo para a tradução dos textos sagrados, pois queriam interferir o menos possível no texto original, procurando conservar as construções sintáticas e o estilo redacional do autor a fim de não correrem o risco de alterar a ideia que o autor queria transmitir. Evidentemente isso não deixava a leitura mais fácil, mas exprimia o respeito que os tradutores tributavam a tais obras. $\mathrm{O}$ interesse fundava-se, assim, mais no conteúdo do que na forma, diferentemente da postura adotada frente aos textos literários. Apesar de seus inconvenientes e das críticas movidas pelos

${ }^{10} \mathrm{O}$ latim possui ainda um terceiro termo: interpretatio, que não aparece no citado texto e significa "interpretação", "explicação" e é mais conveniente seu uso com o modo ad sensum. 
humanistas, as traduções ad verbum se apresentaram, frequentemente, com bom grau de exatidão e de qualidade excelente na conservação e transmissão dessas obras.

Foi seguindo esses princípios de tradução que Ibn David e Domingos González procederam ao verterem o كتاب في الإلهيات Kitāb fi'l-ilāhiy ao latim. É notável que a ordem sintática latina do Liber de Philosophia Prima sive Scientia Divina se afasta da estilística clássica, seguida pelos medievais, e se aproxima da ordem quer arábica, quer românica, cujas ordens são próximas entre si, se relacionadas com a latina.

O objetivo do presente estudo consiste em analisar o estabelecimento da Metafísica como ciência filosófica a partir da delimitação de seu objeto formal e consequentemente do sentido da nomenclatura apresentada e discutida pelo autor da obra em questão, Liber de Philosophia Prima sive Scientia Divina, "Livro referente a Primeira Filosofia ou Ciência Divina”, tendo por base os seus três primeiros capítulos, dedicados pelo autor a esse assunto introdutório.

Sendo assim, o presente estudo será divido em três capítulos, cada qual contendo a análise de cada um dos capítulos da obra em questão, elegidos para a presente pesquisa. Procurar-se-á nesses capítulos acompanhar o pensamento de Avicena (bem entendido, do Avicena latino, deixando de lado a construção do pensamento em árabe), como ele vai concatenando as ideias no estabelecimento da ciência metafísica a partir da delimitação de qual seja seu objeto formal e sua relação com as demais ciências filosóficas dentro do esquema de classificação das ciências (filosóficas) e da percepção das realidades extramentais. Disporemos os excertos do texto latino da obra, seguidos de suas respectivas traduções por nós realizada, e depois faremos os comentários. 


\section{Capítulo I:}

\section{A constituição da Primeira Filosofia como ciência filosófica a partir da delimitação de seu objeto formal em relação às demais ciências.}

Neste primeiro capítulo de nossa pesquisa, que ora se inicia, discorrer-se-á como o autor da referida obra propõe a constituição de uma nova ciência filosófica - e aqui entende-se por filosofia o conjunto do saber - que, como se verá adiante, embora seja a última tratada, pois supõe o conhecimento das demais, ela é, de fato, a primeira na ordem de importância por estar relacionada com os fundamentos das outras. Considerando as relações das diversas ciências entre si como um sistema orgânico de mútua dependência, esta "nova" ciência que se propõe consiste no fundamento das demais a partir da qual elas serão construídas.

Não é sem razão que a primeira denominação, ou mesmo qualificação, desta potencial ciência seja Primeira Filosofia ${ }^{11}$, cujo objeto de investigação se encontra naquelas coisas primordiais que não são e nem podem ser tratadas em outras ciências ou filosofias, ou partes da Filosofia, porém, interessam à investigação humana. Desse modo, deve-se encontrar o "espaço intelectual" no qual elas possam ser estudadas. Feito essas considerações introdutórias, iniciemos a análise da argumentação.

O primeiro capítulo do Liber de Philosophia Prima sive Scientia Divina ${ }^{12}$ Tractatus Primus, "Livro referente à Primeira Filosofia ou Ciência Divina - Primeiro Tratado", vem intitulado De inquisitione subiecti primae philosophiae ad hoc ut ostendatur ipsa esse de numero scientiarum, cuja tradução literal é "Sobre a investigação do assunto da Primeira Filosofia, além disso, que a própria seja apresentada existir a partir da classificação das ciências". Deste título, podemos inferir dois pontos: a) o autor intenciona investigar o subiectum ou "assunto" da "primeira filosofia" e, a partir disso, b) classificá-la no conjunto das demais ciências filosóficas. ${ }^{13}$

\footnotetext{
${ }^{11}$ Grafamos em itálico todas as vezes que intencionamos usar a expressão como nomenclatura ainda incerta ou postulada e sem grifo quando a nomeamos simplesmente aceitando a denominação de Avicena.

${ }^{12} \mathrm{O}$ editor optou por usar a letra "v" para grafar o "u" semivogal do latim. Contudo, esse uso, bem como a substituição do "i" semivogal por " "j", não ocorrente na presente edição, foi introduzido somente no século XVI pelo humanista francês Pierre de la Ramée. Os manuscritos da obra de Avicena estão certamente grafados com "u" (cf. COMBA, J. Garmática Latina. São Paulo: Ed. Salesiana, 2004, p. 27).

${ }^{13}$ Recordando aqui que o termo latino numerus pode significar "classe", "ordem", "categoria". Optamos aqui traduzir por "classificação". Quanto à expressão "Primeira Filosofia", procuramos manter a ordem em português que prefere prepor o adjetivo numérico ao substantivo, ao invés do modo latinizante da posposição (não se diz em português, por exemplo, de um homem viúvo recasado se referir à esposa primeira, mas à primeira esposa). Recordamos ainda que, na forma original grega, é a mesma ordem do português: $\pi \rho 0 \tau \eta \phi \imath \lambda \sigma \sigma o \phi ı \alpha$ / protē philosophia, "primeira filosofia".
} 
No primeiro ponto, procuraremos esclarecer o seguinte: o termo latino subiectum significa literalmente "assunto", “tema”, "argumento", “tese”, “objeto", aquilo a respeito do qual trata um discurso ou uma ciência. Aqui, num sentido mais específico, significa "campo ou domínio de investigação", podendo tratar-se de algo em si ou, mais precisamente, um aspecto seu. ${ }^{14}$

Exemplifiquemos: o homem pode ser tema ou assunto de um discurso referente aos seus costumes dentro de um grupo social; ele também pode ser objeto de pesquisa da Medicina, onde privilegia o funcionamento orgânico de sua realidade corpórea e a cura de suas enfermidades; ele pode ser objeto de investigação da filosofia quer natural (física, no sentido clássico da expressão), quer ética; no primeiro, privilegiando a sua realidade psíquica ou anímica, ou mesmo intelectiva; no segundo, a retidão de seu agir conforme a razão.

Em todos esses "pontos de vista", o homem pode ser considerado "objeto material" de sua investigação ou discurso; porém, cada qual o encara sob um aspecto específico, abstraindo de outros elementos, o que denominamos aqui de "objeto formal". Desse modo, o objeto formal - ou seja, o assunto ou campo de pesquisa - da Antropologia é o homem em seu grupo social; da Medicina é a saúde; da Ética, a sua moralidade e assim por diante. ${ }^{15}$

Sendo assim, optamos por traduzir subiectum por "objeto formal" sempre que se referir a ideia de "campo de pesquisa" e, mais raramente, por "objeto", quando se referir à coisa investigada em si e não um aspecto seu. ${ }^{16}$ Desse modo, propomos a seguinte tradução do título do primeiro capítulo: "A investigação do objeto formal da Primeira Filosofia e demonstração de sua existência no que concerne à classificação das ciências".

Tendo feito esses necessários esclarecimentos, passemos agora à análise deste primeiro capítulo da obra em questão.

\footnotetext{
${ }^{14}$ JAPIASSÚ, H. e MARCONDES, D. Dicionário Básico de Filosofia. Rio de Janeiro: Zahar, 2006, verbetes: "substância", "substrato", "sujeito"; STORCK, A. C. "A divisão das ciências segundo Avicena. Texto e notas". In: SOUZA PEREIRA, R. H. (org.). Busca do conhecimento. Ensaios de Filosofia medieval no Islã. São Paulo: Paulus, 2007, p. 270 e 277.

${ }^{15}$ Cf. BETTENCOURT, E. Curso de Filosofia. Rio de Janeiro: Escola "Mater Ecclesiae", 2001, p. 115.

${ }^{16}$ A tradução do substantivo subiectum por "sujeito" é um caso de falso cognato, visto que o termo em português não abarca o sentido do termo latino. Por outro lado, a termo substantivo "sujeito" do português, com o sentido que ele carrega, não deriva etimologicamente do termo subiectum, do latim clássico, mas do substantivo subiectus, do latim medieval, inexistente no latim clássico (cf. ALMEIDA, A. R. (coord.). Dicionário de Latim-Português. Porto: Porto Editora, 2008, verbete: "subiectum"; Lexicon Latim Medii Aevi. Brepol, Turnholti, 1975, verbete: "subiectus"; HOUAISS, Dicionário da Língua Portuguesa. Rio de Janeiro: Objetiva, 2009, verbete: "sujeito".
} 


\section{I.1 Estrutura argumentativa}

A fim de facilitar nossa exposição, procuramos perceber como o texto ${ }^{17}$ do capítulo é construído, se podemos dividir em partes distintas pelo conteúdo e assim, analisá-las individualmente, evidentemente dentro de seu devido "com-texto" ou sua relação orgânica com as outras partes abstraídas. Sendo assim, neste capítulo que ora estudamos, distinguiremos três pontos:

a) uma retomada do que até então foi dito:

$\checkmark$ sobre a classificação das ciências filosóficas;

$\checkmark$ sobre seus respectivo objetos formais;

$\checkmark$ sobre a "ciência divina";

$\checkmark$ sobre a relação desta com a "primeira filosofia" e a "sapiência";

b) uma primeira discussão do objeto formal da "ciência divina":

$\checkmark$ se ela trata de Deus ou de sua existência;

$\checkmark$ refutação deste postulado;

c) discussão se a "primeira filosofia" trata das "últimas causas":

$\checkmark$ exposição do postulado;

$\checkmark$ refutação do mesmo.

Desenvolvamos estes tópicos:

O primeiro ponto relaciona a obra em questão com outras que lhe precederam e que fazem parte de um todo ${ }^{18}$, retomando alguns tópicos pertinentes a fim de dar continuidade à exposição. Isso se torna perceptível pelo uso constante das expressões: "mencionamos em outros livros", "dissemos/afirmamos" (anteriormente), "já ouvistes", "pudeste te ocupar disto nos livros já concluídos" e "se recordas"19.

\footnotetext{
${ }^{17}$ Usamos aqui o vocábulo "texto" em seu sentido etimológico de "tecido"; textus é particípio passado do verbo latino tecere, "tecer", "entrelaçar" e, por metáfora, "narrar", "discorrer", "construir um discurso". ${ }^{18}$ A obra original em árabe, o a Kitäb fi' 'l-ilāhiy, consiste no último livro da obra Al-Šifă', "A Cura", que é uma espécie de "suma de filosofia", escrita de modo didático direcionada a iniciantes. Ela segue o modelo das "introduções ao saber", gênero nascido no século II, em Alexandria, depois estendido ao ambiente greco-romano e sírio-arábico. Essas obras se enquadravam em seis perguntas: 1) o que é a filosofia? 2) por que é chamada assim? 3) qual é a sua intenção? 4) qual a sua finalidade? 5) quais as suas divisões e subdivisões? 6) o que se deve dizer sobre cada uma delas? Nesse contexto, o termo "filosofia" era utilizado para indicar o saber em geral ou a reflexão mais profunda sobre o significado das várias ciências. Em sua obra, Avicena segue a ordem clássica das obras aristotélicas: Lógica, Física, Matemática, Metafísica (cf. ATTIE, M. Falsafa. A Filosofia entre os árabes. São Paulo: Palas Athena, 2002, p. 231-241; MARCHIONNI, A. "Introdução". In: HUGO DE SÃO VÍTOR, Didascálicon. Da arte de ler. Petrópolis: Ed. Vozes, 2001, p. 15).

${ }^{19}$ Essas expressões dirigidas diretamente ao leitor marcam também a forma didática que o autor dá à sua obra.
} 
Nesse primeiro ponto, o autor recorda, ainda, a divisão das ciências filosóficas em especulativas e ativas, expondo resumidamente no que isso consiste, e, em seguida, refere-se brevemente às três divisões das ciências especulativas, mencionando os seus respectivos objetos formais.

Feito isso, o autor recorda, também, aquilo que já foi afirmado em relação à "ciência divina", a terceira na divisão das especulativas, como a ciência das primeiras causas daquilo que se especula nas duas outras ciências especulativas e Deus enquanto causa primordial.

$\mathrm{Na}$ sequência, rememora a relação feita entre a "ciência divina", a "primeira filosofia" e a "sapiência" ${ }^{20}$, o que é cada uma delas e se há uma identidade entre essas três denominações ou qualificações.

No segundo ponto, partindo da questão de que toda ciência tem seu objeto formal, como já fora demonstrado anteriormente, procede à discussão se Deus e sua existência pode ser objeto de pesquisa desta ciência, ou se consiste somente numa questão tratada pela mesma. Conclui esse ponto recordando que algumas antecipações já feitas visavam tão somente preparar o raciocínio do leitor no que será tratado neste livro em questão.

Por fim, no último ponto, procede à discussão se o objeto formal desta potencial ciência filosófica consiste nas "quatro causas" em conjunto ou em cada uma delas em particular. Feita essa ambientação, vamos diretamente ao estudo do texto aviceniano.

\section{I.2. A Primeira Filosofia e a classificação das ciências}

A tese central que Avicena objetiva demonstrar desde o início de seu Liber de Philosophia Prima sive Scientia Divina é que a Primeira Filosofia (ou Metafísica) é uma ciência (filosófica) e que ela satisfaz os requisitos de toda ciência. ${ }^{21}$ No primeiro capítulo da obra em questão, o qual estamos tratando, Avicena procura enquadrar a Primeira Filosofia na classificação das ciências, aproveitando a ocasião para revisar a mesma classificação e os respectivos objetos formais delas.

Avicena inicia o primeiro capítulo do Liber de Philosophia Prima sive Scientia Divina com a seguinte afirmação:

\footnotetext{
20 Preferimos traduzir o termo sapientia por "sapiência" e não "sabedoria", pois, embora serem etimologicamente sinônimas, o uso fez com que a segunda adquirisse uma significação mais abrangente, como habilidades práticas, conhecimento moral ou erudição; enquanto que a primeira se restringe ao conhecimento contemplativo, especulativo ou reflexivo, ou ainda, à ciência divina.

${ }^{21}$ STORCK, op. cit., 277.
} 
Postquam, auxilio Dei, explevimus tractatum de intentionibus scientiarum logicarum et naturalium et doctrinalium, convenientius est accedere ad cognitionem intentionum sapientialium. ${ }^{22}$

"Havendo concluído, com o auxílio de Deus, o tratado referente às intenções das ciências lógicas, naturais e doutrinais ${ }^{23}$, convém agora nos ocuparmos do conhecimento das intenções ${ }^{24}$ das intelectuais". 25

Neste primeiro parágrafo, o autor segue a divisão das ciências em quatro grupos: lógicas, naturais, doutrinais e intelectuais. Ora, as ciências lógicas (que serão tratadas mais detidamente no segundo capítulo) constituem a ciência do raciocínio. Tradicionalmente, ela não é tratada como ciência filosófica, mas como um propedêutico ou instrumental que educa o raciocínio para a reflexão filosófica. Todavia, Avicena aqui a inclui entre as ciências filosóficas, colocando-a provisoriamente abaixo (ou anterior) às ciências naturais. ${ }^{26}$

Os três grupos de ciências, naturais, doutrinais e intelectuais, são assim dispostos de acordo com o modo de percepção que o pensador reflete nas coisas. As ciências naturais ou físicas são aquelas que se constituem a partir da apreensão pelos sentidos anímicos ou psíquicos, ou as faculdades sensoriais da alma ou psique, e pela intuição imediata dos objetos realiza o processo cognitivo dos existentes contingentes corpóreos ou materiais. Corresponde ao que hoje denominamos Filosofia da Natureza.

As ciências doutrinais (ou disciplinares, como será chamada mais adiante no texto de Avicena) são as ciências matemáticas, que se realizam a partir da abstração numérica ou quântica dos corpos. As ciências intelectuais são aquelas que se realizam a partir da

\footnotetext{
22 AVICENNA, Liber de Pholosophia Prima sive Scientia Divina I-IV. “Avicenna Latinus", Edição crítica por S. Van Riet e Introdução por G. Verbek, Louvain/Leiden: E. Peeters/E. J. Brill, 1980, p. 1

${ }^{23}$ A denominação latina doctrinalis, adjetivo de doctrina, "ensino", se dá por uma tradução literal do adjetivo grego mathematike, do substantivo mathesis, "ensino", "aprendizado" (Dicionário LatimPortuguês, verbete: "doctrinalis"; BAILLYA, Dictionnaire grec-français. Paris: Hachette, 1950, verbete: $\mu \alpha \theta \varepsilon \mu \alpha \tau \iota \kappa \eta)$.

${ }^{24}$ Intentio, "intenção", aqui tem o sentido de "finalidade", a faculdade intelectiva que direciona o conhecimento ao seu objeto no real (cf. JAPIASSÚ, op. cit., verbete: "intenção"; MARCHIONNI, op. cit., p. 15).

${ }^{25}$ A tradução do adjetivo latino sapientialis é "intelectual", ou seja, conhecimento relativo ao intelecto (em distinção do conhecimento intuitivo através da percepção dos sentidos psíquicos). O adjetivo português "sapiencial" refere-se à sentenças morais ou à sabedoria do agir prudente. Ele foi introduzido na língua portuguesa no século XVIII a fim de classificar uma categoria de livros bíblicos e, por extensão, à literatura dita "oriental" com a mesma temática (Dicionário Latim-Português, verbete: "sapientiaelis"; HOUAISS, op. cit., verbete: "sapiencial".

${ }^{26}$ Recordemos que esta obra referente à Ciência Divina consiste na última parte de uma obra maior e que está estruturada da maneira como ele apresentou: lógica, natural e doutrinal, tratados já escritos e deste modo ordenados. Essa é a classificação clássica proveniente da tradição peripatética.
} 
abstração do corpóreo ou material e cujo conhecimento se dá pela contemplação ou especulação no intelecto.

Desse modo, podemos inferir que o autor classifica essas ciências em conhecimento inferior, médio e superior, correspondendo à sua concepção cosmológica, ou seja, as ciências inferiores são aquelas que conhecem as coisas sublunares ou abaixo da esfera lunar, o mundo das coisas corruptíveis. A ciência média, tratando da abstração numérica, se direciona a coisas não corruptíveis e, em parte, relacionadas com as coisas supralunares. A ciência superior se volta às coisas próprias do conhecimento divino e está no ápice da intelecção.

Em seguida, Avicena recorda as duas grandes classificações em ciências especulativas e ativas:

Incipiamus ergo, auxiliane Deo, et dicamus quod scientiae philosophicae, sicut iam innuimus in aliis libris, dividuntur in speculativas et activas, et iam innuimus differentiam inter eas. Et diximus quod speculativae sunt illae in quibus quaerit perfici virtus anima especulativa per acquisitionem intelligentiae in effectu, scilicet per adeptionem scientiae imaginativae et creditivae de rebus quae non sunt mostra opera nec nostrae dispositiones. In his ergo finis est certitudo sententiae et opinionis: setentiae enim et opinio non sunt ex qualidade nostri operis nec ex qualitate initii nostri operis secundum quod est initium operis. Praticae vero sunt illae in quibus primum quaerit perfici virtus anima speculativa per adeptionem scientiae imaginativae et creditivae de rebus quae sunt nostra opera, ad hoc ut secundário proveniat perfectio virtutis practicae in moribus. ${ }^{27}$

Iniciemos, portanto, tendo Deus por auxiliar, dizendo porque as ciências filosóficas se dividem em especulativas e ativas, como já mencionamos em outros livros, expondo inclusive a diferença entre elas. Dissemos, ainda, que as ciências especulativas são aquelas nas quais, a faculdade especulativa da alma busca se aperfeiçoar mediante a aquisição da inteligência em efeito, ou seja, da ciência imaginativa e do assentimento das coisas que não são nossas obras, nem nossas disposições. Portanto, o fim almejado está na certeza do parecer e da opinião, pois, o parecer e a opinião não são da qualidade de nossa obra, nem da qualidade do princípio de nossa obra, segundo o que é o princípio da obra. Sendo assim, as [ciências] práticas são aquelas nas quais, principalmente, a faculdade especulativa da alma busca se aperfeiçoar pela aquisição da ciência imaginativa e do assentimento

\footnotetext{
${ }^{27}$ Avicenna, op. cit., p. 1-2.
} 
das coisas que são nossas obras, realizando, de modo secundário, a perfeição da faculdade prática nas [ciências] morais.

As ciências ativas ou práticas são aquelas que se referem a ação moral do homem em relação a si mesmo (ética), a administração familiar (econômica), e a administração pública (civil ou política). Portanto, é uma ciência cuja faculdade especulativa objetiva conhecer os princípios do reto agir individual e social. Quanto às ciências especulativas ou teóricas, estas se referem ao conhecimento daquilo que não constitui nossas ações, mas às coisas extramentais que conhecemos e das quais concebemos uma ideia (imagem mental) que pretende ser uma expressão mental da coisa percebida. ${ }^{28}$

Embora, nada mais mencione, de momento, sobre as ciências lógicas, podemos inferir que, além de o autor tratá-las de ciências filosóficas, parece incluí-las na categoria das ciências especulativas. Nada induz a crer que afirme o contrário, nem a colocá-la fora dessas duas grandes categorias: especulativas e ativas. Portanto, de momento, podemos afirmar que Avicena considera as ciências lógicas como ciências filosóficas especulativas ou teóricas, e não como um simples instrumental educador da razão.

Em seguida, Avicena se refere às três divisões das ciências especulativas ou teóricas:

Et diximus quod speculativae comprehenduntur in tres partes, in naturales scilicet et doctrinales et divinas; et quod suum subiectum naturalium est corpora, secundum quod moventur et quiescunt, et quod de eis inquiritur est accidentalia quae accidunt eis proprie secundum hunc modum; et quod suum subiectum doctrinalium est vel quod est quantitas pure, vel quod est hebens quantitatem, et dispositiones eius quae inquiruntur in eis sunt ea quae accidunt quantitati ex hoc quod est quantitas, in definitione quarum non invenitur species materiae nec virtus motus; et quod divinae scientiae non inquirunt nisi res separatas a materia secundum existentiam et definitionem. ${ }^{29}$

Além disso, afirmamos que as ciências especulativas compreendem três partes, a saber: naturais, doutrinais e divinas. O objeto formal das [ciências] naturais são os corpos, sob o aspecto do movimento e do repouso, investigando-se deles os acidentes que se lhes ocorrem particularmente segundo o modo referido. $\mathrm{O}$ objeto formal das [ciências] doutrinais é a quantidade em si mesma, ou o que possui quantidade,

\footnotetext{
${ }^{28}$ Esta grande obra de Avicena, no caso, a $A l-\check{S}_{i f f}{ }^{\prime}$, se refere tão somente às ciências especulativas ou teóricas, colocando os tratados de Lógica como preparativos. A menção que ele fez das ciências práticas teve por finalidade dar um quadro geral da classificação das ciências. 
investigando as disposições desta que acontecem a partir do que é quantidade, em definição das quais não se encontra o aspecto da matéria, nem a faculdade do movimento. As ciências divinas investigam as coisas separadas da matéria segundo a subsistência e definição.

Avicena aponta as três divisões das ciências especulativas ou teóricas delimitando o objeto formal de cada uma delas: as ciências naturais (ou físicas) que tratam dos corpos em relação aos seus acidentes, isto é, ao que lhe é contingente ou relativo, particularmente no que se refere às mudanças ou alterações das relações internas ou externas de seu sistema (movimento), ou sua imutabilidade (repouso); as ciências doutrinais (ou matemáticas) que investigam a quantidade dos corpos abstraindo de seus aspectos acidentais; as ciências divinas que indagam a respeito das coisas "em si mesmas", segundo sua "subsistência", isto é, segundo o que lhe é intrínseco ou inerente, distinto de seu aspecto corpóreo ou material e, a partir disso, buscar a definição do que a coisa em si é.

Observemos aqui que Avicena qualifica esta última como ciência divina, e não como primeira filosofia, como vem fazendo, ou intelectual, como afirmou no primeiro parágrafo. A indeterminação em sua nomenclatura se deve ao fato de ainda ser uma ciência filosófica incipiente, da qual não há delimitação nem sequer de seu objeto formal. Avicena usa uma terminologia de origem aristotélica - encontrada em sua Metafísica mas cujo sentido ainda não é preciso, necessitando de maior refinação, coisa que se fará ao longo dos primeiros capítulos de sua obra.

Convém notar ainda que a nomenclatura usada, no caso em latim, mas que pode muito bem traduzir literalmente os termos arábicos e seus equivalentes originais em grego, são sempre adjetivos que procuram qualificar e distinguir as diversas partições do conhecimento filosófico. Trataremos disso mais adiante.

Nos parágrafos seguintes, Avicena retoma o que até então foi dito, ou "pré-dito", a respeito da "ciência divina", sua identificação com a "primeira filosofia" e com a "sapiência" por excelência, sem, contudo, delimitar o seu objeto formal. Vejamos o que ele afirma:

Iam etiam audisti quod scientia divina est in qua quaerunt de primis causis naturalis esse et doctrinalis esse et de eo quod pendet ex his, et de causa causarum et de principio principiorum, quod est Deus excelsus. Et hoc est quod potuist attingere ex libris transactis. Ex quibus tamen non plene patuit tibi quid certissime sit subiectum 
divinae scientiae, nisi aliquantula innuitione quam transcurri in libro logicae De Analyticis Posterioribus, si meministi: et quod in ceteris scientiis est aliquid quod est subiectum, et quod aliqua sunt quae inquiruntur in eis, et quod principia aliqua conceduntur in eis ex quibus componitur demonstrativo. Sed tamen per hoc non vere certificatur es quid sit subiectum huius scientiae, scilicet an sit essentia primi principii, ad hoc ut id quod quaerimus in ea sit cognitio proprietatum et actionum eius, vel an sit alia inentio. ${ }^{30}$

Também já ouviste que a ciência divina se encontra na investigação das primeiras causas da existência natural e da existência doutrinal, e do que delas depende; da causa das causas e do princípio dos princípios, que é o Deus excelso. Pudeste te ocupar disto nos livros já concluídos. Todavia, eles não te deram total esclarecimento a respeito do que seja exatamente o objeto formal da ciência divina, a não ser por uma pequena indicação que é rapidamente tratada no livro de Lógica, Os Analíticos Posteriores, se recordas: a) nas outras ciências existe algo que é o objeto formal; b) que, por sua vez, é aquilo que se investiga nelas; c) e que alguns princípios são admitidos nelas a partir dos quais se compõe a demonstração.

No entanto, não se estabelece com precisão o objeto formal desta ciência, ou seja, se existe a essência do primeiro princípio, buscando nela o conhecimento de suas propriedades e ações, ou se há outra intenção.

Avicena recorda que a investigação da ciência divina se volta para as primeiras causas das "existências naturais" ou "existências matemáticas", em outras palavras, nesta ciência se pesquisa as razões ou determinações primordiais, ou ainda a gênese, de todas as coisas naturais ou físicas e quantitativas que são objeto de estudo das duas outras classes das ciências teóricas ou especulativas e, consequentemente, de todas as demais ciências a estas relacionadas, ou por subdivisão, ou por depender daquilo que elas investigam; e, ainda, da razão e do princípio ou fundamento absoluto de tudo o que existe, que Avicena identifica com "o Deus excelso" 31.

Recordando o que observara em seu comentário aos Analíticos Posteriores de Aristóteles (isto é, nos livros referentes à Lógica), faz a seguinte afirmação: toda a ciência possui um objeto formal de investigação e cuja argumentação se dá a partir de certos princípios nela admitidos. Entretanto, segue Avicena, nada se afirmou com precisão qual

\footnotetext{
${ }^{30}$ Avicenna, op. cit., p. 2-3.

${ }^{31} \mathrm{Na}$ versão arábica se diz "Deus, exaltado seja ele", numa tradução literal. O "existente primordial" ou "princípio absoluto" para Avicena se trata do Deus da revelação corânica, considerado o criador de todas as coisas.
} 
é o objeto formal da Ciência Divina, isto é, se o primeiro princípio é algo subsistente, ou existente em si mesmo, e a consequente possibilidade de investigação de suas propriedades e ação; ou se a Ciência Divina possui outra finalidade. Tais questões serão tratadas pelo autor nos capítulos seguintes da obra em questão.

No que concerne à relação da "ciência divina" com a " primeira filosofia" e a "sapiência", Avicena recorda, ainda, o seguinte:

Et etiam iam audisti quod haec est philosophia certíssima et philosophia prima, et quod ipsa facit acquirere verificationem principiorum ceterarum scientiarum, et quod ipsa est sapientia certissime. Iam etiam audisti saepe quod sapientia est excellentior scientia ad sciendum id quod est excellentius scitum, et iterum quod sapientia est cognitio quae est certior et convenientior, et iterum quod ipsa est scientia primarum causarum totius. ${ }^{32}$

Também já ouviste que esta é a filosofia mais precisa e a primeira filosofia; que ela faz adquirir a verificação dos princípios de outras ciências e que ela é a mais precisa sapiência. Já ouviste também muitas vezes que a Sapiência é a mais excelente ciência para se instruir no mais excelente axioma; e ainda, que a Sapiência é o conhecimento mais preciso e conveniente e, ainda, ela é a ciência de todas as primeiras causas.

A Primeira Filosofia ${ }^{33}$ (e, no sentido até aqui exposto, poder-se-ia chamá-la de "Filosofia fundamental" ou "Filosofia dos fundamentos") é considerada a filosofia mais precisa em razão de, por ela, se verificar os fundamentos e premissas das demais ciências, que não podem - ou não consistem em seu objeto formal - demonstrar sua veracidade ou existência. Tais premissas podem ser consideradas evidentes per se ou evidentes per alia, isto é, se pertencem ao senso comum ou se são demonstráveis; no primeiro caso, são os axiomas, ou seja, as premissas necessárias e indemonstráveis; no segundo, é uma hipótese, se admitido pelo estudante, ou, caso contrário, um postulado. ${ }^{34}$ Sendo assim, a verificação das premissas axiomáticas, hipotéticas ou postuladas não se faz na própria ciência que as têm por princípio de argumentação, mas na Primeira Filosofia.

Avicena acrescenta ainda que esta ciência (a Primeira Filosofia ou Ciência Divina) é a mais precisa sapiência, isto é, o mais perfeito conhecimento contemplativo das coisas humanas e divinas, visto que, por meio dela, se atinge a inteligência das razões

\footnotetext{
${ }^{32}$ Avicenna, op. cit., p. 3.

${ }^{33}$ As expressões "filosofia", "primeira filosofia" e "sapiência" grafamos com inicial minúscula quando em sentido genérico e com inicial maiúscula quando em sentido específico ao denominar a ciência ou a parte da ciência referida.

${ }^{34}$ Cf. STORCK, op. cit., p. 271.
} 
primordiais de todas as coisas. Por meio dela, pode-se adquirir um conhecimento certo das verdades absolutas. Entretanto, ele acrescenta:

Et tamen non intellexisti quid esset haec philosophia vel haec sapientia, nec si haec três definitiones vel proprietates sint unius artis vel diversarum quarum unaquaeque dicatur sapientia. Nunc autem nos manifestabimus quod haec scientia in cuius via sumus est philosophia prima et quod ipsa est sapientia absolute, et quod tres proprietates per quas describitur sapientia, sunt proprietates unius magisterii, et quod ipsa est ipsum magisterium. ${ }^{35}$

Todavia, não compreendeste que era esta Filosofia, ou esta Sapiência, nem se estas três definições ou propriedades são de uma única arte, ou de diversas, das quais qualquer uma é chamada sapiência. Portanto, mostraremos agora que esta ciência, em cuja via estamos, é a primeira Filosofia, que ela própria é a absoluta Sapiência, que as três propriedades pelas quais a Sapiência é descrita são propriedades de um único magistério e que ela mesma é o próprio magistério.

Segundo Avicena, não estava claro naquelas afirmações que retoma se se tratava precisamente desta ciência em questão, a que se refere como "ciência intelectual", "ciência divina", "primeira filosofia" ou a "sapiência" par excellence; se ela constitui uma única arte ou ciência, como demonstrará a seguir, e não uma multiplicidade, como aparenta; se ela é, de fato, a Sapiência par excellence à qual se atribui as três definições ou propriedades descritas, a saber: a) é a mais excelente ciência para se instruir no mais excelente axioma; b) é o conhecimento mais preciso e conveniente; c) é a ciência de todas as primeiras causas; por fim, se esta ciência constitui um único magistério ou disciplina, como será demonstrado.

Avicena recorda que as ciências filosóficas são classificadas em dois grandes grupos: as ciências práticas ou ativas (ou, ainda, morais), que dizem respeito aos atos humanos, tanto individuais, como sociais; e as ciências teóricas ou especulativas (ou, ainda, contemplativas), que dizem respeito à cognição das coisas existentes. Estas se agrupam segundo os modos de percepção unidas à cosmovisão aviceniana, a saber: na percepção dos sensíveis, das quantidades e dos princípios incorpóreos e imateriais. Sendo assim, existem ciências do raciocínio, ciências das coisas naturais, ciências dos números, ou das coisas numéricas, e ciência das coisas inteligíveis.

\footnotetext{
${ }^{35}$ Avicenna, op. cit., p. 3-4.
} 
Ora, sobre esta última, não foi esclarecido ou definido qual é o objeto formal de sua pesquisa, se há mais de um e se trata de uma única ciência ou de um grupo com suas subdivisões, conforme seus respectivos objetos de investigação. Inclusive sua denominação não é certa, variando entre "ciências intelectuais", "ciência divina", "primeira filosofia" ou "sapiência" e se há uma sinonímia nessas qualificações ou indicação aspectual de uma mesma ciência. Sabe-se, ao menos, que ela trata da verificação dos princípios das demais ciências.

\section{I.3. A “Ciência Divina" é uma "Theo-logia” (filosófica)?}

Nos três parágrafos que seguem, o autor discute se Deus é o objeto de investigação da "ciência divina", como já foi proposto, procurando demonstrar a impossibilidade desse postulado e esclarecer sua argumentação. Vejamos o que ele diz:

Constat autem quod omnis scientia habet subiectum suum proprium. Inquiramus ergo quid sit subiectum huius scientiae, et consideremus an subiectum huius scientiae sit ipse Deus excelsus; sed non est, immo est ipse unum de his quae quaeruntur in hac scientia. Dico igitur impossibile esse ut ipse Deus sit subiectum huis scientiae, quoniam subiectum omnis scientiae est res quae conceditur esse, et ipsa scientia non inquirit nisi dispositiones illius subiecti, et hoc notum est es aliis locis. Sed non potest concedi quod Deus sit in hac scientia ut subiectum, immo est quaesitum in ea, scilicet quoniam, si ita non est, tunc non potest esse quin sit vel concessum in hac scientia et quaesitum in alia, vel concessum in ista et non quaesitum in alia. ${ }^{36}$

É certo que toda a ciência tem seu próprio objeto [de investigação]. Portanto, investiguemos qual é o objeto [de investigação] desta ciência e consideremos se o objeto [de investigação] desta ciência consiste no próprio Deus excelso; todavia, não é, pelo contrário, é o próprio uno das coisas que se pesquisa nesta ciência. Portanto, afirmo ser impossível que o próprio Deus seja o objeto [de investigação] desta ciência, porque o objeto [de investigação] de toda ciência é aquilo que se atribui existência; a própria ciência investiga tão somente as disposições daquele objeto e isto é conhecido alhures. Mas não se pode admitir que Deus seja o objeto [de investigação] desta ciência, pelo contrário, ele é uma questão tratada nela, porquanto, se não fosse assim, a existência [de Deus] não poderia ser admitida nesta ciência e uma questão em outra, ou ser admitida naquela e não uma questão em outra.

\footnotetext{
${ }^{36}$ Avicenna, op. cit., p. 4.
} 
Avicena levanta aqui algumas questões importantes. Procura, primeiramente, qual é o objeto de investigação da ciência filosófica em questão, a "ciência divina", e a possibilidade de este se tratar de Deus. Logo de partida, nega categoricamente este postulado, indicando que consiste no unum das coisas que nela se pesquisam, isto é, naquilo que há de comum a todas as coisas especuladas, ou seja, a sua existência. Como já foi dito anteriormente, nenhuma ciência filosófica especula a existência de seus princípios, em outras palavras, não verifica se seus princípios são reais, mas supõe isto necessariamente.

Caberia à Primeira Filosofia a função de verificar a existência das premissas das demais ciências. Sendo assim, Deus não pode ser o objeto de investigação desta ciência, pois então, dever-se-ia supor necessariamente sua existência, deixando para uma outra ciência a demonstração de sua existência. ${ }^{37}$ Esta verificação, a princípio, é atribuição desta filosofia e de nenhuma outra. Mas sigamos o raciocínio de Avicena:

Sed utrumque falsum est, quoniam impossibile est ut sit quaesitum in alia, eo quod aliae scientiae vel sunt morales vel civiles vel naturales vel doctrinales vel logicae, et nulla scientia sapientiae est extra hanc divisionem. In nulla autem earum quaeritur an sit Deus, quia non potest hoc esse ut in eis quaeratur, et tu scies hoc parva inspectione ex his quae multotiens inculcamos. Nec etiam potest esse ut non sit quaesitum in alia ab eis scientia: tunc enim esset non quaesitum in scientia ullo modo. Igitur aut est manifestum per se, aut desperatum per se quod non possit manifestari ulla speculatione. Non est autem manifestum per se, nec est desperatum posse manifestari, quia signa habemus de eo. Amplius: omne id cuius manifestatio desperatur, quomodo potest concedi esse eius? Restat ergo ut ipsum inquirere non sit nisi huius scientiae. ${ }^{38}$

Mas, as duas afirmações são falsas, porque é impossível que [Deus] seja uma questão em outra [ciência], por aquilo que outras ciências são ou morais, ou civis, ou naturais, ou doutrinais, ou lógicas e nenhuma ciência da sapiência está fora desta divisão. Porém, em nenhuma das ciências se questiona se Deus existe, porque isso não é possível à existência [de Deus] que se pesquisa nelas e tu sabes isto com pouco exame daquilo que com frequência apontamos. Também não é possível à existência [de Deus] que não seja uma questão em outra ciência derivada daquelas, pois, de

\footnotetext{
${ }^{37}$ Nesta lógica, deveria se supor, então, uma ciência superior à "primeira filosofia", que verificasse a existência de Deus a fim de que este se tornasse objeto de especulação. Nesse caso, a "primeira filosofia" deixaria de ser a primeira, havendo aqui uma contradição.

${ }^{38}$ Avicenna, op. cit., p. 4-5.
} 
qualquer modo, não seria uma questão na ciência. Portanto, ou se manifesta por si, ou se oculta por si, porque não pode ser manifestado por alguma especulação. Porém, o poder ser manifestado não se manifesta, nem se oculta por si, porque temos os indícios que provém dele. Além disso, tudo aquilo cuja manifestação se oculta, como pode se admitir a sua existência? Resta, porém, que o próprio investigar [sobre Deus] não seja senão desta ciência.

Avicena descarta a possibilidade de Deus e sua existência - que são questões axiomáticas, como já foi dito anteriormente - serem investigadas em outras ciências filosóficas, quer práticas, quer especulativas. Tudo o que já foi dito, segundo Avicena, a respeito da divisão das ciências (filosóficas) é o suficiente para perceber essa inconveniência, visto que, o que cada "ciência da sapiência"39 trata não coincide nem com Deus, sua existência ou seus atributos.

No que se refere à existência de Deus, Avicena afirma ser uma questão axiomática, ou é evidente per se, ou nos é simplesmente oculto. Se nos é oculto, é incognoscível, nada, portanto, podendo ser afirmado ou negado. No entanto, Avicena afirma que é possível reconhecer a existência de Deus a partir de indícios provenientes dele. A partir desses indícios, que são uma demonstração evidente per se de sua existência, segundo Avicena, pode-se, então, especular sobre Deus.

Notemos, ainda, de passagem, uma outra ordem na classificação das ciências: "por aquilo que outras ciências são ou morais, ou civis, ou naturais, ou doutrinais, ou lógicas e nenhuma ciência da sapiência está fora desta divisão". Não é uma citação aleatória, mas se apresenta numa ordem lógica, embora distinta do que até agora foi apresentado: inicia por duas ciências práticas, inferiores na tabela e referentes aos atos humanos, primeiro individual (moral ou ética), depois a social (civil ou política); em seguida, as especulativas ou teóricas, aquelas que se referem à reflexão do mundo, numa gradação ascendente, referentes à especulação dos acidentes corpóreos (naturais), das quantidades abstratas (doutrinais) e das ideias mentais (lógicas), incorpóreas, e que estão na razão humana.

Avicena continua afirmando:

De eo autem inquisitio fit duobus modis. Unus est quo inquiritur an sit, alius est quo inquiruntur eius proprietates; postquam autem inquiritur in hac scientia an sit, tunc non potest esse subiectum huius scientiae. Nulla enim scientiarum debet stabilire

\footnotetext{
${ }^{39}$ Aqui, "sapiência" está sendo usada em sentido genérico como equivalente à filosofia.
} 
esse suum subiectum. In próximo etiam ostendam quod an sit non potest quaeri nisi in hac scientia. ${ }^{40}$

A partir disso, a investigação se realiza de dois modos: primeiro, se [Deus] existe; segundo, sobre suas propriedades. Portanto, se esta ciência investiga se [Deus] existe, então, não pode a existência [de Deus] ser o objeto formal desta ciência. Pois, a nenhuma ciência convém estabelecer a existência [de Deus] como o seu objeto formal. A seguir, mostrarei também que, se [Deus] existe, não pode ser procurado a não ser nesta ciência.

Continuando, Avicena refere-se ao modo de se investigar sobre Deus, dividindoo em duas etapas: a) demonstração da existência de Deus a partir de seus indícios mencionados anteriormente, em outras palavras, trata-se das "provas racionais da existência de Deus"; b) as propriedades de Deus que podem ser daí deduzidas.

Sendo assim, Avicena conclui que se esta ciência procura comprovar a demonstrabilidade da existência de Deus a partir de seus indícios. Logo, a existência de Deus não pode ser seu objeto formal, recordando que "a nenhuma ciência convém estabelecer a existência [de Deus] como o seu objeto formal", ou seja, não é próprio de nenhuma ciência filosófica verificar a existência de Deus, pois isso não é possível e nem próprio a nenhuma delas, porquanto, segundo Avicena, Deus deve evidenciar-se por si mesmo, cabendo ao pesquisador reconhecer os seus vestígios que indicam sua existência e, a partir disso, especular sobre suas propriedades.

Avicena conclui esse ponto afirmando o seguinte:

Manifestum est enim ex dispositione huius scientiae quod ipsa inquirit res separatas omnio a matéria. Iam etiam significavit tibi in naturalibus quod Deus est non corpus nec virtus corporis, sed est unum separatum a materia et ab omni commixtione omnis motus. Igitur inquisitio de eo debet fieri in hac scientia, et quod de hoc apprehendisti in naturalibus erat extraneum a naturalibus quia quod de hoc tractabatur in eis non erat de eis, sed voluimus per hoc accelerare hominem ad tenendum esse primum principium, ut per hoc augeretur desiderium addiscendi scientias et perveniendi ad locum in quo certius possit cognosci. ${ }^{41}$

Pois, reconhece-se que, a partir da disposição desta ciência, ela própria investiga as coisas inteiramente separadas da matéria. Também já te fiz entender nas ciências naturais que Deus não é nem corpo, nem faculdade do corpo, mas é um separado da

\footnotetext{
${ }^{40}$ Avicenna, op. cit., p. 5.

${ }^{41}$ Idem, p. 5-6.
} 
matéria e de toda mistura com todo o movido. Portanto, deve-se realizar a investigação sobre ele nesta ciência. O que aprendeste sobre isto nas ciências naturais era-lhe estranho, porque não era algo a ser tratado por elas, mas quisemos antecipar isso a fim de que o homem perceba a existência do primeiro princípio, para que, através disso, fosse acrescido o desejo de aprender as ciências e de atingir um lugar no qual possa instruir-se com maior segurança.

Avicena já havia dito acima que "as ciências divinas investigam as coisas separadas da matéria segundo a subsistência e definição" 42 , afirmação que aqui recorda. Sendo assim, a "ciência divina" é a ciência apropriada para se especular sobre Deus, que não é corpóreo, mas separado da matéria e de seus movimentos. Em suma, Deus é objeto de investigação por aquilo que ele é em si mesmo, conhecimento que se obtém através de seus vestígios, e não na verificabilidade de sua existência que, como já foi dito, não é possível.

Avicena observa ainda que, o que havia sido dito a respeito de Deus nas ciências naturais, embora fosse algo estranho a essas disciplinas, seu intuito era familiarizar o estudante à apreensão da existência do primeiro princípio a fim de instigá-lo a progredir nos estudos filosóficos para adquirir um conhecimento mais seguro.

Portanto, a Ciência Divina ou Primeira Filosofia é a ciência filosófica que indaga a respeito das coisas sumamente abstratas e inverificáveis, porém necessárias per se, e verifica o princípio axiomático das demais ciências. Sendo assim, ela consiste numa ciência que especula sobre as "coisas existentes em si", ou melhor, as "coisas subsistentes", e, portanto, é uma ciência das realidades inteligíveis.

Desse modo, é nesta ciência que se efetua convenientemente uma especulação sobre Deus, mas a partir de seus vestígios que demonstram a sua realidade existencial porquanto sua existência não pode ser especulada em nenhuma ciência, por ser ela racionalmente inverificável em razão de seu sumo grau de abstração das realidades sensíveis.

Conclui-se disso que Deus e sua existência, ou subsistência, não é e não pode ser objeto de investigação da Ciência Divina, mas pode-se tratar sobre ele a partir de um aspecto seu comum a outras "coisas existentes" que também são indagadas na Primeira Filosofia, a saber: os existentes necessários (relativamente falando) e os primeiros

\footnotetext{
${ }^{42}$ Idem, p. 2.
} 
princípios de todas as coisas existentes. Nisto consiste o unum citado pelo autor: existentes reais e primordiais.

Portanto, a Ciência Divina ou Primeira Filosofia não se reduz a uma Theologia rationalis. A questão é se esta última está ou não inclusa naquela, ou se trata de uma outra categoria de ciência. Isto será discutido mais à frente.

A partir disso, o autor passa a indagar-se sobre as causas ( $\alpha \imath \tau 1 \alpha$, aitia) como objeto de investigação da Primeira Filosofia. Acompanhemos o seu raciocínio.

\section{I.4. A Primeira Filosofia (ou Sapiência) é uma "Aitio-logia"?}

Nos quatro últimos parágrafos deste capítulo que estamos estudando, o autor discute se o objeto de investigação da Primeira Filosofia consiste nas chamadas "últimas causas" (no sentido de "causas primordiais"), também conhecidas como as "quatro causas", quer em conjunto, quer uma delas em separado, como já fora proposto. Do mesmo modo que ocorreu em relação a Deus, o autor procura demonstrar ser isso inapropriado no que concerne à subsistência enquanto realidades inteligíveis.

Sigamos, portanto, o seu raciocínio:

Postquam autem necesse est ut haec scientia subiectum habeat, et monstratum est illud quod putabatur esse subiectum eius non esse suum subiectum, tunc quaeremus an subiectum eius sint ultimae causae eorum quae sunt, an omnes quattuor simul, non una tantum: sed hoc non debet dici, quamvis iam hoc quidam putaverunt. Nam consideratio de omnibus quattuor causis non potest esse quin sit de illis inquantum sunt causae absolutae, vel inquantum unaquaeque earum quattuor est illius modi qui proprius est sibi, scilicet ut consideratio de illis sit secundum quod uma est agens et alia patiens et illa alia est alliud, vel secundum quod fit ex coniunctione illarum. ${ }^{43}$

Portanto, é necessário que esta ciência tenha um objeto formal. Já se mostrou que o que se julgava ser o seu objeto formal, na verdade não é; então, procuramos saber se o seu objeto formal consiste nas últimas causas de tudo que existe, se todas as quatro simultaneamente, não somente uma; todavia, isto não deve ser afirmado, embora alguns já o pensaram. Pois, a consideração acerca das quatro causas não é possível à existência, a não ser que exista a partir delas na medida que possuem existência, ou enquanto sejam causas absolutas, ou na medida que cada uma das quatro é, desse modo, o que mais propriamente é em si mesmo, isto é, como a consideração acerca

\footnotetext{
${ }^{43}$ Idem, p. 6.
} 
delas esteja em conformidade em que uma seja agente, outra paciente e a terceira outra coisa, ou segundo o que se realizou a partir da conjunção delas.

Avicena continua a investigar o objeto formal da ciência em questão, afirmando que já foi demonstrado que Deus, que se supôs que fosse, não é. Propõe-se agora investigar se se trata das últimas causas (ultimae causae), isto é, das razões fundamentais de todas as coisas existentes, que são: causas materiais (matéria prima), causas formais (configuração), causas eficientes (determinador) e causas finais (finalidade); se é cada uma delas em conjunto e não uma delas em particular.

Segundo Avicena, já foi sugerido por outros que seriam as quatro causas em conjunto, fato que ele não considera possível pois, segundo ele, essas causas ou fundamentos deveriam ser subsistentes, isto é, possuírem existência em si mesmas ou serem causas absolutas; ou então, deveriam ser especuladas naquilo que são em si mesmas: uma como agente (causa eficiente), outra como paciente (causa material) e assim por diante. Desse modo, seriam especuladas em si mesmas e não como princípio das outras coisas existentes.

Sendo assim, ele segue:

Dico autem quod, si bene consideretur, non possunt esse subiectum huius scientiae inquantum sunt causae absolutae, ita ut intentio huius scientiae sit considerare ea quae accidunt causis inquantum sunt causae absolutae. Et hoc patet multis modis, quórum unus est scilicet quod haec scientia inquirit intentiones quae non sunt ex accidentibus propriis ipsarum causarum inqunatum sunt causae. Inquirit enim universale et particulare, potentiam et effectum, possibile et necesse, et cetera. Manifestissimum est autem quod haec tália sunt in se quod inquisitivo debet fieri de illis, nec sunt ex accidentibus quae sunt própria rebus naturalibus nec doctrinalibus, nec cadunt inter accidentia quae sunt própria scientiarum practicarum. Restat igitur ut perquisitio sit de illis in scientia quae est extra praedictam divisionem, et illa est haec scientia. ${ }^{44}$

Afirmo também que, se bem considerado, não podem ser [as causas] o objeto formal desta ciência enquanto são causas absolutas, assim como a intenção desta ciência seja considerar aquilo que ocorre às causas enquanto são causas absolutas. Isto se evidencia de muitos modos, dos quais um é, evidentemente, que esta ciência investiga as intenções que não procedem dos acidentes mais específicos das próprias causas enquanto são causas. Porém, investiga o universal e o particular, a potência e

\footnotetext{
${ }^{44}$ Idem, p. 6-7.
} 
o efeito, o possível e o necessário e outros. Além disso, é reconhecidíssimo que estes existam por si mesmos, porquanto a investigação deve ser feita sobre eles, os quais não provém de acidentes que são próprios das coisas naturais, nem das doutrinais, nem recaem entre os acidentes que são próprios das ciências práticas. Portanto, resta que exista uma pesquisa sobre eles nesta ciência em questão não mencionada na divisão anterior.

Considerando que a Primeira Filosofia consiste numa ciência que especula sobre as coisas existentes em si mesmas, ou as coisas subsistentes, e não sobre seus acidentes, isto é, suas qualidades contingentes que lhe são acrescidas (quantidade, extensão e outros), que dependem delas, Avicena descarta a possibilidade de as causas serem objeto de investigação desta ciência, visto que poderiam somente ser especuladas enquanto “causas absolutas", ou seja, enquanto razões subsistentes.

Contudo, a subsistência não é inerente às "quatro causas", enquanto são causas (em seu conjunto), visto que a configuração (causa formal) e a finalidade (causa final), por exemplo, não serem existentes reais em si mesmos, mas uma qualidade acrescida à "matéria prima" (causa material) que, por sua vez, pode ser simplesmente mera possibilidade de ser e não um existente real em si mesmo (na qualidade de causa material). Quanto à causa eficiente, ou o determinador, a subsistência lhe é inerente ao tratar-se do princípio absoluto ou primeiro princípio.

Sendo assim, Avicena afirma que a investigação desta ciência se dirige ao universal e ao particular, potência e efeito, possível e necessário e outros, coisas essas que, segundo o autor, "existem por si mesmos", não sendo derivantes de acidentes de coisas naturais, matemáticas ou próprias das ciências práticas (morais) e, portanto, próprias a serem investigadas pela Primeira Filosofia.

Avicena continua:

Et etiam quia scientia de causis absolute acquiritur post scientiam qua stabiliuntur causae rerum causas habentium: dum enim nos non stabilierimus esse causarum causatarum a rebus aliis, sic ut esse earum pendeat ex eo quod praecedit in esse, non sequetur apud intellectum esse causae absolutae, sed hic est causa una; quamvis sensus inducat ut duae causae concurrent, sed licet concurrant, non minus tamen debet esse una causa alterius: persuasio enim quae adveniat animae ex assiduitate sensus et experientiae non est cogens, sicut scisti, nisi per cognitionem quod in pluribus ex rebus quae sunt naturales et electionis contingit hoc. Et hoc certe est appositum ad stabiliendum causas: concedere enim essas causas et occasiones non 
est manifestum primum, sed probabile; iam autem scisti differentiam inter haec duo. Nam non si paene fuerit manifestum per se apud intelligentiam quod quicquid coepi habet principium aliquod, ideo debet esse manifestum per se, sicut multa ex rebus geometricis per quae probantur cetera in libro Euclidis, deinde manifestatio demonstrativa non est ita in ceteris scientiis: unde debet esse in hac scientia. Quomodo igitur potest esse ut illud sit subiectum scientiae inter inquisitiones quaerantur dispositiones eius cuius esse est quaesitum in ea? ${ }^{45}$

Mesmo porque, a ciência das causas se adquire com perfeição após a ciência pela qual se estabelecem as causas das coisas que possuem causas. Com efeito, enquanto não estabelecemos a existência das causas causadas a partir de outras coisas, assim como a existência delas depende daquilo que precede na existência, não se segue ao intelecto a existência de uma causa absoluta, mas aqui está a causa una. E ainda que o sentido induza que duas causas coincidam, mesmo assim, não é forçoso que uma seja a causa de outra, pois, a convicção que chega à alma procedente da frequência do sentido e da experiência não é congregante, como já sabes, a não ser através do conhecimento que vem da variedade das coisas que são naturais, atingindo isso pela escolha. E isto certamente é apropriado para o estabelecimento das causas, pois, admitir que existem as causas e ocasiões não se reconhece primeiramente, mas como provável; porém, já sabes a diferença entre essas duas. Pois, quase não se foi reconhecido por si no intelecto que qualquer coisa que comece, tenha algo por princípio; por essa razão, convém que a existência [de Deus] se manifeste por si, assim como muitas das realidades geométricas pelas quais outras são verificadas no livro de Euclides, e depois, o reconhecimento demonstrativo não é assim em outras ciências, por isso [especular sobre] a existência [de Deus] convém a esta ciência. Portanto, como pode a existência [de Deus] ser o objeto formal entre as pesquisas cujas disposições são procuradas e cuja existência [de Deus] é uma questão nela?

Não sendo as causas acima descritas "causas absolutas" (ou razões subsistentes), não convém que elas sejam investigadas pela Primeira Filosofia, mas é necessário que se estabeleçam as causas (os fundamentos) de todas as coisas que não possuem subsistência, isto é, não existem em si mesmas simplesmente, então, ao conhecer os fundamentos ou razões das quatro causas em questão, possa se adquirir com perfeição o seu conhecimento. Desse modo, poder-se-á, então, atingir a ciência da causa absoluta, ou seja, do fundamento primordial ou razão última de todas as coisas, que consiste na "causa una".

\footnotetext{
${ }^{45}$ Idem, p. 7-8.
} 
Se a apreensão pelos sentidos sugere a "coincidência" de duas causas, isto é, que uma procede da outra, não é certo que assim ocorra, visto que a apreensão pelos sentidos por si só não é capaz de atingir tal conhecimento com precisão por não possuir a abrangência de todos os fatores que compõem as coisas naturais e cujas relações só podem ser distinguidas pelo processo de operação abstrativa do intelecto podendo admitir (ou não) algo como princípio e outro como seu efeito. Porquanto o intelecto não admite $a$ priori que tudo que se origina possui necessariamente um princípio e, consequentemente, que a existência de uma causa consiste numa probabilidade.

Sendo assim, fica claro que a existência de um princípio absoluto não seja demonstrável por si mesmo, senão em seus efeitos, e portanto, faz-se necessário que a existência de Deus seja manifestada por si mesma, do mesmo modo como ocorre com certas formas geométricas (como, por exemplo, o círculo) apresentadas no livro de Euclides, como Avicena exemplifica. Ora, nas outras ciências, a demonstração não acontece desse modo; por essa razão, a Primeira Filosofia é a ciência adequada para se especular sobre a existência de Deus, não propriamente como seu objeto formal, mas como uma questão referente à especulação dos primeiros princípios.

Avicena conclui o primeiro capítulo sintetizando sua ideia:

Quod cum ita sit, manifestum est quod non est inquisitio de illis etiam inquantum unaquaeque earum habet esse proprium, ut hoc sit quaesitum in hac scientia, nec est etiam inquantum sunt coniunctio aliqua et omnio, non dico coniunctum nec universale, eo quod consideratio de partibus coniunctionis prior est quam consideratio de coniunctione, quamvis non sit ita in particularibus univeralis secundum respectum quem nosti. Unde oporteret haberi considerationem de partibus, sed vel in hac scientia, et tunc conveniens esset eas esse subiectum eius, vel in alia: sed in alia scientia esse non potest. Nulla enim alia inquirit de causis ultimis nisi ista scientia. Si autem consideratio de causis fuerit inquantum habent esse et de omni eo quod accidit eis secundum hunc modum, oportebit tunc ut ens, inquantum est ens, sit subiectum, quod est convenientius. Monstrata est igitur destrictio illius opinionis qua dicitur quod subiectum huius scientiae sunt causae ultimae, sed tamen debes scire quod haec sunt completio et quaesitum eius. ${ }^{46}$

Porquanto é manifesto que, assim como não se trata de uma pesquisa referente às causas, caso cada qual possuísse existência própria - neste sentido, então, tratar-seia tão somente de uma questão nesta ciência -, nem tampouco por possuírem alguma

\footnotetext{
${ }^{46}$ Idem, p. 8-9.
} 
ligação entre si parcial ou totalmente, não digo de modo inerente ou universal, pelo fato de a consideração sobre as partes da ligação precede a [própria] consideração da ligação, embora isso não ocorra nas partes de um todo, segundo o que observamos e conhecemos. A partir disso, convém que consideremos sobre as partes; entretanto, que isto ou se faça nesta ciência, e então, ser-lhe-ia conveniente que a existência fosse seu objeto [de investigação], ou [se faça] em outra [ciência], mas, em outra ciência, não é possível que a existência [seja seu objeto de investigação].

Portanto, não há outra ciência na qual se pesquise sobre as últimas causas a não ser esta. Todavia, se houvesse uma consideração sobre as causas na condição de possuírem existência e sobretudo que se lhes ocorre segundo este modo, convirá então que o existente, enquanto é um existente, seja objeto formal, o que é mais conveniente. Portanto, mostra-se a refutação daquelas opiniões que afirmam serem o objeto formal desta ciência as últimas causas, mas, todavia, deves saber que estas coisas são o acabamento e sua questão.

Sintetizando o que foi dito: após haver demonstrado que Deus não pode ser objeto de investigação da Ciência Divina, o autor levanta o postulado de alguns - que ele não explicita quem - de serem as últimas causas aquilo que esta ciência - a Primeira Filosofia - trata; portanto, tratar-se-ia de uma Etiologia, ou "ciência das causas" (fundamentais).

Entretanto, Avicena refuta este postulado recordando que a ciência em questão trata de coisas existentes em si mesmas, ou então, de coisas subsistentes e, portanto, as últimas causas deveriam ser realidades subsistentes, substâncias individuais, o que, de fato, não são e nem podem ser, porquanto, de modo geral, são realidades acidentais acrescidas às substâncias.

Por conseguinte, a Primeira Filosofia trataria de coisas subsistentes e primordiais como, segundo o autor, o universal e o particular, potência e efeito, possível e necessário, que seriam realidades subsistentes e não dependentes ou acidentais de coisas tratadas pelas outras ciências já citadas.

Ora, como esta ciência busca verificar os fundamentos daquilo que as outras ciências investigam, então ela verifica o princípio absoluto das "causas" ou a causa das causas; sendo assim, as causas são investigadas não em si mesmas, mas como princípios de outras coisas numa sequência que retrocede até a causa absoluta ou causa una, o existente necessário e primordial. 
Portanto, investigação sobre as causas não consiste no objeto de pesquisa da Primeira Filosofia, mas é uma das questões tratadas por ela e, como Avicena diz concluindo o capítulo, o seu coroamento.

\section{I.5. Recapitulação geral}

A constatação da necessidade de se estabelecer uma "nova" ciência filosófica se faz a partir da análise do sistema orgânico pelo qual se relacionam todas as demais ciências entre si mediante o seu "campo de investigação". Ora, isso se faz segundo uma ordenação das coisas existentes e das percepções que se fazem delas. Para tanto, Avicena retoma brevemente a classificação das ciências indicando brevemente seus respectivos campos de investigação.

Todavia, ao fazer isso, o autor propõe algumas alterações no modo clássico de se categorizar as ciências filosóficas, que, a princípio, ele mesmo segue, a saber, o esquema peripatético, em vista de delimitar o campo de estudo desta nova ciência filosófica seguindo os graus de conhecimento abstrativo, que vai da percepção das coisas acidentais existentes nos corpos, até as coisas inteligíveis totalmente abstraídas da matéria.

Nesse sentido, podemos constatar duas notáveis mudanças: a primeira é a consideração da Lógica, não mais simplesmente como um organon ou instrumento que capacita a faculdade racional de realizar o seu processo de intelecção, mas constituindo uma ciência filosófica especulativa, a primeira em sentido ascendente, precedendo as naturais ou físicas. $\mathrm{O}$ autor indica discretamente isso, embora ainda não mencione nada a respeito de qual seja seu campo de investigação.

Levando-se em conta isso, podemos estabelecer provisoriamente a seguinte tabela referente à divisão das ciências, segundo Avicena:

\begin{tabular}{|c|c|c|l|}
\hline \multicolumn{4}{|c|}{ Classificação das Ciências Filosóficas I } \\
\hline \multirow{4}{*}{ Estrutura orgânica } & \multicolumn{1}{c|}{ Campo de investigação } \\
\hline \multirow{4}{*}{$\begin{array}{c}\text { Ciências } \\
\text { especulativas } \\
\text { (teóricas) }\end{array}$} & Média & $\begin{array}{c}\text { Ciências } \\
\text { Intelectuais }\end{array}$ & $\begin{array}{l}\text { Aplica-se ao conhecimento teórico das coisas } \\
\text { Ciências } \\
\text { separadas da matéria segundo a subsistência e } \\
\text { definição. }\end{array}$ \\
\cline { 2 - 5 } & Inferior & $\begin{array}{l}\text { Aplica-se ao conhecimento teórico das } \\
\text { quantidades dos corpos segundo sua definição e } \\
\text { distinto dos aspectos acidentais e materiais dos } \\
\text { corpos. }\end{array}$ \\
\cline { 2 - 5 } & Racional & $\begin{array}{c}\text { Ciências } \\
\text { Lógicas }\end{array}$ & $\begin{array}{l}\text { Aplica-se ao conhecimento teórico dos corpos no } \\
\text { que se refere ao movimento e suas qualidades } \\
\text { acidentais. }\end{array}$ \\
\hline
\end{tabular}




\begin{tabular}{|c|c|l|}
\hline $\begin{array}{c}\text { Ciências } \\
\text { Ativas (práticas) }\end{array}$ & $\begin{array}{c}\text { Ciências } \\
\text { Morais }\end{array}$ & $\begin{array}{l}\text { Aplica-se ao conhecimento prático das ações } \\
\text { humanas. }\end{array}$ \\
\hline
\end{tabular}

Contudo, no decorrer do discurso, notamos uma segunda mudança: as ciências lógicas tomam um novo lugar na ordem das ciências, passando a serem numeradas após às ciências doutrinais ou matemáticas, em sentido ascendente, o que indica que as ciências lógicas, em seu campo de investigação, possuem um grau de abstração maior que as matemáticas, dando um passo às abstrações absolutas das ciências intelectuais.

Sendo assim, podemos estabelecer, também provisoriamente, fundando-nos em informações acrescidas posteriormente no texto em questão, a seguinte tabela da classificação das ciências filosóficas, segundo Avicena ${ }^{47}$ :

\begin{tabular}{|c|c|c|c|}
\hline \multicolumn{4}{|c|}{ Classificação das Ciências Filosóficas II } \\
\hline \multicolumn{3}{|c|}{ Estrutura orgânica } & Campo de investigação \\
\hline \multirow{4}{*}{$\begin{array}{l}\text { Ciências } \\
\text { especulativas } \\
\text { (teóricas) }\end{array}$} & Superior & $\begin{array}{l}\text { Ciências } \\
\text { Intelectuais }\end{array}$ & $\begin{array}{l}\text { Aplica-se ao conhecimento teórico das coisas } \\
\text { separadas da matéria segundo a subsistência e } \\
\text { definição e da verificação dos princípios das } \\
\text { demais ciências filosóficas. }\end{array}$ \\
\hline & Racional & $\begin{array}{l}\text { Ciências } \\
\text { Lógicas }\end{array}$ & (nada referido) \\
\hline & Média & $\begin{array}{l}\text { Ciências } \\
\text { Doutrinais }\end{array}$ & $\begin{array}{l}\text { Aplica-se ao conhecimento teórico das } \\
\text { quantidades dos corpos segundo sua definição e } \\
\text { distinto dos aspectos acidentais e materiais dos } \\
\text { corpos. }\end{array}$ \\
\hline & Inferior & $\begin{array}{l}\text { Ciências } \\
\text { Naturais }\end{array}$ & $\begin{array}{l}\text { Aplica-se ao conhecimento teórico dos corpos no } \\
\text { que se refere ao movimento e suas qualidades } \\
\text { acidentais. }\end{array}$ \\
\hline \multicolumn{2}{|c|}{$\begin{array}{l}\text { Ciências Ativas } \\
\text { (práticas) }\end{array}$} & $\begin{array}{l}\text { Ciências } \\
\text { Morais }\end{array}$ & $\begin{array}{l}\text { Aplica-se ao conhecimento prático das ações } \\
\text { humanas individuais (ética) e sociais (política). }\end{array}$ \\
\hline
\end{tabular}

No que se refere às ciências intelectuais, Avicena a denomina ora por Primeira Filosofia, ora por Ciência Divina, ora por Sapiência (par excellence), deixando claro que seu campo de investigação se dirige para as coisas absolutamente abstratas, embora não defina precisamente qual seja seu objeto formal. Uma de suas funções é a verificação dos princípios das outras ciências, por exemplo, o estudo das causas, sobretudo das últimas causas, que são estudadas nesta ciência, embora não sejam elas precisamente seu objeto formal.

\footnotetext{
${ }^{47} \mathrm{Na}$ subdivisão das especulativas em superior, média e inferior, por falta de uma nomenclatura apropriada, provisoriamente, também, usamos a denominação racional para as ciências lógicas. A questão será aprofundada no segundo capítulo, quando Avicena tratar do objeto formal da Lógica. Quanto às ciências ativas, não acrescemos nada ao que o autor tenha mencionado neste capítulo, embora possamos conhecer facilmente por outras fontes. Mas, como dito, são tabelas provisórias.
} 
Também o postulado de que Deus seja o objeto de pesquisa desta ciência está descartado, visto que a existência de Deus não pode ser verificada por nenhuma ciência, e para ser especulado por esta ciência em questão, deveria ter sua existência como certa e, para tanto, isso necessitaria de um reconhecimento mediante seus vestígios e, portanto, como causa absoluta de todas as coisas. Desse modo, Deus passa ser uma questão a ser tratada nesta ciência, mas não o seu objeto de pesquisa.

As últimas causas não podem ser consideradas objetos de investigação por não serem realidades existenciais em si mesmas, mas especuladas tão somente em vista de serem buscados os fundamentos das coisas existentes. De modo que a esta ciência se deve buscar as coisas absolutamente existentes e incorpóreas, totalmente desligadas da matéria.

Sendo assim, uma "teologia racional" e uma "etiologia" seriam subdivisões dessa ciência, ou as ciências intelectuais seriam um conjunto de ciências como as naturais ou matemáticas. Isso será especulado nos capítulos seguintes da obra de Avicena. 


\section{Capítulo II:}

\section{A determinação do objeto formal da Primeira Filosofia}

Neste segundo capítulo de nossa pesquisa, discorrer-se-á como o autor procura delimitar o objeto formal da Primeira Filosofia ou Ciência Divina, se este consiste em um único ou em mais de um e, consequentemente, se esta ciência filosófica se constitui em partes distintas. Para tanto, o autor repassará comentando brevemente sobre os objetos formais das demais ciências filosóficas, preparando o ambiente para a delimitação do objeto da ciência em questão.

O segundo capítulo do Liber de Philosophia Prima sive Scientia Divina Tractatus Primus, "Livro referente à Primeira Filosofia ou Ciência Divina - Primeiro Tratado", vem intitulado De stabiliendo subiectum huius scientiae, cuja tradução literal é “Sobre o estabelecimento do 'assunto' desta ciência”. Levando em consideração o que já foi exposto no início do capítulo anterior, traduzimos do seguinte modo: "O estabelecimento do objeto formal desta ciência". ${ }^{48}$ Sendo assim, passemos à percepção da estrutura argumentativa do capítulo. ${ }^{49}$

\section{II.1 Estrutura argumentativa}

No capítulo em questão, podemos perceber a sequência de seis pontos:

a) Uma retomada do objeto formal das ciências filosóficas anteriores:

Aspectos do corpo como objeto formal das ciências naturais;

$\checkmark$ A medida e o número (na matéria e separado da matéria) como objeto formal das ciências "matemáticas";

$\checkmark$ As primeiras e segundas intenções como objeto formal das ciências lógicas;

b) Considerações sobre a especulação referente à "substância" e "existência":
$\checkmark$ Geral
$\checkmark$ Numérica
$\checkmark$ Figura e lógica

\footnotetext{
${ }^{48} \mathrm{O}$ adjunto de argumento do latim (preposição de + ablativo) cuja tradução didática é "sobre", "a respeito de", supondo um liber, capitulum, tractatus etc., não se faz necessário em ser vertido para o português que, no caso, seria um latinismo.

${ }^{49}$ Não é necessário esclarecer que esta estrutura é uma percepção feita a partir da leitura que fazemos (da lógica interna que percebemos do raciocínio do autor) e a propomos de maneira didática a fim de facilitar o estudo do texto aviceniano, mas que não se apresenta de modo absoluto e fechado para outras perspectivas.
} 
c) A existência como unidade das "coisas" especuladas nas várias ciências;

d) O "existente" como objeto formal de investigação;

e) A divisão desta nova ciência filosófica em partes;

$\checkmark$ As partes ou divisões da Primeira Filosofia;

$\checkmark$ As últimas causas, o primeiro princípio e Deus como objeto de investigação;

f) Comparação da Primeira Filosofia com a Tópica e a Sofística.

Desenvolvamos estes tópicos:

No primeiro ponto, o autor encaminha o leitor para o raciocínio que leva a delimitar sem equívoco o objeto formal da ciência em questão, partindo da especificação do objeto formal das outras ciências filosóficas: naturais, enquanto repouso e movimento; matemáticas, enquanto relaciona quantidade e medida com a matéria ou separada dela, resultando em quatro principais ciências matemáticas; a Lógica, enquanto desenvolve o raciocínio pela percepção das “intenções” à intelecção das coisas existentes.

No segundo ponto, explana-se sobre objeto formal desta ciência em questão que constitui nas "coisas existentes", ou que possuem existência em si separadas da matéria ou incorpóreas e nas substâncias quer sejam corpóreas ou não, mas abstraindo de seus acidentes e focando o aspecto de sua substancialidade.

No terceiro ponto, é demonstrado que a existência, ou a "intenção de existir", é o que consiste no uno das coisas a serem especuladas nas demais ciências, ou seja, todas têm em comum o fato de possuírem existência, ou serem existentes.

No quarto ponto, argumenta-se a razão de ser os existentes em si mesmos como objetos de investigação desta ciência, enquanto são princípios para as outras ciências e não pretende investigar o princípio dos existentes abordados na Primeira Filosofia.

No quinto ponto, Avicena demonstra que a Primeira Filosofia ou Ciência Divina é dividida em partes, visto que é a ciência dos existentes, investiga os mesmos em suas diversas condições: como causas de outros existentes, como princípio das outras ciências, como realidades separadas da matéria e como princípio absoluto, que é identificado com a divindade.

No último ponto, Avicena faz uma comparação entre a Primeira Filosofia e duas divisões da Lógica, isto é, a Tópica e a Sofística, naquilo que possuem em comum e naquilo que se diferenciam.

Passemos agora à análise do segundo capítulo da obra aviceniana. 


\section{II.2. Uma retomada do objeto formal das ciências filosóficas anteriores}

Avicena principia o segundo capítulo tencionando delimitar precisamente o objeto formal da Primeira Filosofia, bem como a sua finalidade, partindo dos objetos formais das demais ciências e indicando a insuficiência do número de ciências filosóficas para abordar outros assuntos que as conhecidas não tratam.

Sendo assim, ele inicia, dizendo:

Oportet igitur ut monstremus quid sit subiectum huius scientiae sine dubio, ad hoc ut pateat nobis quae sit intentio huius scientiae.

Dico autem quod suum subiectum scientiae naturalis est corpus, non inquantum est ens, nec inquantum est substantia, nec inquantum est compositum ex suis duobus principiis, quae sunt hyle et forma, sed inquantum est subiectum motui et quieti. Scientiae vero quae sunt sub scientia naturali remotiores sunt ab hoc, similiter et Morales. ${ }^{50}$

Portanto, convém que indiquemos sem equívoco qual é o objeto formal desta ciência e que nos seja evidente qual é a intenção desta ciência. Afirmo que o objeto [de investigação] da ciência natural é o corpo, não enquanto é um existente, nem uma substância, ou um composto a partir de seus dois princípios, que são a hylé e a forma, mas enquanto está sujeito ao movimento e ao repouso. De fato, as ciências que estão sob a ciência natural estão mais distantes disto, de modo semelhante as [ciências] morais.

Neste parágrafo, é-nos elucidado, de modo bem claro, a distinção que fizéramos no início do capítulo anterior entre "objeto material" e "objeto formal" de uma ciência. Aplicando essa distinção àquela feita pelo autor no presente texto, o "objeto material" das ciências naturais (ou físicas) consiste no corpo, ou em qualquer realidade corpórea. Todavia, às ciências naturais não importa o corpo em sua condição de um existente simplesmente, porquanto o fato de um corpo existir é um pressuposto necessário a tais ciências. A sua condição de existente enquanto corpo, ou realidade corpórea, é de interesse de outra ciência (no caso, da Primeira Filosofia).

Do mesmo modo, não importa às ciências naturais especular a substancialidade dos corpos e o fato de estes serem uma composição de dois elementos primordiais segundo a doutrina peripatética -, a saber: a hylé e a forma. Estes dois princípios correspondem a duas das quatro primeiras causas, "matéria prima" ou causa material e

\footnotetext{
${ }^{50}$ Avicenna, op. cit., p. 9.
} 
"configuração" ou causa formal. Convém notar que o autor curiosamente preserva o termo grego original, hylé, que literalmente significa "madeira", e é entendido como base para, por exemplo, um escultor imprimir uma determinada forma, dar uma configuração. Os filósofos antigos utilizaram essa imagem do "escultor" e deram ao termo hylé o sentido de "matéria básica" ou "informe" apta a receber uma determinação (uma forma). ${ }^{51}$

No caso das ciências naturais, o que importa na investigação dos corpos são o seu aspecto do movimento ou do repouso; evidentemente, não no sentido comum de deslocamento, de mudança de lugar, mas, sim, de mudança, de alteração de estado, por exemplo, no movimento da água em processo de congelamento até tornar-se gelo, ou de aquecimento até converter-se em vapor.

As demais ciências dependentes das naturais (como é o caso da Medicina ou da Alquimia) especulam outros aspectos do corpo e, portanto, estão bem distantes da questão da substancialidade corpórea, de sua composição elementar primordial ou mesmo de sua condição existencial. O mesmo se dá com as ciências morais.

Na sequência, Avicena trata das quantidades abstratas que são especuladas pelas ciências matemáticas que se subdividem em quatro ramos, dos quais ele faz uma breve descrição:

Subiectum vero scientiae doctrinalis est mesura, sive intellecta absque matéria sive intellecta in matéria, et numerus, sive intellectus absque matéria sive intellectus in matéria. Non enim inquirit stabilire an mensura vel numerus intelligatur absque matéria vel in matéria, sed consideratio de his est de dispositionibus eorum quae accidunt eis post positionem eorum huiusmodi. Scientiae vero quae sunt sub discplinalibus, convenientius est ut non considerent nisi de accidentalibus consequentibus posita, quae sunt minus communia quam ipsa posita. ${ }^{52}$

O objeto formal da ciência doutrinal [matemática] é a medida, quer a percebida sem a matéria [Astronomia], quer a percebida na matéria [Geometria]; e o número, quer percebido sem a matéria [Aritmética], quer percebido na matéria [Música]. Pois, não se pretende estabelecer se a medida ou o número se percebe sem a matéria ou na matéria, mas a consideração destes é sobre as suas disposições que lhes ocorrem do mesmo modo após a posição deles. De fato, as ciências que estão sob as [ciências] disciplinares [matemáticas], convém melhor que não examinem a não ser sobre os acidentes resultantes dispostos, que são menos comuns que os próprios dispostos.

\footnotetext{
${ }^{51}$ Seguindo a mesma ideia, o latim usou a palavra materia, "madeira", com o mesmo sentido, de modo que as línguas românicas herdaram por via popular a derivação materia > "madeira", e por via erudita materia > "matéria".

${ }^{52}$ Avicenna, op. cit., p. 9-10.
} 
As ciências matemáticas tratam da quantidade abstrata que não existe como substância real em si mesma, mas constitui uma percepção dimensional linear quantitativa realizada no intelecto referindo-se tanto ao contínuo, como ao descontínuo dos corpos; portanto, tendo um grau de abstração, depende das realidades corpóreas ou materiais. Sendo assim, são consideradas ciências médias, acima das ciências especulativas inferiores ou naturais.

As que tratam das quantidades contínuas, grandezas ou medidas, são duas: a que se realiza na matéria, ou seja, nos corpos imóveis, como a Terra: é a Geometria; a que se realiza sem a matéria, isto é, pela observação distante de corpos móveis, como as esferas cósmicas: é a Astronomia.

As que tratam das quantidades descontínuas, plural ou numérica, são duas: aquela que se realiza na matéria, ou são relativas aos corpos, como duplo, metade, terço: é a Música (conforme a concepção antiga); aquela que se realiza sem a matéria, ou os números absolutos, as unidades (como o um, dois, três): é a Aritmética. ${ }^{53}$

A finalidade das ciências matemáticas não é se a percepção quântica se faz com ou sem a matéria, mas considerar suas disposições (dos corpos) conforme sua posição ou situação.

De fato, as ciências lógicas consistem em ciência do raciocínio e se voltam para o processo de intelecção. Elas são justamente apresentadas não propriamente como ciência filosófica, especulativa ou ativa, mas num método de raciocínio ou numa regulação do raciocinar e, portanto, em um propedêutico à filosofia. Aqui, Avicena apresenta como uma ciência racional com o seu próprio objeto formal a ser especulado e dentro da classificação das ciências teóricas, contudo, numa ordem diferente da que inferimos no capítulo anterior.

Vejamos o que Avicena diz a respeito da Lógica:

Subiectum vero logicae, sicut scisti, sunt intentiones intellectae secundo, quae apponuntur intentionibus intellectis primo, secundum hoc quod per eas pervenitur de cógnito ad incognitum, non inquantum ipsae sunt intellectae et habent esse intelligibile, quod esse nullo modo pendet ex matéria, vel pendet ex matéria, sed non corpórea. Non fuerunt autem aliae scientiae praeter eas. ${ }^{54}$

\footnotetext{
${ }^{53}$ Cf. Hugo de São Vítor, Didascalicon. Da Arte de ler. Petrópolis: Ed. Vozes, 2001, p. 93-95.

${ }^{54}$ Avicenna, op. cit., p. 10.
} 
O objeto formal da Lógica, como sabes, são os conceitos conhecidos [intentiones intellectae $]^{55}$ em segundo lugar, que são apresentados pelos conceitos conhecidos [intentiones intellectae] em primeiro lugar ${ }^{56}$, conforme isto que por elas chega do conhecido ao incógnito, não enquanto elas são percebidas e possuem existência perceptível, porque de modo algum a existência depende da matéria, ou depende da matéria, mas não corpórea. Porém, não houve outras ciências além dessas apresentadas.

Portando, o objeto formal da Lógica consiste nos conceitos conhecidos a partir de um primeiro conceito, um pré-conceito, através de um processo de raciocínio "lógico", silogístico, levando ao conhecimento a partir de coisas pré-concebidas às coisas até então ignoradas. Esse conhecimento, contudo, segundo Avicena, não se realiza a partir da percepção de coisas existentes corpóreas.

Se levarmos em conta o grau de abstração das coisas perceptíveis corpóreas, parece-nos aqui que Avicena coloca as ciências lógicas num grau superior às ciências matemáticas, segundo o processo interior do raciocínio, mais abstrato do que as ciências das quantidades numéricas, destoando do modo tradicional que se faz a classificação das ciências na qual a Lógica é apresentada como um instrumental às ciências filosóficas.

Isso nos parece ainda mais claro na afirmação seguinte: "porque de modo algum a existência depende da matéria, ou depende da matéria, mas não corpórea; porém, não houve outras ciências além dessas apresentados", que induz a buscar outras ciências que tratem das coisas abstraídas da matéria corpórea e, portanto, para a ciência metafísica ou das coisas inteligíveis, que seria um grau a mais das ciências lógicas, seguindo a ordem retomada aqui: ciências naturais, matemáticas, lógicas e metafísicas.

Ao apresentar os respectivos objetos formais que as ciências filosóficas especulativas ou teóricas investigam, Avicena nos parece propor uma classificação das ciências filosóficas um pouco distinta da que tínhamos inferido no capítulo anterior (lógicas, naturais, doutrinais e intelectuais). Esta classificação segue o grau de abstração

\footnotetext{
${ }^{55}$ Avicena define categoricamente o objeto formal da Lógica como as intentiones intellectae secundo. Aqui estamos diante de uma expressão cuja tradução é bem delicada. Até aqui, o termo intentiones há sido traduzido por "intenção" com o sentido de "finalidade", "propósito". Todavia, aqui não carrega esse sentido. No latim clássico, intentio pode significar também "premissa silogística" e, consequentemente, "ideia" (na qual se funda um raciocínio). Sendo assim, intentiones intellectae pode ser traduzida por "ideias compreendidas" ou "concebidas" e, portanto, "conceitos conhecidos", como optamos.

${ }^{56}$ As formas secundo e primo consistem em termos latinos adverbiais em que o primeiro literalmente significa "em segundo lugar" e o primeiro, "primeiramente", "no começo", "no primeiro momento", "de começo"; na tradução, optamos pelo modo correlato "em segundo lugar", "em primeiro lugar" (cf. ALMEIDA, Dicionário Latim-Português. Porto: Porto Editora, 2008, verbetes: "primo", "secundo").
} 
corpórea que se faz dos seus objetos encaminhando-nos para a ciência dos "abstratos absolutos" ou das coisas inteligíveis incorpóreas.

Sendo assim, a classificação das ciências filosóficas seria a seguinte:

a) as ciências que especulam as mudanças dos corpos em seus acidentes (ciências naturais);

b) as ciências que especulam as quantidades abstratas contínuas (na matéria), ou descontínuas (sem a matéria); portanto, a grandeza ou medida e a pluralidade ou números absolutos (ciências matemáticas);

c) as ciências que especulam os conceitos mentais apreendidos pelo raciocínio lógico ou silogístico (ciências lógicas);

d) as ciências que especulam as coisas existentes abstraídas da matéria (ciências intelectuais).

Nesta nova classificação das ciências filosóficas que depreendemos do texto aviceniano em questão, o que percebemos de novidade é o fato de a Lógica ser considerada uma ciência especulativa, com seu próprio objeto formal de investigação, e não uma "ciência" instrumental ou propedêutica, como se costuma apresentar; colocada acima das ciências matemáticas, a um grau das ciências das coisas absolutamente abstratas (separadas da matéria).

Nessa gradação de abstração, saltamos das ciências lógicas à delimitação do que consiste o objeto de investigação das ciências intelectuais, passando dos conceitos mentais às substâncias e existências em si mesmas.

\section{II.3. Considerações sobre a especulação referente à "substância" $e$ "existência"}

Como já afirmado tantas vezes pelo nosso autor, as substâncias enquanto tais, ou as coisas existentes em si mesmas, abstraindo-se de qualquer atribuição ou característica contingente, não poderiam ser especuladas em nenhuma das ciências até então apresentadas, porquanto elas investigam aspectos acidentais das realidades. Sendo assim, faz-se necessário a existência de uma ciência filosófica que pesquise sobre elas, as coisas absolutamente abstratas, as coisas apreendidas pelo intelecto, abstraindo de toda a percepção dos sensíveis, constituindo-se naquilo que Avicena denominou primeiramente de "ciências intelectuais", ciências da intelecção e não da percepção, ou seja, uma ciência que se adquire puramente mediante a reflexão intelectual sem a apreensão de nenhuma informação pelos sentidos anímicos. 
Sendo assim, seguimos as considerações de nosso autor referente à substância e à existência.

Avicena inicia o tema com a seguinte afirmação:

Deinde consideratio de substantia inquantum est ens vel est substantia, vel de corpore inquantum est substantia, et de mensura et numero inquantum habent esse et quomodo habent esse, et de rebus formalibus quae non sunt in matéria, vel, si sint in matéria, non tamen corpórea, et quomodo sunt illae, et quis modus est magis proprius illis, separatim per se debet haberi. Non enim potest esse subiectum alicuius scientiarum de sensibilibus nec alicuius scientiarum de eo quod habet esse in sensibilibus. Nam aestimatio est exspoliatio a sensibilibus; haec autem sunt de universitate eorum quae habent esse separata a matéria. Manifestum est enim quod esse substantia, inquantum est substantia tantum, non pendet ex matéria; alioquin non esset substantia nisi sensibilis. ${ }^{57}$

Além disso, a consideração sobre a substância, enquanto é existente ou substância, ou sobre o corpo, enquanto é substância; sobre a medida ou o número, enquanto possuem existência, ou do modo que possuem existência; sobre as coisas formais que não existem na matéria, ou, se existem na matéria, todavia não [são] corpóreas; pelo modo que elas existem e que modo lhes é mais próprio, deve ser tido por si separadamente; porquanto a existência não pode ser o objeto formal de alguma das ciências sobre os sensíveis, nem de alguma das ciências sobre o que possui existência nos sensíveis; pois, a avaliação é o despojamento dos sensíveis. Porém, estes provêm da totalidade das que possuem a existência separada da matéria. Pois, reconhece-se que a existência da substância, enquanto é apenas substância, não depende da matéria; por outro lado, não havia substância, a não ser sensível.

Avicena propõe a consideração de três pontos:

a) Sobre a substância em si mesma, como um existente ou mesmo como um corpo subsistente;

b) Sobre quantidade abstrata (medida e número) enquanto dotada de existência e o modo em que ela é dotada de existência;

c) Sobre as formas abstraídas da matéria e incorpóreas.

A respeito das "coisas existentes", podemos simplesmente dizer que esta ciência consiste na ciência das coisas reais e não imaginárias, em outras palavras, pelas coisas enquanto tais em si mesmas e não por uma construção ficcional. Esta afirmação, à

\footnotetext{
${ }^{57}$ Avicenna, op. cit., p. 10.
} 
primeira vista um tanto estranha, se refere, talvez, às narrativas fantásticas criadas pelos poetas, os mythoi, que procuravam dar uma explicação às coisas naturais através de imagens discursivas elaboradas remetendo a realidades "transcendentais" 58.

Ao contrário, esta ciência procura conhecer a coisas existentes, mas pelo fato de serem simplesmente existentes, abstraídas de todos os elementos sensíveis de que se compõe. Neste sentido é chamada de substância, isto é, "aquilo que está abaixo", "princípio", "fundamento" e, portanto, a realidade imutável, ou que se mantém permanente, sob os acidentes múltiplos e mutáveis e que lhes servem de suporte e sustentáculo; e, ainda, aquilo que subsiste, isto é, que existe por si, com autonomia e independência em relação às suas qualificações e estados.

Entretanto, o autor recorda que o que era tido por substância até agora consistia numa realidade corpórea, distinguindo somente aquilo que era mutável, acidental, do que era permanente, “substancial”. Por exemplo, a alteração do quantitativo contínuo, ou seja, da medida ou da massa, não alterava a substância da coisa; assim, uma partícula de mármore não é de uma natureza, "substância", diferente de um grande bloco. Mas o autor aponta também para um outro tipo de substância: aquele abstraído de qualquer realidade sensível e separado absolutamente da matéria.

Nos parágrafos seguintes, Avicena tratará das outras modalidades, a numérica e a figurativa. Acompanhemos o seu raciocínio. Quanto ao número e quantidade, ou seja, a respeito da substância ou subsistência numérica, no qual o autor afirma o seguinte:

Numero etiam accidit esse in sensibilibus et in non sensibilibus; unde numerus, inquantum numerus est, non pendet ex sensibilibus nec ex insensibilibus. Mensura etiam commune nomen est, quia mensura, vel intelligitur dimensio quae constituit corpus naturale, vel intelligitur quantitas continua quae dicitur de linea et superfície et corpore terminato. Tu autem iam scisti differentiam inter haec duo. Nulla autem earum est separata a matéria. Mensura vero secundum primam acceptionem, quamvis non sit separata a matéria, est tamen principium essendi corpora naturalia, nec tamen ob hoc potest esse ut constitutio eorum pendeat ex ea, quasi ipsa det eis

\footnotetext{
${ }^{58}$ Cf. MELENDO, T. Metafísica da realidade. As relações entre filosofia e vida. São Paulo: I.B.F.C., 2002, p. 43-58.69-88; Idem, Iniciação à Filosofia: Razão, Fé e Verdade. São Paulo: I.B.F.C., 2005, p. 43-65; LUCE, J. V. Curso de Filosofia Grega. Do séc. VI a. C. ao séc. III d.C.. Rio de Janeiro: Jorge Zahar Editor, 1994, p.16-22; IGLÉSIAS, M. "O que é filosofia e para que serve"; "Pré-socráticos: físicos e sofistas", in: REZENDE, A. (org.). Curso de Filosofia. Rio de Janeiro: Jorge Zahar Editor, 2004, p. 11-47.
} 
constitutionem ipsam; tunc praecederet enim in esse ipsa sensibiliza; sed non est ita. $^{59}$

Também ocorre a existência pelo número nos sensíveis e nos não sensíveis; donde o número, enquanto é número, não depende dos sensíveis, nem dos insensíveis. Também a medida é um nome genérico, pois, por medida, se entende a dimensão que constitui o corpo natural, ou se entende a quantidade contínua que se afirma sobre a linha, a superfície e o corpo delimitados. Porém, já sabes a diferença entre estes dois. Portanto, nenhuma delas é separada da matéria. Na verdade, a medida, segundo a primeira acepção, embora não exista distinta da matéria, é, contudo, princípio do existir dos corpos naturais, e, todavia, por causa disto, não é possível à existência que a compleição dos corpos dependa da medida, como ela própria lhes dê a própria compleição; sendo assim, haveria precedido na existência aos próprios sensíveis, o que não aconteceu.

O número em si mesmo é uma realidade abstrata, não dependendo nem das coisas sensíveis, nem das insensíveis; entretanto, elas possuem no número uma condição que as realiza, ou seja, que torna possível sua existência concreta. Um exemplo dado pelo autor é a medida, isto é, a quantidade contínua ou a extensão corpórea. A medida em si mesma é um conceito abstrato, conforme as palavras do autor, um "nome genérico", mas que indica, segundo Avicena, quer a dimensão que o corpo ocupa no espaço, quer sua delimitação linear ou na superfície. Sendo assim, a mensurabilidade, embora tenha sua abstração, é relacionada com a matéria corpórea; e, no que se refere à dimensionalidade, não somente é relacionada com a matéria corpórea, mas também é condição para que determinado corpo exista concretamente. Entretanto, a configuração ou a forma com que um corpo recebe uma determinação, bem como sua existência, não dependem intrinsecamente de sua mensurabilidade, visto que ela lhe é acrescida como um acidente, pois, do modo contrário, se fosse a mensurabilidade um fator determinante, deveria, segundo o autor, existir por si mesma antes das coisas sensíveis, o que não se verifica.

$\mathrm{Na}$ sequência, Avicena trata ainda das formas em si mesmas e ainda uma interessante citação a respeito das coisas especuladas pela lógica.

Avicena conclui esse tópico da seguinte maneira:

Figura etiam accidentale et comitans est materiae, postquam substantiatur corpus finitum cuius spatium est superfícies finita, termini etiam sunt sub mensura,

\footnotetext{
${ }^{59}$ Avicenna, op. cit., p. 10-11.
} 
inquantum matéria perficitur per illos, et postea comitantur. Postquam autemita est, tunc figura non habet esse nisi in matéria, nec est prima causa matéria veniendi ad effectum. Mensura vero, secundum acceptionem, secundam, consideratur secundum esse suum er secundum sua accidentalia. Sed consideratio de ea secundum esse suum, scilicet de quo modo essendi et de qua divisione essendi sit, non est etiam ut consideratio de eo quod [non] pendet ex matéria. Subiectum etiam logicae secundum se manifestum est esse praeter sensibiliza. Manifestum est igitur quod haec omnia cadunt in scientiam quae profitetur id cuius constitutio non pendet ex sensibilibus. ${ }^{60}$ Também a figura acidental e concomitante é da matéria, depois que é substanciado o corpo finito, cujo espaço é a superfície finita; também os limites estão sobre medida, enquanto a matéria é aperfeiçoada por eles e, em seguida, são unidas. Desse modo, a figura não possui a existência a não ser na matéria, e nem é a primeira causa da matéria que se efetua. Na verdade, a medida, conforme a segunda acepção, é considerada de acordo com a sua existência e conforme seus acidentes. Mas a consideração sobre ela segundo sua existência, isto é, sobre qual seja o modo de existir e sobre qual seja a divisão do existir, também não é como a consideração sobre aquilo que não depende da matéria. Também o objeto formal da Lógica, segundo se reconhece a existência além das coisas sensíveis. Portanto, se reconhece que todas essas coisas se encontram na ciência que se propõe aquilo cuja compleição não depende dos sensíveis.

A figura consiste no aspecto externo que a matéria corpórea assume ao ser substanciada, ou seja, ao adquirir um substrato que a define e a torne real dentro de um espaço determinado e, portanto, ao adquirir uma medida. Sendo assim, a figura é dependente da matéria, constituindo num resultado acidental após a sua determinação substancial e, portanto, como afirma o autor, não pode ser primeira causa daquilo que se efetua.

Do mesmo modo, a medida, no sentido de quantidade contínua ou de extensão linear, é considerada um acidente da matéria corpórea que lhe aperfeiçoa, relacionada com a matéria e não tendo existência própria, ou subsistência, ela deve ser investigada de acordo com sua relação com a coisa existente e seus acidentes e não como se investiga algo separado da matéria.

Avicena conclui o parágrafo em questão afirmando que o objeto formal da Lógica consiste naquilo que "se reconhece a existência além das coisas sensíveis", ou seja,

\footnotetext{
${ }^{60}$ Idem, 11-12.
} 
naquelas coisas existentes que não se classificam entre as realidades sensíveis. Mais uma vez, o autor coloca a Lógica acima das demais ciências filosóficas, identificando-a como uma ciência das coisas não-sensíveis e, portanto, a um passo das intenções desta nova ciência que ora se propõe, cujo objeto se dirige exatamente para os não-sensíveis ou inteligíveis.

Em suma, para delimitar o objeto de investigação desta ciência que se propõe, o autor procura distinguir aquilo que depende da matéria daquilo que está separado da matéria, levando em conta a gradação que existe entre esses - podemos dizer assim extremos. Sendo assim, ele distingue o substancial, ou seja, a coisa em si, daquilo que se lhe acrescenta, necessariamente ou não, mas, em todo caso, não consiste num fator determinante, como, por exemplo, a medida, enquanto extensão linear, é algo acidental, não substancial, mas necessário na concretude da coisa existente em relação ao espaço que ocupa.

As demais ciências filosóficas (exceto a Lógica) investigam as coisas relacionadas de algum modo com a matéria ou com a realidade corpórea, quer direta, quer indiretamente. Não tem como objeto a existência em si mesma ou a substancialidade das coisas existentes, mas tão somente os aspectos acidentais das coisas existentes. Todavia, as ciências matemáticas possuem um grau de abstração nas coisas que investiga, embora não estejam estas de todo separadas do corpóreo, como é o caso da mensurabilidade e dos números abstratos, porquanto é chamada esta ciência de ciência média.

A Lógica, como já foi afirmado, trata de coisas não-sensíveis, imateriais ou incorpóreas, podemos mesmo dizer racionais. Sendo assim, indica-se a necessidade de uma ciência que trate da existência e substância, das coisas separadas da matéria e que podem ser conhecidas não pela percepção dos sentidos, mas unicamente pela intelecção ou pelo conhecimento especulativo ou contemplativo. É nessa direção que se vai delineando o objeto de pesquisa das "ciências intelectuais".

\section{II.4. A existência como unidade das "coisas" especuladas nas várias ciências}

Na sequência, tendo em vista o processo de delimitação do campo de investigação das ciências intelectuais, o autor faz a triagem daquilo que é especulado nas outras ciências filosóficas, apontando aquilo que não pode ser comum a todas elas, ou seja, o que lhes é uno, excetuando sempre a existência como elemento básico comum, e aquelas coisas que não são tratadas por nenhuma delas, mas, pela sua singularidade e abstração, devem ser especuladas em outra ciência que não estas que até então se conhecem. 
Sigamos, então, o raciocínio de Avicena:

Sed non potest poni eis subiectum communne, ut illorum omnium sint dispositiones et accidentalia communia, nisi esse. Quaedam enim eorum sunt substantiae, et quaedam quantitates, et quaedam alia praedicamenta; quae non possunt habere communem intentionem essendi. Similiter etiam sunt res quae debent definire et verificari in anima, quae sunt communes in scientiis; nulla tamen earum tractat de eis, sicut est unum inqunatum est unum, et multum inquantum est multum, conveniens et inconveniens, contrarium et cetera. De his enim mentionem tantum faciunt et inducunt definiones eorum, nec tamen loquntur de modo essendi eorum, quia haec nec sunt accidentia própria alicui subiectorum harum scientiarum particularium, nec sunt de rebus quae habent esse nisi proprietates esse essentialiter, nec sunt etiam de proprietatibus quae sunt communes omni rei sic ut unumquodque eorum sit commune omni rei, nec possunt esse própria alicuius praedicamenti, nec possunt esse accidentalia alicui nisi ei quod est esse, inquantum est esse. ${ }^{61}$

Mas não pode ser proposto a elas [às ciências] um objeto formal comum, de modo que sejam comuns a todos eles [os objetos] as disposições e os acidentes, a não ser a existência. Pois, alguns deles são substâncias; outros, quantidades; outros ainda, predicamentos, os quais não podem ter uma intenção comum que os determinem, a não ser a intenção de existir. Também, de modo semelhante, são as coisas que devem definir e serem verificadas na alma que são comuns nas ciências; todavia, nenhuma das ciências trata sobre elas, assim como é o uno enquanto uno, múltiplo enquanto múltiplo, conveniente e inconveniente, contrário e assim por diante. Pois, destes fazem somente menção e induzem às suas definições, ainda que não falem do modo de existir deles, porque eles não são acidentes próprios de algum dos objetos formais destas ciências particulares, nem são das coisas que possuem existência, a não ser as propriedades essenciais da existência, nem existem também a partir das propriedades que são comuns a toda coisa, assim como cada um deles é comum à toda coisa, nem é possível às existências próprias de algum predicamento, nem à existência de alguns acidentes, a não ser aquele que possui existência, enquanto é existência.

Dentre os aspectos das coisas especuladas pelas ciências filosóficas mencionadas (que são ciências particulares por não tratarem daquilo que seja comum à todas as coisas) não há nada de comum, isto é, não há nada que seja uno a todos os objetos formais das referidas ciências que possa ser especulado pela Primeira Filosofia, algo que seja o

\footnotetext{
61 Idem, 12.
} 
fundamento comum de tudo aquilo que é especulado pelas filosofias naturais, matemáticas e lógicas que não seja a existência ou a intenção de existir, porquanto, como Avicena diz, cada ciência especula um aspecto da coisa: enquanto são substâncias (física), ou quantidades (matemática) ou, ainda, predicamentos (lógica). Ora, nenhum deles são determinados por intenções comuns, pois, como é evidente, são aspectos diversos para serem especulados por distintas ciências. Entretanto, a existência, ou "a intenção do existir", como sublinha o autor, é algo que possuem em comum, embora isto não possa ser objeto de investigação de nenhuma das ciências citadas, como já ficou claro no capítulo anterior.

Avicena recorda, ainda, que aquilo que é comum a todas as ciências particulares, isto é, a todas as ciências filosóficas já mencionadas, consiste naquilo que se procura definir e verificar "na alma", isto é, mediante a reflexão operada pelo intelecto, que não está necessariamente ligado à matéria e, portanto, constituem conceitos imateriais e incorpóreos como, por exemplo, segundo o que o autor mesmo indica, "o uno enquanto uno, múltiplo enquanto múltiplo, conveniente e inconveniente, contrário e assim por diante". Estes são conceitos abstratos que não cabem, por isso, na investigação de nenhuma outra ciência, porquanto as demais ciências não tratam deles por não serem acidentes das coisas subsistentes que são especuladas por elas, excetuando as propriedades essenciais da existência, ou seja, aquilo que é inerente à coisa existente. De tais conceitos se faz somente menção e induzem às suas definições, ainda que não se refiram ao modo de existir deles, porque eles não são acidentes próprios de algum dos objetos formais destas ciências particulares, nem são das coisas que possuem existência, a não ser as propriedades essenciais da existência, nem existem também a partir das propriedades que são comuns a toda coisa, assim como cada um deles é comum a toda coisa, nem é possível às existências próprias de algum predicamento, nem à existência de alguns acidentes, a não ser aquele que possui existência, enquanto é existência.

Em suma, o simples ato de existir, ou o fato de estar dotado de existência, é o único elemento comum a todas as coisas que são investigadas pelas demais ciências (particulares) filosóficas, o seu uno, e que não consiste num acidente secundário, mas é algo inerente à todas as coisas. Sendo assim, a "intenção do existir" não pode ser relativa a nenhuma das ciências particulares, que investigam tão somente os aspectos abstraídos daquilo que se estuda, pois o que elas estudam ou está relacionado à matéria, ou, ao menos, lhe é um predicado abstraído pelo raciocínio, todavia não é um princípio imaterial 
como é o "ato de existir", que não se percebe como um corpo, mas através das realidades deles é percebido.

\section{II.5. O "existente" como objeto formal de investigação}

Na sequência, Avicena procura argumentar que o existente é o objeto investigado por esta ciência filosófica em questão, enquanto alguns existentes são princípios para as outras ciências, porém não especula sobre os princípios dos existentes. Acompanhemos o seu raciocínio.

Igitur ostensum est tibi ex his omnibus quod ens, inquantum est ens, est commune omnibus his et quod ipsum debet poni subiectum huius magisterii, et quia non eget inquiri an sit et quid sit, quasi alia scientia praeter hanc debeat assignare dispositionem eius, ob hoc quod inconveniens est ut stabiliat suum subiectum an sit et certificet quid sit scientia cuius ipsum est subiectum, sed potius debet concedere tantum quia est et quid est. Ideo primum subiectum huius scientiae est ens, inquantum est ens; et ea quae inquirit sunt consequentia ens, inquantum est ens, sine condicione. Quórum quaedam esse non eget dividi in alia priusquam in ista, sicut substantia eget dividi in alia antequam perveniat ad dividendum in hominem et non hominem. Et ex his quaedam sunt ei quase accidentalia própria, sicut unum et multum, potentia et effectus, universale et particulare, possibile et necesse. Per hoc autem quod ens recipit haec accidentia et coaptaturillis, non est necesse illud proprie fieri vel naturale vel disciplinale vel morale vel aliquid aliorum. ${ }^{62}$

Portanto, de tudo isso, foi-te mostrado que o existente, enquanto é existente, é comum a todos estes; e que o próprio objeto formal deste magistério convém ser fixado, também porque não se necessita pesquisar se existe e o que é, como se outra ciência, salvo esta, deva conceder sua disposição perante isto que é inconveniente a fim de estabelecer o seu objeto formal, se existe, e estar certo que exista a ciência cujo próprio objeto formal existe; porém, é mais conveniente admitir tão somente o porquê existe e o que é. Por esta razão, o primeiro objeto formal desta ciência é o existente, enquanto é existente; e aquilo que se pesquisa é, por consequência, o existente, enquanto é existente, sem condição. Alguns dos quais existem nele como espécie, como substância, quantidade, qualidade, visto que a existência não necessita ser dividida em outras antes que nesta, assim como a substância não necessita ser dividida em outra antes que chegue a ser dividida no homem e não o homem. A partir disso, alguns estão nele como coisas acidentais próprias, como uno e múltiplo,

${ }^{62}$ Idem, 12-13. 
potência e efeito, universal e particular, possível e necessário. Portanto, por meio disto que o existente recebe estes acidentes e se ajuste a eles, não sendo necessário que ele propriamente se realize [nas ciências] naturais, disciplinares, morais ou alguma outra.

Neste parágrafo, Avicena conclui que, a partir de tudo o que já foi dito, o que há de comum em todas as ciências filosóficas é o fato de elas investigarem um existente e, portanto, o existente (ens) é um objeto comum de todas as ciências. Cada ciência toma um aspecto de determinados modos de existir como seu objeto formal, de modo que certos existentes são princípios de determinadas ciências. Esta ciência em questão, entretanto, especula os existentes enquanto é um existente, segundo o que ele é (substância, essência, natureza) e qual a razão de existir (finalidade), sem fazer abstração de aspectos ou atributos que lhe são relativos e modificáveis (quantidade, movimento). Porém tratando de acidentes que lhe são inerentes como ser uno ou múltiplo, estar em estado potencial ou em efeito, se é um universal (conceito genérico) ou particular (específico), se é um existente possível (contingente) ou necessário.

E em continuidade a isso, diz:

Potest autem quis dicere quod, postquam ens ponitur subiectum huius scientiae, tunc non potest esse ut ipsa stabiliat esse principia essendi. Inquisitivo enim omnis scientiaenon est de principiis, sed de consequentibus principiorum. Ad quod respondemus quod speculatio de principiis non est nisi inquisitivo de consequentibus huius subiecti, quia ens hoc vel illud, inquantum est principium, non contituitur ab eo nec prohibetur, sed, comparatione naturae entis absolute, est quiddam accidentale ei et est de consequentibus quae sunt ei própria; principium enim non est communius quam ens, quasi consequatur cetera consecutione prima. Nec etiam necesse est ut sit naturale vel disiplinae vel aliquid aliud, ad hoc ut accidat ei esse principium. Deinde principium non est principium omnium entium. Si enim omnium entium esset principium, tunc esset principium sui ipsius; ens autem in se absolute non habet principium, sed habet principium unumquodque esse quod scitur. Principium igitur est principium aliquibus entibus. Quapropter haec scientia non erit inquirens principia entis absolute, sed principia alicuius entium, sicut principia ceterarum scientiarum particulatium. Quamvis enim ceterae scientiae non probent esse principiorum suorum communium (habent enim principia in quibus 
communicant omnes de quibus unaquaeque earum tractat), ipsae tamen probant esse principiorum earum rerum quae sunt in eis. ${ }^{63}$

Porém, alguém pode dizer que, depois que o existente é considerado objeto formal desta ciência, então não pode a existência estabelecer-se como os princípios do existir. Pois, a investigação de toda a ciência não é sobre os princípios, mas sobre as consequências dos princípios. Ao qual respondemos que a especulação sobre os princípios não existe a não ser a pesquisa sobre as consequências deste objeto formal, porque o existente é isto ou aquilo, enquanto é princípio, e não seja constituído a partir dele, nem separado, mas pela absoluta comparação da natureza do existente, é algo acidental a ele e existe a partir das consequências que lhe são próprias; pois, o princípio não é mais comum que o existente, como segue outras coisas pela primeira consequência. Também, não é necessário que seja natural, disciplinar [matemático], ou algum outro, e ainda como lhes ocorre existir o princípio. Demais, o princípio não é princípio de todos os existentes. Pois, se fosse o princípio de todos os existentes, então seria o princípio de si mesmo; porém, o existente em si não possui absolutamente princípio, mas cada existência tem o princípio que se sabe. Portanto, o princípio é princípio a alguns existentes. Por isso, é que esta ciência não será a que investiga os princípios do existente em absoluto, mas os princípios de alguns existentes, como os princípios de outras ciências particulares. Pois, embora outras ciências não demonstrem a existência dos seus princípios comuns (pois possuem os princípios nos quais tem em comum todos eles sobre os quais cada uma delas trata), todavia elas próprias demonstram a existência dos princípios de suas coisas que existem nelas.

Avicena levanta uma possível questão: sendo o existente em si o objeto de especulação desta ciência, fica impossibilitado de se estabelecer a existência como princípio do existir, visto que uma ciência especula somente a respeito das consequências de um princípio e não o seu princípio que é suposto.

Avicena responde esta questão afirmando que o princípio não é mais comum, isto é, genérico, que o existente, pois cada existente é consequência de um determinado princípio, e que os existentes são, por sua vez, princípios de outras tantas coisas que são investigadas pelas demais ciências filosóficas. Por outro lado, cada ciência deve ter como pressuposto os princípios do objeto por ela investigado, sendo assim, não há ciência que tenha como objeto de pesquisa o "princípio", de modo genérico, pois, como já dito, não

\footnotetext{
${ }^{63}$ Idem, 13-14.
} 
há o universal "princípio", porquanto um existente é consequência de um princípio particular e pode ser princípio de outros. Sendo assim, o existente enquanto tal é o que há de mais genérico e fundamental e deve ser tratado pela Primeira Filosofia.

Do que se afirmou anteriormente: que a existência, ou a "intenção de existir", é o uno de tudo aquilo que as demais ciências especulam, portanto, todas as ciências particulares possuem um existente como objeto material de seu estudo, a partir do qual elegem um aspecto seu a fim de ser investigado; segue-se, então, que a Primeira Filosofia tem por intenção as coisas existentes em si mesmas, em sua concretude, sem abstrair algum aspecto em seu estudo, porquanto alguns desses existentes se convertem em princípios pressupostos para o estudo das demais ciências. E como cada existente possui o seu próprio princípio, não havendo nenhum princípio genérico que possa ser o uno, não há possibilidade de nenhuma ciência especular qualquer princípio, na condição de princípio, excluindo-se, desse modo, a possibilidade de investigar a existência como princípio do existir.

\section{II.6. A divisão desta nova ciência filosófica em partes}

Diante de tudo que foi dito, Avicena demonstra que as várias possibilidades de existência e suas consequentes relações induzem à necessidade de a Primeira Filosofia ter suas partes ou divisões de modo a abarcar todas as condições dos existentes.

Atentemos, portanto, ao que ele diz:

Sequitur ergo necessário ut haec scientia dividatur in partes, quarum quaedam inquirunt causas ultimas, inquantum sunt causae omnis esse causati inquantum est esse; et aliae inquirunt causam primam ex qua fluit omne esse causatum inquantum est esse causatum, non inquantum est esse mobile vel quantitativum; et quaedam aliae inquirunt dispositiones quae accidunt esse; et quaedam inquirunt principia scientiarum particularium; principia enim uniuscuiusque scientiarum minus communium quaestiones sunt in scientia communiori, sicut principia medicinae in naturali, et principia mensurationis in geometria. Contingit igitur ut in hac scientia monstrentur principia singularium scientiarium quae inquirunt dispositiones uniuscuiusque esse. Igitur haec scientia inquirit dispositiones esse et ea quae sunt ei quasi partes et species, quousque pervenitur ad apropriationem ex qua provenit subiectum naturalis. Igitur permittamus illam appropriationem ei; et appropriationem ex qua provenit subiectum disciplinalis, permittamus ei, et similiter 
ceteris. Id autem quod praecedit illud subiectum et est ei sicut principium, nos inquiremus et stabiliemus eius dispositiones. ${ }^{64}$

Portanto, segue-se forçosamente que esta ciência seja dividida em partes, das quais algumas investigam as últimas causas, enquanto são causas de todas as existências causadas enquanto é existência; outras investigam a primeira causa da qual emana toda a existência causada enquanto é existência causada, não enquanto é existência móvel ou quantitativa; outras investigam as disposições que ocorrem existência; outras, ainda, investigam os princípios das ciências particulares; pois, os princípios de cada uma das ciências menos comuns são questões em ciências mais comuns, como os princípios da medicina nas [ciências] naturais, ou os princípios das medições na Geometria. Portanto, cabe a esta ciência demonstrar os princípios das ciências particulares que investigam as disposições de cada existência. Portanto, esta ciência investiga as disposições da existência e aquilo que lhe são como partes e espécies, até atingir a apropriação da qual provém o objeto formal das [ciências] naturais. Portanto, lhe concedamos a apropriação da qual provém o objeto formal das ciências disciplinares [matemáticas], concedamos a ela e do mesmo modo às outras. Porém, isto que precede àquele objeto formal e lhe é como o princípio, nós investigamos e estabelecemos suas disposições.

Avicena, portanto, percebe quatro divisões desta ciência (como ocorre também na Matemática):

a) A primeira consiste na investigação das últimas causas, na medida que estas são, também elas, coisas existentes, a saber: a causa eficiente, ou seja, o existente que é causa ou princípio do existir de outra coisa existente;

b) A segunda consiste na investigação do "primeiro existente" enquanto é a primeira causa ou a causa primordial de todos os existentes "causados" ou que receberam existência;

c) A terceira consiste nas disposições ou tendências da existência, ou, melhor dizendo, dos existentes ou de tudo aquilo que possui existência;

d) A quarta divisão trata dos princípios das ciências particulares, pois, segundo ele, todo o princípio de uma ciência específica é uma questão a ser investigada numa ciência mais genérica. Avicena exemplifica com os princípios da medicina que são tradados pelas ciências naturais, ou os princípios da medição, investigados pela Geometria.

\footnotetext{
${ }^{64}$ Idem, 14-15.
} 
A partir disso, Avicena tira três conclusões:

a) É função da Primeira Filosofia investigar sobre os princípios das ciências particulares, ou específicas, às quais cabem estudar as disposições ou tendências destes mesmos princípios;

b) A Primeira Filosofia investiga tão somente as disposições da existência enquanto tal (e não de algum existente em particular como princípio de outra ciência), seus gêneros e espécies, até atingir o que é próprio do estudo das demais ciências;

c) Sendo assim, atribuiem-se à Primeira Filosofia os princípios das demais ciências como seu objeto de estudo.

Avicena, porém, faz a seguinte observação: "Porém, isto que precede àquele objeto formal e lhe é como o princípio, nós investigamos e estabelecemos suas disposições", ou seja, o objeto de estudo da Primeira Filosofia são os existentes enquanto tais, incluso o existente primordial ou causa absoluta de tudo. O que lhes precede como princípio, não se pode ser especulado por esta ciência, mas tão somente, suas disposições e efeito. Isso ficará mais claro a seguir.

Igitur quaestiones huius scientiae quaedam sunt causae esse, inquantum est esse causatum, et quaedam sunt accidentalia esse, et quaedam sunt principia scientiarum singularum. Et scientia horum quaeritur in hoc magistério. Et haec est philosophia prima, quia ipsa est scientia de prima causa esse, et haec est prima causa, sed prima causa universitatis est esse et unitas; et est etiam sapientia quae est nobilior scientia qua apprehenditur nobilius scitum: nobilior vero scientia, quia est certitudo veritatis, et nobilius scitum, quia est Deus, et causae quae sunt post eum; et etiam cognitio causarum ultimarum omnis esse, et cognitio Dei, et propterea definitur scientia divina sic quod est scientia de rebus separatis a matéria definitione et definitionibus, quia ens, inquantum est ens, et principia eius et accidentalia eius, inquantum sunt, sicut iam patuit, nullum eorum est nisi praecedens materiam nec pendet esse eius ex esse illius. Cum autem inquiritur in hac scientia de eo quod non praecedit materiam, non inquiritur in ea nisi secundum hoc quod eius esse non eget matéria. ${ }^{65}$

Portanto, certas questões desta ciência são causas da existência, enquanto é existência causada; outras são coisas acidentais da existência; outras, ainda, são princípios das ciências particulares. E a ciência destes princípios busca-se neste magistério. Esta é a Primeira Filosofia, porque ela própria é a ciência que provém da

${ }^{65}$ Idem, 15-16. 
primeira causa da existência, e esta é a primeira causa, mas a primeira causa da totalidade é a existência e a unidade; é também a Sapiência que é a mais nobre ciência pela qual se apreende o mais nobre axioma; na verdade, é a mais nobre ciência, porque é a certeza da verdade e o mais nobre axioma, que é Deus e as causas que existem depois dele; é também o conhecimento das últimas causas de toda a existência e o conhecimento de Deus, por isso é definida como Ciência Divina; porquanto, é a ciência das coisas separadas da matéria por definição e definições, porque o existente, enquanto é existente, e seus princípios e acidentes, enquanto existem, como é evidente, nenhum deles existe, a não ser os que precedem a matéria, nem depende sua existência a partir da existência daquele. Porém, enquanto se investiga nesta ciência sobre aquilo que não precede a matéria, não se investiga nela a não ser conforme isto que sua existência não necessita da matéria.

Avicena retoma em síntese nestas três afirmações:

a) Algumas questões estudadas pela Primeira Filosofia referem-se às causas das existências causadas, ou seja, os existentes enquanto princípios do existir de outras;

b) Outras são acidentes dos existentes, ou seja, são existentes secundários, pois subsistem em outro;

c) O terceiro são os existentes enquanto são princípios de outras ciências.

Avicena vai delimitando a definição desta ciência filosófica a partir das três qualificações a ela dadas anteriormente: "primeira filosofia", "sapiência" e "ciência divina", nomenclaturas que serão analisadas com maior detalhe no terceiro capítulo da obra em questão, e também definindo como uma "ciência dos existentes em si" sem nenhuma denominação precisa. Explicitemos o que ele diz:

a) Avicena denomina esta ciência filosófica como Primeira Filosofia pelo fato de ela tratar da primeira causa dos existentes, que consiste na própria existência enquanto tal juntamente com a unidade;

b) Chama-a também de Sapiência por considerá-la a mais nobre das ciências em razão de, por ela, se apreender o "mais nobre axioma", identificado com Deus e as causas que lhe seguem, e por adquirir a certeza da verdade;

c) Sendo assim, é também chamada de Ciência Divina, por ser o conhecimento de Deus e das "últimas causas", ou causas supremas; 
d) Por fim, é a ciência dos existentes em si ("ontologia"), porquanto estuda as coisas separadas da matéria, seus princípios e acidentes, enquanto são existentes; em outras palavras, investiga as coisas existentes e a existência enquanto tal.

Na sequência, Avicena discorre sobre os quatro tipos de existentes e o modo como são investigados pela ciência em questão. Atentemos ao que ele diz:

Eorum autem quae inquiruntur in ea quattuor sunt; quorum quaedam sunt separata a matéria et ab appendiciis materiae omnino, et quaedam sunt commixta materiae, sed ad modum quo commiscetur causa constituens et praecedens (materia enim non est constituens illa) et quaedam sunt quae invniuntur in matéria et non in matéria, sicut causalitas et unitas; quapropter ea quae habent communiter, inquantum sunt tália, sunt quod ad certificationem sui non est opus esse matéria; omnia autem communicant in hoc quod esse eorum non est materiale, scilicet ut esse eorum sit ex matéria. Et quaedam sunt res materiales, sicut motus et quies, sed de eis non inquiritur in hac scientia secundum quod sunt in matéria, sed secundum esse quod habent. Cum igitur haec pars divisionis accepta fuerit cum aliis partibus divisionis, tunc omnes communicant in hoc quod inquisitivo de his non est nisi secundum modum quo esse eorum non est existens per materiam. Et sicut in scientiis disciplinalibus ponunt id quod est terminatum per materiam, et inquisitivo et consideratio de eo est illius modi secundum quem id quod quaeritur de eo peendet ex matéria, et haec inquisitivo non est disciplinalis: sic est dispositivo haec. Monstratum est ergo quae sit intentio in hac scientia. ${ }^{66}$

Portanto, existem quatro delas que são investigadas nesta ciência, algumas das quais são totalmente separadas da matéria e dos que dependem da matéria; existem outras misturadas à matéria, mas ao modo pelo qual se mistura a causa constituinte e a precedente (pois, a matéria não é aquela constituinte) e existem outras, ainda, que tanto se encontram na matéria, como não [se encontram] na matéria, como a causalidade e unidade; por isso, aquelas coisas que elas possuem em comum, enquanto são semelhantes, existem a fim de certificar-se de que não é necessário existir como matéria; porquanto, todas elas possuem em comum o fato de a existências delas não é material, ou seja, que a existência delas necessite existir a partir da matéria. Algumas, também, são coisas materiais, como movimento e repouso, mas a investigação sobre elas nesta ciência não se faz segundo sua existência na matéria, mas segundo a existência que possuem. Portanto, esta parte da divisão foi aceita tanto como as outras, então todos tem em comum isto que a

${ }^{66}$ Idem, 16-17. 
investigação sobre elas não é senão segundo o modo pelo qual a sua existência não subsiste através da matéria. Sendo assim, nas ciências disciplinares [matemáticas], estabelece-se o que é determinado pela matéria, e tanto a investigação, como a consideração sobre aquilo é do modo segundo o qual aquilo que se busca sobre ele depende da matéria, e esta investigação não é disciplinar [matemática]; assim é esta disposição. Portanto, reconhece-se qual é a intenção nesta ciência.

Os quatro tipos de existentes que Avicena elenca são os seguintes:

a) Os existentes totalmente separados da matéria que são os inteligíveis, espirituais ou divinos;

b) Aqueles que estão unidos à matéria, ainda que delas se distingam, ou seja, as formas substancias ou determinantes;

c) As que se encontram na matéria, ou subsistem mediante ela, em outras palavras, os existentes naturais acidentais ou secundários (dependentes);

d) As que não estão unidas à matéria e que constituem predicamentos ou conceitos racionais ou lógicos (os "entes de razão"), que Avicena exemplifica com a causalidade e a unidade.

Em seguida, após elencar os tipos de existentes, Avicena procura fazer os seguintes esclarecimentos que, em síntese, podemos dizer o seguinte:

a) Os subsistentes em si possuem caracteres comuns que os tornam semelhantes e cuja função, segundo ele, é demonstrar que a necessidade de sua existência independe da matéria;

b) As formas substanciais possuem em comum a sua imaterialidade, embora sua existência esteja ligada à matéria enquanto existem por elas como seu determinante;

c) os existentes naturais possuem sua existência a partir da matéria, sendo dela totalmente dependente como efeito; a Primeira Filosofia as estuda enquanto são existentes;

d) no concernente às existências lógicas, Avicena afirma que foi aceita como parte da divisão de modo idêntico às demais e, portanto, seu estudo se faz concebendoas como existências separadas de matéria;

e) por fim, no referente àquilo que se estuda nas Matemáticas é estabelecido a partir da matéria, mas interessa à Primeira Filosofia na condição de existente, o que não ocorre na Matemática. 
A partir do que foi dito, Avicena conclui que se nos torna evidente qual é a intenção desta ciência, ou seja, estudar os existentes e suas disposições.

Do que podemos concluir destes parágrafos estudados é que, para Avicena, esta ciência que ele denomina ora como Primeira Filosofia, ora como Ciência Divina ou, ainda, como Sapiência - e poderíamos acrescentar Ciência Intelectual - consiste, sobretudo, numa ciência das "coisas existentes" (entia) na sua condição simplesmente de "existente"; para usar uma nomenclatura moderna, ela consiste numa Ontologia ${ }^{67}$, ou a "Ciência do Existente".

Avicena propõe uma divisão desta ciência, à semelhança do que ocorre com as demais, de acordo com uma certa classificação que propõe na divisão do "existente". Existem aqueles, segundo ele afirma, que são causas de outros existentes; então há uma divisão que estuda os existentes causantes (Etiologia).

Existem outros que são princípios a fim de serem especulados em determinado aspecto pelas outras ciências; então, existe uma divisão que estuda os princípios, na condição de serem existentes, como é óbvio (Arquilogia ${ }^{68}$ ).

Há, também, uma divisão que estuda os existentes que são as últimas causas ou o princípio absoluto e, consequentemente, estuda o divino, mas somente nas suas disposições e efeitos, visto que não podem ser especulados em si mesmos por nenhuma ciência (Teologia).

Por fim, Avicena elenca quatro tipos de existentes aos quais interessam a esta ciência estudar: a) os que subsistem por si mesmos separados da matéria; b) os que se distinguem da matéria, mas subsistem nela; c) os que dependem ou tem sua origem na matéria; d) os existentes lógicos, também eles separados da matéria.

Como a ciência lógica possui afinidade com a Primeira Filosofia em razão de seu objeto ser imaterial, segundo Avicena, na sequência, ele fará uma comparação com dois ramos - podemos dizer assim - da Lógica: a Tópica e a Sofística.

\section{II.7. Comparação da Primeira Filosofia com a Tópica e a Sofística}

\footnotetext{
${ }^{67}$ O termo "ontologia" (literalmente "ciência do existente") foi introduzido pelo filósofo alemão Rudolph Goclenius, professor da Universidade de Marburg, em seu Lexicon Philosophicun (1613) e que a partir de então foi sendo usado como sinônimo de metafísica como a ciência do ser em seu sentido mais geral (cf. JAPIASSÚ, op. cit., verbete: “ontologia”).

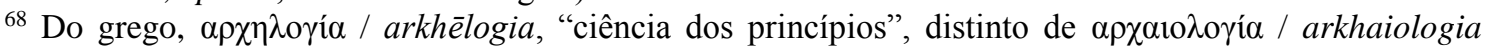
(arqueologia), "ciência das cosias antigas".
} 
No último parágrafo do capítulo em questão, Avicena, ao comparar a Primeira Filosofia com a Tópica e a Sofística, aponta aquilo que há de comum entre elas e aquilo que as diferencia. Atentemos ao que ele diz:

Haec autem scientia communicat cum Topica et Sophistica simul in aliquibus et differt ab eis simul in aliquibus et differt ab unaquaque earum in aliquibus. Communicat enim cum eis in hoc quod de eo quod hic inquiritur nullus auctorum singularum scientiarum tractat, nisi topicus et sophisticus. Differt vero ab eis simul in hoc quod philosophus primus, inquantum est philosophus primus, non loquitur de quaestionibus singularum scientiarum; isti vero loquuntur. Differt etiam a tópico per se in fortitudine eo quod verbum topici acquirit opinionem, non certitudinem, sicut nosti ex magistério logicae. Differt etiam a sophistico in voluntate, eo quod hic quaerit ipsam veritatem, ille vero quaerit putari sapiens in dictione veritatis, quamvis non sit sapiens. ${ }^{69}$

Esta ciência tem algumas coisas em comum com a Tópica e a Sofística, ao mesmo tempo que difere delas em outras e difere, ainda, de cada uma delas em outras. Pois, tem em comum com elas aquilo que se investiga nesta ciência e não é tratado por nenhum dos autores das ciências particulares, a não ser os tópicos e os sofistas. Na verdade, difere deles ao mesmo tempo naquilo que o primeiro filósofo, enquanto é primeiro filósofo, não fala sobre questões das ciências particulares; de fato, esses discorrem. Também difere do tópico por si em intrepidez por aquilo que a palavra "tópico" adquire opinião, não certeza, como conhecemos a partir do ensino da Lógica. Também difere do sofista na vontade, por aquilo que aqui procura a própria verdade, de fato, ele procura ser tido por sábio ao dizer a verdade, embora não seja sábio.

Como já visto anteriormente, inclusive em quadros ilustrativos, Avicena tem aproximado as ciências lógicas das intelectuais em função da imaterialidade de seus respectivos objetos formais. Neste parágrafo ele procura fazer a distinção entre elas, enfatizando aquilo que as diferencia. Primeiramente, ele aponta o que há de comum; em seguida, ele assinala o que as difere, entre os dois grupos; depois o que difere entre a Primeira Filosofia e cada uma delas em particular. Vejamos:

a) O que há de comum entre elas é o objeto especulado, mais precisamente a qualidade desses objetos que são de natureza imaterial e incorpórea, isto é, existentes que subsistem separados da matéria;

${ }^{69}$ Idem, 17-18. 
b) O que as difere entre si é o fato de o "primeiro filósofo" (diríamos, o "metafísico" ou o "ontologista") não tratar de coisas específicas, próprias das ciências particulares; ao contrário, os tópicos e os sofistas discorrem sobre elas;

c) O que a diferencia da Tópica é o fato de esta fazer aquisição de uma opinião e não de uma certeza; o contrário se dá com a Primeira Filosofia;

d) O filósofo se distingue do sofista pela vontade em buscar a verdade; ao contrário, o sofista busca ser tido por sábio, ainda que não seja, somente por dizer a respeito da verdade.

Em síntese, o filósofo se distingue dos lógicos, acima descritos, ao procurar a compreensão da realidade das coisas existentes em si mesmas e não somente obter uma mera opinião e discursar sobre ela.

\section{II.8. Recapitulação geral}

A intenção de Avicena no segundo capítulo da obra em questão consiste em delimitar o objeto de estudo da Primeira Filosofia ou Ciência Divina partindo da descrição dos objetos formais das outras ciências filosóficas (físicas, matemáticas e lógicas). Ao delimitar o aspecto em que cada ciência filosófica especula, procura colocar em evidência o nicho por elas deixado e a necessidade de se estabelecer uma ciência que aborde tais aspectos que não cabem às demais.

$\mathrm{O}$ autor induz o leitor à percepção deste nicho quando, por exemplo, logo no início, indica que o objeto formal das ciências naturais é o movimento ou o repouso dos corpos, deixando de lado a sua condição de existente, substância ou sua composição de matéria e forma.

O mesmo ocorre nas ciências matemáticas. Avicena deixa claro que o que a elas interessa são as disposições e os acidentes referentes à quantidade e extensão da matéria e não se a medida e o número são percebidos sem a matéria ou na matéria.

No que se refere às ciências lógicas, Avicena distingue que o seu conhecimento se faz de modo discursivo no intelecto, partindo do juízo de uma proposição à uma conclusão, independente da percepção da existência, e acrescenta que a existência não depende da matéria corpórea, mas que não há uma dentre as ciências conhecidas que especule esse aspecto, deixando também claro o nicho.

Portanto, não há uma ciência filosófica entre as até então apresentadas (naturais, matemáticas e lógicas) que tem como objeto de estudo as coisas existentes, ou substâncias, em si mesmas, enquanto são existentes, e suas disposições ou operações, 
abstraindo-se de qualquer aspecto qualificativo ou atributivo e distinto de sua corporeidade e materialidade. Em outras palavras, não há uma ciência dos subsistentes abstraídos dos aspectos perceptíveis através dos sentidos psíquicos, nem conhecidos pelos juízos das proposições racionais, mas em sua realidade intrínseca por aquilo que simplesmente é em sua inteligibilidade.

Sendo assim, faz-se necessário o estabelecimento de uma ciência dos inteligíveis, uma ciência intelectual, pela qual se investiga as coisas existentes em si mesmas, abrindo, desse modo, um espaço para se estudar e se verificar os princípios e as causas das demais ciências filosóficas, bem como as disposições e operações da causa e do princípio absolutos, cuja demonstrabilidade de sua existência não é possível a não ser mediante seus efeitos, o que Avicena identifica com o divino.

Esta ciência, que Avicena qualifica de Primeira Filosofia ou Ciência Divina, ou ainda Sapiência, é, como as demais ciências filosóficas, dividida em partes, constituindo um conjunto de ciências, as ciências intelectuais. Como as matemáticas, Avicena divide as intelectuais em quatro ciências, como descritas na tabela a seguir, sem, contudo, lhes dar uma denominação. Cada uma delas procura especular sobre as coisas existentes de modos diversos:

a) enquanto subsistentes, ou as substâncias em si mesmas;

b) as causas enquanto substâncias primárias que originam outras;

c) os princípios enquanto suportes daquilo que as outras ciências estudam;

d) o princípio e a causa absolutos ou primordiais identificados com o divino.

A fim de ilustrar o que estamos dizendo, colocamos essa divisão ou classificação das ciências intelectuais num quadro sinótico, acrescentando, para fins didáticos, um nome a cada uma delas (das ciências) grafado em itálico, mas que não provém nem de Avicena, nem dos antigos e medievais, com o seu significado literal entre parêntesis:

\begin{tabular}{|c|c|c|}
\hline \multicolumn{3}{|c|}{ Classificação das Ciências Filosóficas especulativas superiores } \\
\hline \multicolumn{2}{|c|}{ Estrutura orgânica } & Campo de investigação \\
\hline \multirow{3}{*}{$\begin{array}{l}\text { Ciências } \\
\text { Intelectuais }\end{array}$} & $\begin{array}{c}\text { Ontologia } \\
\text { (Ciência do existente) }\end{array}$ & $\begin{array}{l}\text { Aplica-se ao conhecimento geral das coisas } \\
\text { existentes, ou das substâncias, em si mesmas. }\end{array}$ \\
\hline & $\begin{array}{c}\text { Etiologia } \\
\text { (Ciência das causas) }\end{array}$ & $\begin{array}{l}\text { Aplica-se ao conhecimento das causas } \\
\text { substanciais. }\end{array}$ \\
\hline & $\begin{array}{c}\text { Arquilogia } \\
\text { (Ciência dos princípios) }\end{array}$ & $\begin{array}{l}\text { Aplica-se ao conhecimento dos princípios } \\
\text { substanciais. }\end{array}$ \\
\hline
\end{tabular}




\begin{tabular}{|c|c|l|}
\hline Teologia & $\begin{array}{l}\text { Aplica-se ao conhecimento da causa e do } \\
\text { princípio absolutos identificados com o divino, } \\
\text { ou o existente necessário. }\end{array}$ \\
\hline
\end{tabular}

Partindo das informações transmitidas nesse segundo capítulo da obra aviceniana, podemos atualizar, ainda de modo provisório, a tabela da classificação das ciências filosóficas, como disposta ao fim do capítulo anterior do presente estudo:

\begin{tabular}{|c|c|c|c|c|}
\hline \multicolumn{5}{|c|}{ Classificação das Ciências Filosóficas III } \\
\hline \multicolumn{4}{|c|}{ Estrutura orgânica } & Campo de investigação \\
\hline \multirow{10}{*}{$\begin{array}{l}\text { Ciências } \\
\text { especulativas } \\
\text { (teóricas) }\end{array}$} & \multirow{4}{*}{ Superior } & \multirow{4}{*}{$\begin{array}{l}\text { Ciências } \\
\text { Intelectuais }\end{array}$} & $\begin{array}{l}\text { Teologia } \\
\text { (racional) }\end{array}$ & $\begin{array}{l}\text { Aplica-se ao conhecimento da } \\
\text { causa e do princípio absolutos } \\
\text { identificados com o divino. }\end{array}$ \\
\hline & & & Etiologia & $\begin{array}{l}\text { Aplica-se ao conhecimento das } \\
\text { causas substanciais. }\end{array}$ \\
\hline & & & Arquilogia & $\begin{array}{l}\text { Aplica-se ao conhecimento dos } \\
\text { princípios substanciais. }\end{array}$ \\
\hline & & & Ontologia & $\begin{array}{l}\text { Aplica-se ao conhecimento geral } \\
\text { das coisas existentes, ou } \\
\text { substâncias, em si mesmas. }\end{array}$ \\
\hline & Racional & \multicolumn{2}{|c|}{ Ciências Lógicas } & $\begin{array}{l}\text { Aplica-se ao conhecimento } \\
\text { racional de uma proposição pelo } \\
\text { juízo discursivo a se obter uma } \\
\text { conclusão. }\end{array}$ \\
\hline & \multirow{4}{*}{ Média } & \multirow{4}{*}{$\begin{array}{l}\text { Ciências } \\
\text { Doutrinais }\end{array}$} & Aritmética & $\begin{array}{l}\text { Aplica-se aos números absolutos } \\
\text { separados da matéria. }\end{array}$ \\
\hline & & & Geometria & $\begin{array}{l}\text { Aplica-se à medida dos corpos } \\
\text { imóveis. }\end{array}$ \\
\hline & & & Música & $\begin{array}{l}\text { Aplica-se às quantidades } \\
\text { numéricas relativas à matéria. }\end{array}$ \\
\hline & & & Astronomia & $\begin{array}{l}\text { Aplica-se à mediada dos corpos } \\
\text { móveis ou cósmicos. }\end{array}$ \\
\hline & Inferior & \multicolumn{2}{|c|}{ Ciências Naturais } & $\begin{array}{l}\text { Aplica-se ao conhecimento } \\
\text { teórico dos corpos no que se } \\
\text { refere ao movimento e suas } \\
\text { qualidades acidentais. }\end{array}$ \\
\hline \multicolumn{2}{|c|}{$\begin{array}{l}\text { Ciências ativas } \\
\text { (práticas) }\end{array}$} & $\begin{array}{l}\text { Ciências } \\
\text { Morais }\end{array}$ & \multicolumn{2}{|c|}{$\begin{array}{l}\text { Aplica-se ao conhecimento prático das ações } \\
\text { humanas individuais (ética) e sociais (política). }\end{array}$} \\
\hline
\end{tabular}




\section{Capitulo III:}

Qual a utilidade desta ciência, em que ordem ela deve ser estudada e qual a denominação mais conveniente a ela

Neste terceiro capítulo de nossa pesquisa, discorrer-se-á sobre a "utilidade" desta ciência filosófica, ou seja, a que fim é levado o estudante ao dedicar-se a este conhecimento; em relação às demais ciências filosóficas, em que momento ela deve ser estudada; e qual a denominação que melhor lhe convém.

O terceiro capítulo do Liber de Philosophia Prima sive Scientia Divina Tractatus Primus, "Livro referente à Primeira Filosofia ou Ciência Divina - Primeiro Tratado", vem intitulado De utilitate huius scientiae et ordine eius et nomine, cuja tradução literal é "A utilidade desta ciência, sua ordem e nome". O seu sentido já está exposto no parágrafo anterior e no título deste capítulo de nossa pesquisa. Passemos então à análise estrutural do texto aviceniano.

\section{III.1. Estrutura argumentativa}

Neste capítulo, podemos perceber a sequência de três pontos, já inicialmente expressos no título do capítulo:

a) A utilidade do estudo desta ciência;

$\checkmark \quad$ A utilidade das ciências em geral

$\checkmark$ As três divisões da utilidade (científica)

b) Em que ordem ela deve ser estudada;

$\checkmark$ Deve ser estudada após as ciências naturais e matemáticas

$\checkmark$ Objeções a esta ordem

$\checkmark$ Resposta às objeções

$\checkmark$ Outras observações

c) Qual a denominação mais conveniente.

$\checkmark$ Metafísica ou "Profísica" e o que se entende por "natureza"

$\checkmark$ Algumas observações

$\checkmark$ Metafísica ou Teologia

$\checkmark$ Considerações conclusivas

Desenvolvamos estes tópicos: 
No primeiro tópico, o autor, partindo da noção de utilidade, procura precisar em que sentido esta ciência em questão é útil; classificando, em seguida a utilidade em três modos, que se referem às relações de uma ciência com as outras.

No segundo tópico, o filósofo procura demonstrar que a ciência em questão deve ser estudada após a aquisição das demais, as naturais e as matemáticas, visto que supõe o conhecimento delas e, a partir disso, especula sobre seus fundamentos. Avicena levanta algumas possíveis objeções a isto e, em seguida, procura refutá-las.

No terceiro tópico, Avicena, a partir de tudo que foi dito, procura definir a denominação mais precisa e coerente desta ciência, focando, sobretudo, em duas expressões: ciência d'Aquilo que está após a natureza e Ciência Divina, comentando cada uma delas e justificando os nomes em relação às intenções da mesma.

Tendo dito isso, passemos agora à explanação temática apresentada pelos tópicos.

\section{III.2. Qual a utilidade do estudo desta ciência}

Para se compreender a utilidade desta ciência filosófica, é necessário compreender qual o conceito de utilidade e em que sentido esta ciência pode ser útil, por exemplo, às demais ciências. O filósofo parte de alguns conceitos já explanados em outros escritos anteriores. Sigamos o que ele diz:

Debes meminisse quod, in scientiis quae praecedunt hanc, iam cognovisti quae sit differentia inter utile et bonum et nocivum et malum, quoniam utile in se est occasio quae per se ducit ad bonum, utilitas vero est intentio quae perducit de malo ad bonum; nocivum vero in se est occasio quae per se ducit ad malum, nocumentum vero est intentio quae perducit de bono ad malum. ${ }^{70}$

Deves recordar que, nas ciências que precedem esta, já conheceste qual é a diferença entre o útil e o bem, o nocivo e o mal; porquanto o útil em si é ocasião que, por si, conduz ao bem; a utilidade é a intenção que leva do mal ao bem; o nocivo em si é ocasião que conduz, por si, ao mal; a nocividade é a intenção que leva do bem ao mal.

Avicena retoma algo que já foi dito anteriormente, citando as ciências que já foram estudadas antes da presente, que, de certo modo, já é uma resposta à ordem em que esta deve ser estudada. Mas não nos antecipemos às ideias. Ele supõe que o leitor se recorde da distinção, já feita, entre o útil e o bem, por um lado, e o nocivo e o mal, por outro. O

\footnotetext{
${ }^{70}$ Avicenna, op. cit., 18.
} 
útil é a situação que conduz ao bem, enquanto que o nocivo é a situação que conduz ao mal; sendo assim, a utilidade é a intenção que afasta do mal em vista do bem, enquanto a nocividade é a intenção que afasta do bem em vista do mal.

Assim sendo, saber a utilidade de uma ciência é conhecer o benefício que ela traz àquele que a adquire. Então, as questões iniciais que se colocam são: qual a utilidade das ciências em geral e, consequentemente, qual a utilidade desta ciência em questão em particular. Contudo, alguns esclarecimentos se fazem necessários. É o que Avicena procura fazer.

Neste parágrafo, Avicena reflete sobre a questão da utilidade das ciências em geral em sua relação umas com as outras e a situação específica desta ciência que busca estabelecer. Atentemos ao que diz:

Postquam autem hoc ita est, tunc iam scis quod omnes scientiae communicant in uma utilitate, scilicet quae est acquisitio perfectionis humanae animae in effectu praeparantis eam ad futuram felicitatem. Cum autem in principiis scientiarum inquiritur de utilitate earum, non est intentio earum perducendi ad hoc, sed ut adiuvent se adinvicem, ad hoc ut utilitas perveniat per quam certificetur scientia alia ab ea. Utilitas igitur secundum hanc intentionem dicitur absolute et dicitur proprie. Absolute scilicet, ut sit adducens ad certificationem alterious scientiae quocumque modo; proprie vero, ut sit adducens ad excellentiorem, quae est ei sicut finis quia est propter eam, sed non convertitur. Si igitur acceperimus utilitatem absolute, profecto haec scientia utilitatem habet. Sed si proprie, certe haec scientia adeo alta est quod ipsa non dignatur esse utilis aliis scientiis, ceterae vero scienttiae proficiunt in ea. ${ }^{71}$

Sendo assim, já sabes que todas as ciências têm em comum uma só utilidade, isto é, a aquisição da perfeição em efeito da alma humana preparando-a para a futura felicidade. Porém, quando se investiga nos princípios das ciências a sua utilidade, não se leva em conta a sua intenção, mas o auxílio mútuo, ou seja, a utilidade existe quando uma ciência adquire certeza [de seus princípios] a partir de uma outra. Portanto, a utilidade, segundo esta intenção, é dita próprio e absolutamente. Absolutamente, ou seja, levando, de qualquer modo, ao estado de certeza de outra ciência; propriamente, levando a uma maior excelência, que lhe é como o fim porque lhe é próximo, mas não se transforma. Portanto, se recebemos a utilidade absolutamente, seguramente esta ciência tem utilidade. Mas, se propriamente,

${ }^{71}$ Idem, 19. 
certamente esta ciência tão elevada é que ela própria não é digna de ser útil a outras ciências, na verdade, as outras ciências avançam nela.

Ao esclarecer a utilidade das ciências de modo geral, Avicena acaba por retomar aqui o que foi dito no início do primeiro capítulo explicitando-o com novas informações: a utilidade do conhecimento consiste no aperfeiçoamento da faculdade intelectiva da alma humana. Ora, a inteligência tem como fim o conhecimento da realidade, que consiste, em ralação à inteligência, na verdade. Ao conhecer, a alma adquire a perfeição de sua operação cognitiva, realizando-se e predispondo-se ao gozo ou satisfação deste aperfeiçoamento, que é o que Avicena (latino) chama de "felicidade", embora fosse mais exato falar de "beatitude"

De modo geral, a utilidade das ciências, quando especuladas a partir de seus princípios, se faz em relação às outras, no sentido de verificar, segundo Avicena, a certeza do princípio que fundamenta a investigação de uma outra. Neste sentido, Avicena observa que a utilidade de determinada ciência se faz de dois modos: próprio e absoluto, fazendo a seguinte distinção:

a) De modo absoluto quando determinada ciência estabelece como certo o princípio de outra;

b) De modo próprio quando a finalidade de uma ciência consiste em atingir a uma maior excelência, sem, contudo, se transformarem outra distinta.

No primeiro caso, a ciência em questão (Primeira Filosofia ou Ciência Divina) possui uma utilidade, visto que ela procede à certificação dos princípios de outras ciências (na condição de estes serem existentes). No segundo caso, porém, como Avicena afirma, por sua excelência, esta ciência está acima de ser útil às demais, mas, pelo contrário, as outras ciências tem o seu pleno desenvolvimento a partir dos resultantes da investigação.

Para nos aprofundarmos no assunto, atentemos ao que o autor diz sobre os tipos ou partes da utilidade.

Em seguida, Avicena distingue as partes em que a utilidade absoluta se divide, comentando brevemente sobre cada uma delas. Atentemos ao que ele escreve:

\footnotetext{
72 Observemos que o termo usado pelos tradutores latinos, felicitas, deriva de fecundus e está relacionado com a ideia de fecundidade da terra, dos rebanhos e do próprio homem em relação à geração dos filhos e, portanto, à prosperidade material. Mais apropriado seria usar o termo beatitudo, "beatitude", que consiste no estado permanente de perfeita satisfação e plenitude somente alcançado pelo sábio. Esse sentido filosófico condicionou posteriormente o uso teológico e religioso do termo na tradição cristã.
} 
Cum autem utilitas absoluta dividitur in suas divisionis, necessario dividitur in tria: quórum unum est id ex quo provenit aliud melius eo, aliud ex quo provenit aliud sibi aequale, aliud vero ex quo prevenit aliud inferius eo, et hoc, tertium prodest perfectioni eius quod est infra se. Cum vero inquisierimus nomen proprium huius tertii, convenientius est ut dicatur effluxio vel profectus vel dominatio vel procuratio vel alia his similia, cum fecerimus inductionem de dictionibus convenientioribus huic capitulo excepta causalitate. Utilitas autem própria paene servitus est, sed utilitas quae provenit ex nobiliore in ignobilius non est similis servituti. Tu enim scis quod serviens utilis est ei cui servit et ille cui servitur utilis est serviente, si utilitas accipiatur absolute; própria enim maneria cuiusque utilitatis et proprius modus eius est alia maneria. Utilitas igitur huius scientiae, cuius modum iam demonstravimus, est profectus certitudinis principiorum scientiarum particularium, et certitudo eorum quae sunt eis communia quid sint, quamvis illa non sint principia causalia. Est igitur sicut utilitas regentis ad id quod regitur, et sicut eius cui servitur ad servientem, quoniam comparatio huius scientiae ad alias scientias particulares est sicut comparativo eius cuius cognitio inquiritur in aliis scientiis. Sicut enim haec scientia est principium essendi illas, sic scientia huius est principium certitudinis sciendi illas. $^{73}$

Quando a utilidade absoluta é dividida em suas partes, necessariamente é dividida em três, das quais uma é aquela da qual provém outra melhor que ela; outra ainda da qual provém outra igual a si; uma terceira da qual provém outra inferior a ela, e esta é útil à sua perfeição que está abaixo de si. De fato, quando pesquisamos o nome próprio desta terceira, é mais conveniente que se diga escoamento, ou aperfeiçoamento, ou domínio, ou ocupação ou outro semelhante a estas, embora fizemos uma introdução sobre os discursos apropriados a este capítulo com exceção da causalidade. Porém, a própria utilidade é como uma servidão, mas a utilidade que provém do que é mais conhecido ao mais ignorado não se assemelha à servidão. Pois, tu sabes que o servente é útil a quem serve e aquele que é servido é útil ao servente, se a utilidade é recebida de modo absoluto; pois, a própria maneira de cada utilidade e o seu próprio modo é outra maneira. Portanto, a utilidade desta ciência, cujo modo já demonstramos, é o aperfeiçoamento da certeza dos princípios das ciências particulares e a certeza delas que lhes são comuns o que existam, embora elas não sejam princípios causais. Portanto, é como a utilidade do regente para com o que é regido, e como daquele a que é servido ao que serve, porque a comparação desta ciência a outras ciências particulares é como a comparação daquilo cujo

\footnotetext{
${ }^{73}$ Avicenna, op. cit., 19-20.
} 
conhecimento se investiga nesta ciência àquilo cujo conhecimento é investigado em outra ciência. Pois, como esta ciência é [sobre] o princípio do existir delas, assim, a ciência desta é o princípio da certeza da ciência delas.

Segundo Avicena, a utilidade absoluta de uma ciência é necessariamente dividida em três partes, a saber:

a) Aquela ciência da qual procede outra melhor;

b) Aquela da qual procede outra que lhe seja igual ou similar;

c) Aquela da qual procede uma ciência inferior e, portanto, esta última terá a primeira como causa de seu aperfeiçoamento. Avicena lhe dá as seguintes denominações: “escoamento", “aperfeiçoamento”, “domínio”, “ocupação” (etc.).

O fato de uma ciência ser útil à outra, segundo Avicena, é comparado a uma "servidão", porquanto uma ciência servir-se-á de outra para o seu próprio aperfeiçoamento. Todavia, ele exclui aquela ciência que parte do que é mais conhecido àquilo que é ignorado, afirmando que, neste caso, não há propriamente uma servidão, porquanto há uma mútua relação entre as ciências no que se refere à utilidade em que as duas são beneficiadas, cada uma à sua maneira.

Partindo do que foi dito, esta ciência é útil às demais no sentido de aperfeiçoar o conhecimento certo dos princípios das outras ciências particulares, isto é, o que é comum a todas: a existência de seus princípios, ainda que não sejam princípios causais. Sendo assim, o filósofo compara a utilidade da ciência intelectual à utilidade ou o serviço prestado por um regente àqueles que são regidos, ou seja, uma utilidade diretiva. Do mesmo modo, há uma gradação daquilo que se pesquisa nelas: a ciência intelectual estuda as coisas existentes e, ao verificá-las, dá a certeza destas que são princípios estudados pelas ciências particulares.

Em suma, o filósofo parte da noção de utilidade, que consiste na intenção que conduz do mal ao bem, procurando, em seguida, demonstrar em que sentido a ciência intelectual possui utilidade. Ora, a utilidade das ciências teóricas em geral, recordando o que já foi dito no primeiro capítulo, é aperfeiçoar a faculdade intelectiva pela aquisição do conhecimento, predispondo a alma para o deleite de sua realização que é a felicidade ou beatitude.

Em seguida, o autor afirma que há dois modos de as ciências serem úteis: próprio e absoluto. No primeiro, busca aperfeiçoar-se a si mesma, procurando atingir a excelência. No segundo, é útil às demais. Isso ocorre de três modos: em relação a uma 
ciência que lhe é superior; em relação a uma que lhe é similar; em relação a outra que lhe é inferior.

\section{III.3. Em que ordem ela deve ser estudada}

No que se segue, o autor tradada de questões didáticas, orientando a ordenação do aprendizado da ciência em questão. De fato, o modo como ele estrutura sua obra já é, por si, a ordem recomendada para a instrução. Contudo, o autor pretende justificar essa ordem, expondo, inclusive, as objeções a essa escolha e respondendo a elas. Sigamos o seu raciocínio.

No parágrafo a seguir, Avicena propõe que as ciências intelectuais sejam estudadas após as ciências naturais e matemáticas. Embora trate dos princípios delas, o conhecimento daquilo que ela trata se dá supondo o conhecimento adquirido pelo estudo das demais, porquanto não se trata da ordem das coisas em si, mas da ordem da intelecção humana, que parte dos sensíveis aos inteligíveis. Atentemos ao que ele expõe:

Ordo vero huius scientiae est ut discatur post scientias naturales et disciplinales. Sed post naturales, ideo quia multa de his quae conceduntur in ista sunt de illis quae iam probata sunt in naturali, sicut generatio et corruptio, et alteritas, et locus, et tempus, et quod omne quod movetur ab alio movetur, et quae sunt e aquae moventur ad primum motorem, et cetera. Poste disciplinales vero, ideo quia intentioultima in hac scientia est cognitio gubernationis Dei altissimi, et cognitio angelorum spiritalium et ordinum suorum, et cognitio ordinationis in circulorum, ad quam scientiam imposssibile est perveniri nisi per cognitionem astrologiae; ad scientiam veroastrologiae nemo potest pervenire nisi per scientiam arithmeticae et geometriae. Musica vero et particulares disciplinalium et morales et civiles utiles sunt, non necessariae, ad hanc scientiam. ${ }^{74}$

$\mathrm{Na}$ verdade, a ordem desta ciência é que se estude após as ciências naturais ${ }^{75} \mathrm{e}$ matemáticas. Mas, após as [ciências] naturais, até porque muitas destas que são admitidas nesta [ciência] tratam daquilo que já foi considerado na [ciência] natural, como a geração e a corrupção, a alteridade, a localidade, o tempo, e tudo aquilo que se move a partir de outro que é movido e que são os que se movem pelo primeiro motor e assim por diante. De fato, após as matemáticas, até porque a intenção última nesta ciência é o conhecimento do governo do Deus altíssimo, o conhecimento dos

\footnotetext{
${ }^{74}$ Idem, 20-21.

${ }^{75}$ Grafamos esta expressão pelo fato de, embora não ser a expressão que traduz a expressão grega $\tau \grave{\alpha} \mu \varepsilon \tau \grave{\alpha}$

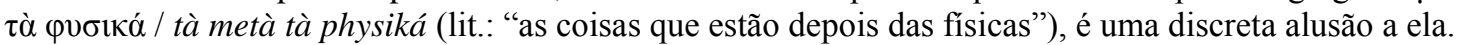


anjos espirituais e de suas ordens, o conhecimento da ordenação na composição dos círculos, a qual ciência é impossível ser alcançada a não ser pelo conhecimento da Astrologia; de fato, não se pode atingir a ciência da Astrologia a não ser pela ciência da Aritmética e da Geometria. A Música e as outras disciplinas matemáticas, as morais e civis são úteis, não necessárias, a esta ciência.

Portanto, Avicena estabelece que a ciência em questão seja estudada após as ciências naturais e matemáticas (que aqui está sendo tratada, em latim, de disciplinalis e não de doctrinalis como até então ocorria). O seu argumento é que aquilo que já foi estudado nas ciências naturais e matemáticas é suposto pelas intelectuais, por exemplo, a questão do movimento: todo movido tem seu motor que sucessivamente atinge ao primeiro motor (imóvel); este será especulado pelas intelectuais (no caso a etiologia, por exemplo) como causa primordial do movimento do universo. Outro exemplo, ligado às matemáticas, o conhecimento da ordenação na composição dos círculos (pensemos nas esferas celestes) cuja especulação se fundamenta no conhecimento adquirido pela Astrologia ${ }^{76}$ que, por sua vez, se funda na Aritmética e na Geometria.

Avicena conclui o parágrafo afirmando que as outras ciências matemáticas, como a Música, ou as ciências morais e civis, ou seja, a Ética e a Política, são úteis às ciências intelectuais, embora não sejam necessárias à sua especulação, como é o caso das naturais ou a Astrologia, como foi dito.

Contudo, Avicena levanta algumas objeções que poderiam ser propostas ao fato de colocar as ciências intelectuais como últimas a serem estudas pelo iniciante nas artes filosóficas. Tratando elas dos princípios das demais, não deveria ser estudada em primeiro lugar? Atentemos ao que ele diz:

Potest autem aliquis opponere dicens quod, si principia scientiae naturalis et disciplinalium non probantur nisi in hac scientia et quaestiones utrarumque scientiarum probantur per principia earum, quaestiones vero earum fiunt principia huius, tunc haec argumentatio est circularis et per ultimum eius fit manifestatio sui ipsius. $^{77}$

Porém, alguém pode se opor dizendo que, se os princípios da ciência natural e das disciplinares [matemáticas] não são examinados a não ser nesta ciência e as questões de ambas as ciências são examinadas pelos princípios delas, na verdade, as questões

\footnotetext{
${ }^{76}$ Neste caso, o mesmo que Astronomia. Nesse momento, não há uma distinção clara entre Astronomia e Astrologia como fazemos hodiernamente.

${ }^{77}$ Avicenna, op. cit., 21.
} 
delas se tornam princípios desta [ciência], então esta argumentação é circular e, pelo seu fim, torna-se manifestação de si mesma.

Avicena levanta uma hipotética objeção à ordem proposta de estudo das ciências filosóficas que é a seguinte: os princípios das ciências naturais e matemáticas são examinados e verificados pelas ciências intelectuais; ora, são por meio desses princípios que as ciências naturais e matemáticas examinam suas questões; logo, as questões de ambas se converteriam em princípios das ciências intelectuais, o que redundaria num círculo vicioso.

Às objeções levantadas, o filósofo retoma o que já escrevera no Livro das demosntrções, como ele mesmo indica, afirmando ser o suficiente para refutá-las. Atentemos ao que diz:

Contra hoc autem verisimule debet responderi id quod dictum est iam et ostensum est in Libro demonstrationis, de quo tamen nos repetemus hic quod sufficiet. Dico igitur quod principium scientiae non est principium sic ut omnes quaestiones pendeant ex eo ad demonstrandum eas in actu vel potentia, sed fortasse accipietur principium in demonstratione aliquarum. Possibile est etiam esse quaestiones in scientiis in quarum domonstrationibus non admittuntur ea quae posita sunt principia ullo modo, quia non admittuntur nisi propositiones quae non probantur ad hoc ut principium verissimum, per quod ad ultimum acquiratur certíssima veritas, sicut est illa quae acquiritur ex causa. Si autem non acquirit causam, non dicetur principium scientiae sic sed aliter, quia fortasse dicetur principium, sicut sensus solet dici principium, eo modo quo sensus inquantum est sensus, non acquirit nisi esse tantum. Soluta est igitur quaesito, quoniam principium naturale potest esse manifestum per se, et potest esse ut manifestatur in philosophia prima per id per quod non fuerat probatum antea, sed per quod in illa probantur aliae quaestiones ita, quod est propositio in scientia altiori ad inferendum in conclusione illud principium, non in hoc assumatur principium ad concludentem illud, sed assumatur alia propositio. Possibile est etiam ut scientia naturalis et disciplinalis acquirant nobis demonstrationem de quare est, sed haec scientia acquirit nobis demonstrationem de quare est, et praecipue in causis finalibus remotis. Manifestum est igitur quod de quaestionibus sscientiae naturalis id quod est principium huius scientiae aliquo modo, vel non manifestabitur ex principiis quae manifestantur in hac scientia, sede ex principiis quae sunt per se nota, vel manifestabitur ex principiis quae sunt quaestiones in hac scientia, sed non convertuntur ut fiant principia illarum earundem quaestionum sed aliarum, vel illa principia erunt principia aliquorum 
huius scientiae quae significarunt illud esse de quo quaeritur manifestari in hac scientia quare est. Constat igitur quod, cum ita sit, non erit praedicta probatio circularis ullo modo, ita ut ipsa sit probatio in qua aliquid idem accipiatur in probatione sui ipsius. ${ }^{78}$

Portanto, contra esta provável [objeção], deve-se responder o que já se disse e se expôs no Livro da demonstração, do qual também nós repetimos isto que é suficiente. Portanto, afirmo que o princípio de uma ciência não é o princípio, assim como todas as questões dependem dele a fim de demonstrá-las em ato ou em potência, mas talvez receber-se-á o princípio na demonstração de algumas [ciências]. Também é possível existir questões nas ciências, em demonstrações das quais não se admitam aqueles princípios que são dispostos de algum modo, porque não se admitem a não ser as proposições que não são examinadas e que o princípio da ciência seja o mais verdadeiro princípio, através do qual ao fim se atinge a verdade certíssima, como aquela que se adquire a partir da causa. Portanto, se não adquire a causa, não se dirá o princípio da ciência, mas de outro modo diferente, porque talvez se dirá princípio, do mesmo modo que se costuma dizer de "ideia", princípio; pelo modo que "ideia", enquanto é "ideia", não se adquire senão somente pela existência. Portanto, a questão foi resolvida, visto que o princípio natural pode revelar-se por si e pode ser que seja manifestado na Primeira Filosofia por aquilo através do qual não fora examinado antes, mas por aquilo que naquela [ciência] são examinadas outras questões, pois que é a proposição na ciência mais alta, a fim de inferir uma conclusão àquele princípio, não é tomado nisto o princípio para se concluir aquilo, mas é tomada outra proposição. Também é possível que a ciência natural e disciplinar [matemática] adquiram para nós a demonstração sobre o "se existe" e não adquiram a nós a demonstração sobre o "porquê existe", mas esta ciência adquire para nós a demonstração sobre o "porquê existe", e sobretudo nas causas finais remotas. Portanto, reconhece-se que sobre as questões da ciência natural o que é princípio desta ciência, de algum modo, ou não será manifestado a partir dos princípios que são manifestados nestas ciências, mas a partir dos princípios que são notados por si; ou se manifestará a partir dos princípios que são questões nesta ciência, mas não se transformam a fim de se tornarem princípios daquelas mesmas questões, mas de outras; ou aqueles princípios serão princípios de outras [questões] desta ciência que indicam aquela existência da qual se procura manifestar-se nesta ciência pelo que existe. Portanto, consta que, quando assim é, não será conhecido o exame circular

${ }^{78}$ Idem, 21-23. 
por aquele modo, assim como o próprio exame exista naquela [ciência], de certo modo, a mesma seja recebida no exame de si própria.

O filósofo começa por argumentar que o princípio de uma ciência não é necessariamente o princípio em sentido absoluto, pois ele poderá ser demonstrado por outra ciência, que o tenha como objeto de investigação e não como princípio. Sendo assim, segundo ele, podem haver questões em determinadas ciências que não admitam princípios de outras simplesmente pelo fato de admitirem somente as proposições que foram examinadas e que se fundamentam em princípios de suma veracidade mediante o qual se pode alcançar a certeza e a verdade como se alcança um conhecimento a partir de sua causa.

Desse modo, conforme o autor, se não atingir o conhecimento da causa, então, não se pode entender como princípio de uma ciência, mas deverá se compreender isso de outra maneira; segundo Avicena, o que se entende por "princípio" consiste, nesse caso, numa “ideia", não na causa de um existente, mas na sua ideia que se adquire mediante o conhecimento de um existente.

Com isso, o filósofo considera refutada as objeções levantadas ao afirmar que o princípio das coisas naturais (princípio natural) ou se manifesta por si mesmo, ou se alcança o seu conhecimento através da especulação realizada na Primeira Filosofia sobre aquilo que não havia sido, até então, investigado. Segundo ele, a referência mediante a qual são examinadas as outras questões, que consiste na proposição da mais alta ciência - isto é, da Metafísica - em vista de chegar à conclusão que parte da especulação de um determinado princípio, não é assumida como princípio a fim de se concluir algo, mas é tomada uma outra proposição e, portanto, não redunda em círculo vicioso.

Avicena afirma ainda que, pelas ciências naturais e matemáticas, podemos conhecer se algo de fato existe, mas elas não podem nos informar a razão de sua existência, resposta esta que cabe à ciência metafísica especular, fazendo-nos conhecer as últimas causas das coisas existentes. No referente às relações com questões das ciências naturais, por exemplo, o autor faz três observações:

a) O princípio da ciência metafísica não é cognoscível a partir dos princípios das ciências naturais, mas seu conhecimento é possível a partir dos princípios que são conhecidos por si mesmos, não necessitando de serem demonstrados em razão de sua evidência; 
b) O princípio da ciência metafísica é cognoscível a partir dos princípios que são questões a serem investigadas na ciência metafísica, sem, contudo, suas conclusões se converterem em princípios das mesmas questões, e sim, de outras;

c) Esses mesmos princípios são princípios de outras questões investigadas nesta ciência metafísica que, por sua vez, referem-se às coisas existentes cognoscíveis por esta ciência mediante a própria existência da coisa em si.

Sendo assim, com essa argumentação, o filósofo refuta as objeções de redundar em círculo vicioso, distinguindo as relações dos princípios e questões a serem especuladas pelas ciências intelectuais, matemáticas e naturais. Passemos agora a outras observações de Avicena.

A resposta a suposta objeção é retomada de um tratado anterior intitulado Livro da demonstração.

Debes etiam scire quod in ipsis rebus est via qua ostenditur quod intentio huius scientiae non est ponere aliquid esse principium nisi postquam probatum fuerit in alia scientia. Postea vero manifestabitur tibi innuendo quod nos habemus viam ad stabiliendum primum principium, non ex via testificationis sensibilium, sede ex via propositionum universalium intelligibilium per se notarum, quae facit necessarium quod ens habet principium quod est necesse esse, et prohibet illud esse variabile e multiplex ullo modo, et facit debere illud esse principium totius, et quod totum debet esse per illud secundum ordinem totius. Sed nos propter infirmitatem nostrarum animarum non possumus incedere per ipsam viam demonstrativam, quae est progressus ex principiis ad sequentia et ex causa ad causatum, nisi in aliquibus ordinibus universitatis eorum quae sunt, sine discretione. Igitur ex mérito huius scientiae in se est, ut ipsa sit altior omnibus scientiis; quantum vero ad nos posterioratur post omnes scientias. Iam igitur locuti sumus de ordine huius scientiae inter omnes scientias. ${ }^{79}$

Deves saber, porém, que nas próprias coisas existe uma via pela qual se expõe porque a intenção desta ciência não é colocar, de certo modo, o princípio da existência, a não ser depois que será considerado em outra ciência. Em seguida, te é manifestado indicando que nós temos uma via para estabelecer o primeiro princípio, não a partir da via da atestação dos sentidos, mas a partir da via das proposições universais inteligíveis conhecidas por si, que faz necessário que o existente tenha um princípio que é necessariamente a existência e impede aquela existência variável e múltipla de

${ }^{79}$ Idem, 23-24. 
algum modo e faz dever aquela existência o princípio de tudo, que tudo deve existir por ela segundo ordem do todo. Mas nós, em razão da enfermidade de nossas almas, não podemos iluminar através do próprio caminho demonstrativo, que é desenvolvido a partir dos princípios às coisas que se seguem e a partir da causa ao causado, exceto em algumas ordens da universalidade daquelas coisas que existem sem distinção. Portanto, a partir do mérito desta ciência existe em si e a fim de que ela seja a mais alta de todas as ciências; o quanto, na verdade, para nós está além de todas as ciências. Portanto, já falamos sobre a ordem desta ciência entre todas as ciências.

Recapitulando com o leitor, o autor faz duas observações que devem ser evidentes após tudo que já se disse:

a) Pelas próprias coisas se conhece que não é intenção da ciência metafísica estabelecer o princípio da existência, exceto no que se refere àquilo que será estudado nas demais ciências;

b) Que o autor dispõe do método de se estabelecer o primeiro princípio mediante as proposições universais inteligíveis, cujo conhecimento é evidente por si e não mediante a percepção sensível, ou seja, que haja um existente cuja existência seja um princípio necessário, que seja despojado de variação e multiplicidade, isto é, seja imóvel e uno, e que seja o princípio do existir de todos os existentes em sua ordem.

Contudo, o filósofo reconhece que, "pela enfermidade das almas", isto é, pelos limites da razão ou do intelecto humano, não é possível fazer a demonstração das coisas a partir de seus princípios ou causas, ou seja, explicar os efeitos a partir de seus fundamentos (mas exatamente o contrário, se demonstra os fundamentos a partir dos seus efeitos resultantes), excetuando aquelas coisas cujos resultantes e resultados não são separados, mas subsistem numa mesma realidade.

Avicena conclui esse raciocínio recordando que esta ciência metafisica possui reconhecimento em si mesma, visto que é a mais alta das ciências filosóficas, e assim deve ser por nós reconhecida, como aquela ciência que está além de todas as ciências, recordando, inclusive, sobre a ordem na qual ela deve ser estudada, o que demonstra sua relação com as demais.

Em suma, Avicena procura justificar a ordem em que esta ciência é estudada, isto é, após as ciências lógicas, naturais e matemáticas, como afirmara logo no início desta obra em questão. Entretanto, as ciências intelectuais são tidas como aquelas que tratam 
dos fundamentos das demais ciências, ou de seus princípios. Sendo assim, pareceria mais lógico que ela fosse estudada antes das demais, pois, ao se verificar os seus respectivos princípios, poderia, então, estudá-las com mais propriedade.

Isso é correto no que diz respeito à realidade das coisas em si mesmas, ou seja, de modo objetivo. Todavia, o conhecimento se dá no plano subjetivo, ou seja, a partir do sujeito cognoscente, que parte da percepção das realidades sensíveis e, por raciocínio indutivo, chega ao conhecimento de suas causas. Sendo assim, o conhecimento de algumas partes das ciências naturais e matemáticas são pressupostos necessários para a aquisição do conhecimento dos inteligíveis.

Contudo, uma objeção pode ser levantada: visto que as ciências intelectuais examinam e verificam os fundamentos das ciências naturais e matemáticas, mediante as quais elas examinam suas próprias questões, estas, por sua vez, não se converteriam em princípios das ciências intelectuais, redundando em círculo vicioso?

Avicena refuta essa objeção afirmando que aquilo que fundamenta uma ciência não consiste necessariamente num princípio absoluto, podendo, assim, ser investigado por outra ciência que não o tenha como princípio. Afirma, ainda, que os princípios de algumas ciências não podem ser admitidos em questões examinadas por outras se não tiverem sua veracidade e certeza demonstrada como um conhecimento proveniente de uma causa. Nesse sentido, não se deve falar propriamente de um princípio, senão em sentido genérico, mas de uma ideia proveniente da percepção de um existente. De modo que os princípios das ciências naturais ou se reconhecem por si mesmos, ou são descobertos pela investigação das ciências naturais, sendo errôneo considerar as questões destas como princípios das intelectuais, não redundando em círculo vicioso.

Por fim, demonstra que, pelos limitas próprios da razão, não é possível à esta ciência em questão alcançar a intelecção das realidades inteligíveis por elas mesmas, ou intuir os primeiros princípios sem que se use a indução a partir dos efeitos percebidos. Passemos agora à questão da denominação da ciência em questão.

\section{III.4. Qual a denominação mais conveniente}

No decorrer dos dois capítulos anteriores, o filósofo apresentou várias qualificações e nomes para se referir à esta ciência filosófica: Ciências intelectuais, Primeira Filosofia, Ciência Divina, Sapiência, não tomando nenhuma dessas expressões por nomes formais. Na primeira expressão, por exemplo, indica-se até mesmo um conjunto de ciências, como as matemáticas e as naturais, com suas respectivas divisões 
não necessariamente nomeadas. No seguinte tópico, ele discutirá a respeito da nomenclatura adequada, focando sobretudo em dois nomes: ciência d'Aquilo que está após a natureza (Metafísica) e Ciência Divina (Teologia). Sigamos o seu raciocínio.

\section{a) Metafisica ou "Profisica" e o que se entende por "natureza"}

Neste parágrafo, Avicena especula o nome genérico desta ciência sob dois aspectos: a) sob a perspectiva de nossas percepções; b) sob aquilo que ela é em si mesma; e aproveita a oportunidade para dar uma breve conceptualização de "natureza". Atentemos ao que ele diz:

Nomen vero huius scientiae est quod ipsa est de eo quod est post naturam. Intelligitur autem natura virtus quae est principium motus et quietis, immo et universitas eorum accidentium quae proveeniunt ex materia corporali est virtus. Iam autem dictum est quod natura est corporis naturalis quod habet natturam. Corpus vero naturale est corpus sensibile cum eo quod habet de proprietatibus et accidentibus. Quod vero dicitur post naturam, hoc posteritas est in respectu quantum ad nos: primum enim quod percipimus de eo quod est et scimus eius dispositiones est hoc quod praesentatur nobis de hoc esse naturali. Unde quod meretur vocari haec scietia, considerata in se, hoc est ut dicatur quod est scientia de eo quod est ante naturam, ea enim de quibus inquiritur in hac scientia per essentiam sunt ante naturam. ${ }^{80}$

Na verdade, o nome desta ciência é: que ela é sobre aquilo que está após a natureza. Por natureza se entende a força que é princípio de movimento e repouso, ou melhor, é a força da totalidade de seus acidentes que provém da matéria corporal. De fato, já foi dito que natureza é do corpo natural que tem natureza. $\mathrm{Na}$ verdade, o corpo natural é corpo sensível como por aquele que possui [natureza] a partir das propriedades e acidentes. Portanto, o que se diz após a natureza, esta posteridade é em respeito quanto a nós, pois, o primeiro que percebemos daquele que existe e conhecemos de suas disposições é isto que se nos apresenta a partir desta existência natural. Donde o que esta ciência merece ser chamada, considerada em si, como se dissesse que é a ciência a partir daquilo que está antes da natureza; pois, aquelas coisas sobre as quais se investigam nesta ciência através da essência e através da ciência existem antes da natureza. ${ }^{81}$

O nome proposto por Avicena a esta ciência em questão não se reduz a um termo único, mas se expressa por uma locução: de eo quod est post naturam, "sobre aquilo que

\footnotetext{
${ }^{80}$ Avicenna, op. cit., 24-25.

${ }^{81}$ Os grifos são nossos.
} 
ما بعد الطبعة está após a natureza". Esta locução corresponde literalmente ao original arábico I mā ba'd at-tabi 'a, "o que está depois da natureza", que, por sua vez, consiste numa

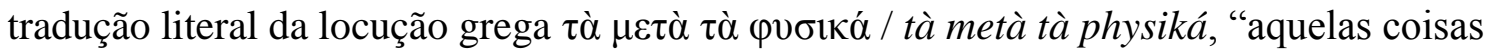
que estão depois das físicas". ${ }^{82}$ Esta locução grega foi entendida pela tradição filosófica arábica como se tratando das "coisas existentes que se percebem depois das coisas naturais".

A partir disso, Avicena procura esclarecer no que consiste natureza. Ele diz que natureza é "a força que é princípio de movimento e repouso, ou melhor, é a força da totalidade de seus acidentes que provém da matéria corporal”. Em outras palavras, a natureza consiste no princípio operativo das coisas existentes materiais e corpóreas manifestadas pelas qualidades intrínsecas (acidentes) das mesmas. E, portanto, a natureza é própria, segundo Avicena, do “corpo natural”, isto é, do corpo sensível dotado de suas propriedades e acidentes e que podem ser percebidas através dos sentidos anímicos.

Portanto, como só percebemos pelos sentidos anímicos as qualidades e disposições sensíveis provenientes da natureza ou do corpo natural e somente, a partir disso, é que podemos apreender os inteligíveis, por essa razão, Avicena afirma que é sob nosso ponto de vista que se trata de um conhecimento do que é após a natureza. Entretanto, na sequência da reflexão de Avicena, se for considerar as coisas essenciais em si mesmas que são tratadas pelas ciências intelectuais, elas são anteriores e o próprio fundamento das coisas naturais, então, esta ciência deveria ser, segundo o filósofo, daquelas coisas que existem antes da natureza. ${ }^{83}$

Seguem-se algumas observações referentes a supostas objeções que podem ser levantadas. Atentemos ao que diz:

Potest autem aliquis decere quod res disciplinales purae, quas speculatur arithmetica et geometria, sunt etiam ante naturam, et praecipue numerus cuius esse

\footnotetext{
${ }^{82}$ A origem dessa locução foi atribuía a Andrônico de Rodes (séc. I a.C.), responsável pela organização, catalogação e publicação das obras de Aristóteles e seu divulgador entre os romanos. Segundo antigos relatos, Andrônico intitulou com a citada locução doze tratados aristotélicos reunidos num único códice e dispostos, conforme a classificação que estabelecera, após os tratados das ciências físicas. Sendo assim, a

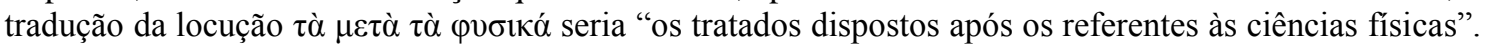
O fato é que o termo Metaphysika foi usado pelos helenistas e bizantinos como nome próprio da obra de Aristóteles. O mesmo ocorreria mais tarde na Europa ocidental quando a obra aristotélica foi vertida ao latim por Giacomo de Veneza (séc. XII). Na tradição arábico-latina (esta última por influência de Avicena), o termo Metaphysica passaria a indicar o nome da ciência filosófica (como estamos vendo), cujo uso paulatinamente se generalizaria a partir do séc. XIII em diante na filosofia ocidental.

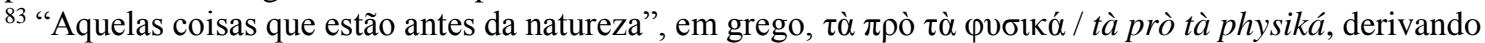
daí o nome "Profísica", ou seja, não daquilo que está além da natureza (metafísica), mas sim, daquilo que está aquém da natureza (profísica).
} 
non pendet ex natura ullo modo: invenitur enim in non natura. Igitur scientia de numero debet esse scientia post naturam. Quod igitur debemus dicere contra hanc quaestinem, hoc est quod in geometria, si quicquid speculamur de illa, non fuerit nisi in lineis, superficiebus et corporibus. Constat tunc quod subiectum eius non erit separatum a natura in existentia; igitur accidentia quae comitantur illud minus remota erunt ab ea. Sed si fuerit subiectum eius mensura absoluta, vel id in quo invenitur mensura absoluta sic ut adaptabile sit cuilibet proportioni, hoc certe non est mensurae inquantum est principium naturalium et forma, sed inquantum est accidens. Iam autem cognita est ex his quae diximus in logicis et naturalibus differentia inter mensuram absolutam, quae est post hyle, et inter mensuram quae est quanta, et quod nomen mensurae convenit eis communiter. Cum igitur hoc ita sit, tunc non erit subiectum geometriae verissimum mensura quae constituit corpus naturale, sed mensura quae dicitur de linea, superficie et corpore; et hoc est quod adaptari potest proportionibus diversis. ${ }^{84}$

Porém, alguém pode dizer que as coisas disciplinares puras, que a Aritmética e a Geometria especulam, também existem antes da natureza, e sobretudo o número cuja existência não depende da natureza por algum modo; pois investiga-se em nãonatureza. Portanto, a ciência sobre o número [Aritmética] deve ser ciência após a natureza [metafísica]. Portanto, o que devemos dizer contra esta questão, isto é, que na Geometria, se especulamos algo sobre ela, não fará a não ser em linhas superficiais e corpóreas. Então, é certo que seu objeto formal não será separado da natureza na subsistência; portanto, os acidentes que o acompanham estarão menos distantes dela. Mas se o objeto formal dela for uma medida absoluta, ou aquilo no qual se encontra uma medida absoluta como é adaptável de qualquer proporção, isto certamente não é da medida enquanto é princípio das naturezas e forma, mas enquanto é acidente. Isto já é conhecido daquilo que dissemos nas [ciências] lógicas e naturais a diferença entre medida absoluta, que é após a hylé, e entre medida quanta, e que o nome de medida geralmente lhe convém. Portanto, como isto é assim, não será o objeto formal da Geometria a mais verdadeira medida que constitui um corpo natural, mas medida que se diz sobre a linha, a superfície e o corpo; é isto que se pode adaptar por diversas proposições.

Avicena propõe algumas possíveis objeções ao que até então afirmou: não existiriam antes da natureza as coisas matemáticas puras, especuladas pela Aritmética e pela Geometria, principalmente o número cuja existência é totalmente separada da

\footnotetext{
${ }^{84}$ Avicenna, op. cit., 25-26.
} 
natureza, cujo estudo se realiza nesta de não-natureza? Por esta razão, sob nosso ponto de vista, não seriam essas ciências matemáticas também elas ciências metafísicas?

No que se refere à Geometria, não se pode afirmar que esteja totalmente desligada das coisas naturais, pois sua especulação se faz a partir de linhas nas superfícies das coisas corpóreas e, portanto, relacionadas com coisas naturais subsistentes e próximas aos seus acidentes. Em linhas gerais, a própria medida, em si mesma, depende, de certo modo, da matéria corpórea subsistente.

\section{b) Metafísica ou Teologia}

No parágrafo a seguir, Avicena coloca algumas dificuldades que possam surgir no entendimento do nome Metafísica, levando a confusão das intenções desta ciência filosófica com a ciência dos números (Aritmética). A partir disso, procura delimitar e precisar as intenções e a nomenclatura desta ciência intelectual por aquilo que há de mais excelente nos existentes investigados, o divino, preferindo a denominação de Ciência Divina (Teologia). Atentemos ao que ele diz:

De numero autem maior est quaestio, quoniam videtur superfície tenus quod scientia de numero sit de scientia post naturam, nisi scientia post naturam intelligatur aliud, scilicet quod est scientia de eo quod omnimodo separatum est a natura, et nunc nominabitur haec scientia ab eo quod est dignius in ea, scilicet vocabitur haec scientia, scientia divina: cognitio enim Dei finis est huius scientiae; multae enim res appellantur ab eo quod est in eis dignius, vel a parte digniore, vel a parte quae est eis quase finis. Erit igitur haec scientia quasi cuius perfectio et cuius pars aliqua nobilior et cuius prima intentio est cognitio eius quod separatum est a natura omnimodo. Cum igitur appellata fuerit secundum hanc intentionem, tunc scientia de numero non communicabit intentioni huius nominis hoc modo. ${ }^{85}$

Porém, maior é a questão sobre o número, porque vê-se pela superfície somente que a ciência sobre o número [Aritmética] seja da ciência após a natureza [metafísica]; a não ser que por ciência após a natureza [metafísica] se entenda outra coisa, isto é, que é a ciência sobre aquilo que, de qualquer modo, está separado da natureza, então esta ciência é denominada a partir daquilo que é mais digno nela, ou seja, esta ciência é chamada de Ciência Divina: pois, o conhecimento de Deus é o fim desta ciência; pois, muitas coisas são chamadas a partir daquilo que é mais digno nela, ou da parte mais digna, ou da parte que lhes é como o fim. Portanto, será esta ciência, por assim

${ }^{85}$ Idem, 26. 
dizer, cuja perfeição, cuja parte mais nobre, cuja primeira intenção é o conhecimento daquele que é, de qualquer modo, separado da natureza. Portanto, quando for chamada segundo essa intenção, a ciência sobre o número não terá em comum as intenções deste nome por este modo.

Segundo Avicena, já numa visão superficial, a Aritmética, ou "ciência sobre os números", também se apresenta como uma ciência após a natureza (metafísica). Sendo assim, Avicena sugere que a Metafísica, para ser chamada desse modo, seja compreendida de outra maneira, isto é, que ela seja compreendida como uma ciência que trata das coisas separadas da natureza. Nesse sentido, segue o autor, ela receberá sua denominação a partir daquilo que é considerado mais digno por ela tratado e que constitui o último fim desta ciência: Deus ou o Divino, "pois, muitas coisas são chamadas a partir daquilo que é mais digno nela, ou da parte mais digna, ou da parte que lhes é como o fim”. Desse modo, o filósofo afirma que ela deva ser chamada de Ciência Divina, tradução literal da expressão

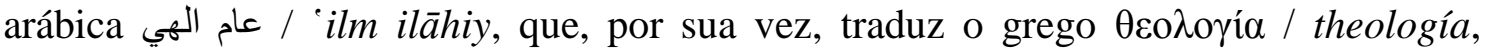
"discurso de deus", "discurso sobre deus" e, por extensão, "ciência divina".

Portanto, a Metafísica será chamada de Ciência Divina ou Teologia em função de tratar do "existente divino", por assim dizer, não somente por ser o que há de mais nobre e perfeito na existência, mas também por ser aquele que está totalmente separado da natureza, que consiste na primeira intenção desta ciência filosófica. Sendo assim, não haverá risco de confundir, pela denominação, esta ciência com a ciência dos números, a Aritmética, visto que suas intenções são claramente diferentes.

Passemos agora à conclusão do capítulo.

Sed manifestatio veríssima qua probatur scientia de numero non esse de scientia post naturam, haec est: constat enim quod subiectum euis non est numerus omnimodo. Numerus enim iam invenitur in rebus separatis, et iam invenitur in rebus naturalibus, et iam contingit ipsum poni in aestimatione exspoliatim ab omni quod sibi accidit, quamvis non sit possibile numerum esse, nisi accidat alicui eorum quae sunt. Id autem quod de numero fuerit tale cuius esse sit in rebus separatis, illud prohibebitur esse subiectum proportionis cuiuslibet in augmento et diminuitione, sed erit secundum quod est tantum. Non enim potest concedi ipsum sic poni receptibilem cuiuslibet augmenti et cuiuslibet proportionis, nisi cum fuerit in materia corporum quae in potentia est omnis maneria numeratorum; et tunc cum fuerit in aestimatione vel in utrisque dispositionibus, est non separatus a natura. Igitur scientia de numero, inquantum considerat numerum, non speculatur in eo nisi secundum respectum quo 
accidit ei esse in natura, quia videtur quod principium suae considerationis, secundum quod ipse est in aestimatione, sit huiusmodi quod aestimatio sit accepta ex dispositionibus naturalibus quae habent aggregari et digregari, uniri et dividiri. Unde scientia de numero non est speculatio de essentia numeri nec de accidentibus numeri inquantum est numerus absolute, sed de accidentalibus eius inquantum fit receptibilis humanus innixus materiae. Speculatio vero de esssntia numeri et de eo quod accidit ei secundum quod non pendet ex matéria nec est innixus in ea, est in hac scientia. ${ }^{86}$

Mas a manifestação mais verdadeira pela qual se examina a ciência sobre o número não é a partir da ciência após a natureza [metafísica], isto é, pois consta que o objeto formal dela, de qualquer modo, não é o número. Pois, o número se encontra tanto nas coisas separadas [da matéria], como também se encontra nas coisas naturais, e atinge o mesmo que se dispõe na estimação despojada de tudo que lhe acontece, embora não é possível existir o número, a não ser que ocorra em alguns deles que existam. Porém, aquilo que do número fora tal cuja existência esteja nas coisas separadas [da matéria], proibir-se-á aquilo ser o objeto formal de qualquer proporção em argumento e diminuição, mas será conforme o que simplesmente existe. Pois não se pode admitir que ele próprio, desse modo, se coloque receptível de qualquer argumento e de qualquer proporção, a não ser enquanto estiver na matéria dos corpos que está em potência toda maneira dos que contam; e então, embora estivesse na estimação ou em uma outra disposição, não é separado da natureza. Portanto, a ciência do número, enquanto considera o número, não especula naquilo, a não ser conforme respeito pelo qual the ocorre existir na natureza porque se vê que o princípio de sua consideração, conforme o que ele é na estimação, seja do mesmo modo que a avaliação seja aceita a partir das disposições naturais que julguem ser associados e desassociados, unidos e divididos. Donde a ciência sobre o número não é especulação sobre a essência do número, nem dos acidentes do número enquanto é número em absoluto, mas dos seus acidentes enquanto se tornam receptíveis daquilo que assinalamos; e então, é humano material ou estimável apoiado à matéria. De fato, a pesquisa sobre a essência do número e sobre aquilo que lhe ocorre conforme o que não depende da matéria, nem é apoiado nela, está nesta ciência.

Avicena observa que a ciência do número não pode ser considerada uma ciência metafísica, pois esta não tem o número como objeto formal de pesquisa, visto que os números se encontram tanto separados da matéria, como se encontram nas coisas naturais;

\footnotetext{
${ }^{86} \mathrm{Idem}, 26-27$.
} 
e mesmo separados, não podem ser apreendidos pelo intelecto sem uma relação com as coisas (numericamente) existentes. E acrescenta que a especulação do número em si mesmo, em sua situação de totalmente separado da matéria, ou de tudo que seja natural, o que nele se especula não está relacionado com as proporções numéricas, e assim pelo fato de ser um existente. Nesse caso, não se admite que esteja relacionado com proporções numéricas ou coisas naturais.

No caso das ciências matemáticas, ao contrário, o estudo do número se dá na medida em que ele existe nas coisas naturais, ou seja, está relacionado com as disposições quantitativas "associados ou desassociados, unidos e divididos" das coisas naturais. Sua intenção não se volta à especulação do número em si mesmo, visto de modo absoluto, segundo o que ele é (sua essência) e seus respectivos acidentes - a não ser os acidentes numéricos relativos às coisas naturais e materiais -, pois esse tipo de investigação é próprio da ciência metafísica.

Em suma, o filósofo procura qual a melhor definição para esta ciência, apresentando duas denominações que lhe parece mais convenientes: "Sobre aquilo que está após a natureza", que precisamos por Metafísica, e Ciência Divina ou Teologia, e aqui num sentido filosófico racional e não no de uma doutrina religiosa. Na primeira, o autor precisa o que é sob o ponto de vista do cientista, pois consta daquilo que se percebe após as coisas naturais ou sensíveis, ou mesmo a partir delas como sua causa ou princípio, mas que sob o ponto de vista das realidades em si, trata-se do que está aquém das coisas naturais, os seus fundamentos, e aqui denominaríamos de "Profísica".

Esta ciência é chamada de Ciência Divina ou Teologia, pois, segundo Avicena, se refere ao que de mais sublime esta ciência estuda, o divino, ou os Intelectos separados, como veremos mais adiante. Sendo assim, pode-se dizer que, na concepção do filósofo, esta seria uma denominação metonímica, ou seja, a parte (mais excelente) pelo todo (que se especula).

\section{III.5. Recapitulação geral}

As intenções de Avicena no terceiro capítulo desta obra em questão consistiu em indicar a utilidade da Metafísica, justificar sua posição como última ciência a ser estudada na ordem das ciências filosóficas e definir o seu nome.

Para esclarecer a utilidade da Metafísica, o filósofo parte da noção mesma de utilidade. Esta consiste na intenção que afasta do mal em vista do bem. Aplicando isso às ciências, a utilidade das ciências em geral consiste no aperfeiçoamento do espírito 
mediante a aquisição do conhecimento pela sua operação cognitiva. Ao conhecer, o espírito adquire a perfeição da faculdade intelectiva, realizando-se e atingindo a satisfação que é a felicidade ou beatitude.

Ora, segundo Avicena, as ciências são interligadas umas às outras de acordo com o seu campo de pesquisa, seguindo uma certa interligação orgânica. Sendo assim, a utilidade de uma ciência se faz de dois modos:

a) De modo absoluto, quando uma ciência verifica a certeza dos princípios que fundamentam a pesquisa de outra.

b) De modo próprio, quando uma ciência procura a excelência sem incorrer em transformar-se em outra ciência em função de seu objeto de estudo.

A Metafísica atua das duas maneiras, verifica os princípios das demais ciências, garantindo-lhes a veracidade de seus fundamentos, e busca maior excelência ao especular o primeiro princípio ou princípio absoluto. Desse modo, ela não constitui uma ciência de serviço subalterno, porquanto é superior às demais por nela encontrar as bases de sua investigação.

A partir disso, coloca-se a questão em que ordem ela deve ser estudada. Ora, como é evidente pela própria organização da obra, a Metafísica é estudada após as demais. Entretanto, o autor vê-se na necessidade de justificar a razão pela qual se deve estudá-la por último, visto estar nela os fundamentos da demais ciências filosóficas. E ainda mais, levanta-se a seguinte objeção que propomos numa construção silogística: os princípios das ciências naturais e matemáticas são examinados e verificados pelas ciências intelectuais; ora, são por meio desses princípios que as ciências naturais e matemáticas examinam suas questões; logo, as questões de ambas se converteriam em princípios das ciências intelectuais, o que redundaria num círculo vicioso.

O filósofo esclarece afirmando que um princípio de uma ciência não é necessariamente um princípio absoluto, podendo ser investigado por outras ciências, e nem necessariamente deve ser assumido desse modo por questões de outras ciências, algumas das quais só admitem como princípio aquilo que é reconhecido como verdadeiro, de modo que não sejam, de fato, princípios, mas ideias das coisas existentes apreendidas a partir da percepção das realidades em si pelos sentidos anímicos.

Recorda, ainda, que pelos limites da faculdade intelectiva do espírito, não é possível atingir diretamente o conhecimento das coisas inteligíveis ou dos princípios absolutos em si mesmos. Porquanto o nosso conhecimento deve partir dos sensíveis e, por indução, até o conhecimento de suas causas remotas. É partindo dessa ideia que 
Avicena inicia a discussão do nome desta ciência, começando pelo de Metafísica, que, na obra, ele expõe a tradução por extenso da expressão grega usada por Aristóteles: ciência d'Aquilo que está após a natureza.

É chamada assim pelo fato de percebermos os fundamentos das coisas existentes a partir da percepção das próprias coisas existentes. Portanto, a denominação parte do ponto de vista do próprio sujeito cognoscente. E como uma ciência pode receber o nome daquilo que lhe é mais excelente, a Metafísica, segundo o filósofo, é chamada de Ciência Divina (Teologia), pois o divino é o que há de mais excelente do que é especulado por esta ciência e consiste no primeiro princípio.

Levantando a questão de que também as ciências matemáticas são ciências após a natureza, o autor distingue entre aquilo que as ciências intelectuais especulam, realidades totalmente separadas das coisas naturais, enquanto que as matemáticas estão relacionadas de algum modo às quantidades e extensão dos corpos. Por outro lado, a denominação Ciência Divina será mais conveniente, pois esta não corre o risco de relacionar com as coisas naturais, referindo-se claramente às supranaturais.

Em todo caso, Avicena se restringe a estas duas denominações, nada sugerindo às divisões que citara anteriormente. Aqui ele deixa um espaço aberto a ulteriores pesquisas dos que, porventura, queiram dar continuidade à sua reflexão.

Com isso, findamos o comentário dos três primeiros capítulos de sua obra na qual o autor estabelece a Metafísica ou Ciência Divina como ciência filosófica. 


\section{Conclusão}

Quando eram realizadas as traduções dos corpora greco-arábico-judaicos ao latim, na cidade de Toledo, no século XII, que logo fermentariam as universidades europeias (séc. XIII) com o pensamento predominantemente aristotélico, a filosofia latina havia atingido o seu pleno florescimento sob a férula do platonismo, especificamente da obra platônica do Timaeus, que se convertera na fonte de especulação teológica e cosmológica $^{87}$, expressando-se não somente em tratados de especulação filosóficocientífica, mas também na arquitetura e nas artes literárias, como, por exemplo, as catedrais góticas e grandes poemas como o Roman de la Rose, uma verdadeira "enciclopédia" da civilização medieval em versos.

Um importante símbolo intelectual dessa época foi a escola vitorina, cujo centro era a Abadia de São Vítor, em Paris, e seu principal representante, Mestre Hugo de Paris (ou de São Vítor), cujas obras são uma síntese do pensamento medieval anterior a entrada do pensamento árabo-judaico. Em sua clássica obra Didascalicon de studio legende, obra didática dirigida aos estudantes, Mestre Hugo propõe uma classificação das ciências filosóficas que sintetiza a concepção euro-latino-ocidental da Filosofia como conjunto do saber, acrescendo sua própria contribuição que influenciará os pósteros, como Boaventura de Albano (séc. XIII). Eis sua classificação no quadro a seguir ${ }^{88}$ :

\begin{tabular}{|c|c|c|c|c|c|}
\hline \multicolumn{6}{|c|}{ Classificação das Ciências Filosóficas segundo Mestre Hugo de Paris } \\
\hline \multirow{11}{*}{ Filosofia } & \multirow{4}{*}{ Teórica } & \multicolumn{4}{|c|}{ Teologia } \\
\hline & & \multirow[t]{2}{*}{ Matemática } & \multicolumn{2}{|c|}{ Aritimética } & Música \\
\hline & & & \multicolumn{2}{|c|}{ Geometria } & Astronomia \\
\hline & & \multicolumn{4}{|c|}{ Física } \\
\hline & Prática & Ética & \multicolumn{2}{|c|}{ Econômica } & Política \\
\hline & \multirow[t]{2}{*}{ Mecânica } & Lanifício & Teatro & Caça & Medicina \\
\hline & & Agricultura & \multicolumn{2}{|c|}{ Navegação } & Armamento \\
\hline & \multirow{4}{*}{ Lógica } & \multicolumn{4}{|c|}{ Gramática } \\
\hline & & \multirow{3}{*}{ Raciocínio } & \multicolumn{3}{|c|}{ Demonstração } \\
\hline & & & Prov & Dialé & Retórica \\
\hline & & & \multicolumn{3}{|c|}{ Sofística } \\
\hline
\end{tabular}

\footnotetext{
${ }^{87}$ Cumpre notar que aqui o termo "teológica" tem o sentido de "metafísica", distinguindo-se de "doutrina sagrada" que era denominada sacra pagina.

${ }^{88}$ Cf. Esta tabela foi feita por nós a partir das informações colhidas em HUGO DE SÃO VÍTOR, Didascálicon da arte de ler. Petrópolis: Ed. Vozes, 2001, p. 17 (Introdução de Antonio Marchionni).
} 
Ao introduzir as ciências mecânicas na tradicional divisão tripartite do saber filosófico (teóricas, práticas e lógicas), Mestre Hugo adota o princípio aristotélico pelo qual é necessário haver tantas partes da filosofia quantas são as diversidades dos existentes; entretanto, o labor humano ainda não havia sido incluído na reflexão filosófica. Sendo assim, ao conhecer, ao agir e ao argumentar, ele acrescenta o fazer às ciências filosóficas.

A constituição das classificações das ciências filosóficas se deu na Antiguidade imperial, fundando-se no modo como se realizava a educação dos adolescentes, modo que persistiu no medievo bizantino e latino, consagrado com as expressões trivium e quadrivium. A primeira consistia numa espécie de ensino primário ou fundamental e era uma introdução às artes literárias e argumentativas (gramática, retórica e dialética); a segunda, consistia no ensino médio, sendo uma introdução ao conhecimento científico ou matemático (geometria, aritmética, música e astronomia); a partir disso, o estudante estava preparado para seguir o ensino superior, que consistia na filosofia teológica, na medicina ou no direito.

A partir disso, e com a introdução da cosmologia platônica que fundava as ciências físicas ou naturais, completou-se o ciclo ternário das ciências filosóficas: teóricas, práticas e lógicas; teóricas: superior (teológica), média (matemática) e inferior (física); práticas: individual (ética), privada (econômica), pública (política); lógicas: gramática, retórica e dialética. ${ }^{89}$

No século XII, a Lógica Antiga tem seu pleno desenvolvimento, principalmente com Abelardo, antes da introdução completa do Organon aristotélico pelos árabes; e com Mestre Hugo, são introduzidas as sete artes mecânicas. ${ }^{90}$ É neste mesmo século que se colocam os fundamentos da instituição universitária que florescerá no século XIII.

O cume da Filosofia se encontra na Teologia (no sentido já exposto), que Mestre Hugo define em sua obra da seguinte maneira:

Segundo Boécio, o intelectível é aquilo que, permanecendo sempre um e o mesmo por si em sua própria divindade, nunca é alcançado por algum dos sentidos, mas somente pela mente e pelo intelecto. Esta atividade comporta indagação sobre a

\footnotetext{
${ }^{89}$ A organização ternária das ciências tinha também valor simbólico: o número três era considerado o número da perfeição e da permanência, pois, era o primeiro número ímpar composto, não podendo ser dividido por um número inteiro; a figura geométrica do triângulo em qualquer posição sempre permanece em pé; e era o número de Deus, pois, no cristianismo Deus é uni-trindade. Sendo assim, possuía o sentido de abarcar o conhecimento de tudo que levava à perfeição do saber.

90 Notar também a simbologia do número sete.
} 
especulação de Deus, sobre a imortalidade do espírito e sobre a consideração da verdadeira filosofia, e os gregos denominam isso theologia.

A teologia é assim chamada porque é como um discurso sobre Deus, pois theos significa Deus e logos significa discurso ou razão. "Faz-se teologia, portanto, quando pomos em discussão, com aplicação profundíssima, algum aspecto da inefável natureza de Deus ou das criaturas espirituais". (Didasc. II, 2)

Essa definição corrente de Teologia é fundada tanto em Boécio, como em Isidoro de Sevilha e Cassiodoro, estes últimos não nomeadamente, mas o trecho que colocamos em aspas é uma citação das Etymologiae (II,24,13) e das Institutiones (II,3,6) dos respectivos. Aqui nada se fala da doutrina revelada ou dos estudos de Sagrada Escritura. Para os medievais, o grande mestre em Teologia filosófica, ou melhor, em Filosofia teológica, era Platão, mas também os neoplatônicos transmitidos pelos bizantinos.

Como se pode notar, a ciência teológica, no sentido apresentado, trata das realidades espirituais e divinas não perceptíveis aos sentidos psíquicos e que, segundo a linguagem boeciana, são realidades "intelectíveis". Sendo assim, ela ocupa, na filosofia medieval latina, a função da ciência metafísica e equivale ao que Avicena chamou primeiramente de Ciência Divina..$^{91}$

Entretanto, a introdução do pensamento árabo-aristotélico, especificamente da Metaphysica Avicennae, como ficou conhecido mais tarde o Liber de Philosophia Prima sive Scientia Divina em analogia à Metaphysica Aristotelis, ofereceu à intelectualidade europeia do século XIII novas ideias para a reflexão filosófico-teológica. Grandes nomes como Guilherme de Alvérnia, Alberto de Colônia, Alexandre de Hale, Rogério Bacon, Boaventura de Albano, Tomás de Aquino, Duns Scott, entre outros, souberam fazer uso desse patrimônio em diferentes graus e sob aspectos diversificados, acrescentando essas novas ideias à herança antiga e criando novas sínteses.

Por essa razão, o estudo da Metafísica de Avicena é de grande relevância para a compreensão do desenvolvimento das ciências filosóficas e metafísicas na tradição da filosofia ocidental, desde a sua entrada no século XIII, nas Universidades de Paris e de Oxford, até o século XX, com grandes nomes como Martin Heideigger e Edith Stein. Para se compreender como Avicena estabelece esta ciência, é fundamental o conhecimento da estrutura orgânica da sua classificação das ciências que se faz a partir da árvore de Porfírio, ou seja, da distinção das ciências a partir de seus objetos e de suas relações

\footnotetext{
${ }^{91}$ Em árabe علم الثي ('ilm ilāhiy).
} 
segundo a classificação em gênero e espécie. Entretanto, a própria classificação aviceniana das ciências não é uma questão tão simples.

Os estudos que se fazem sobre o assunto geralmente apresentam a classificação aviceniana das ciências, em parte, sob o ponto de vista didático, seguindo não somente a ordenação em gênero e espécie dos objetos formais das diversas ciências, como também a ordem em que devem ser estudadas. Tradicionalmente a classificação aviceniana das ciências se faz segundo o seguinte esquema: ${ }^{92}$

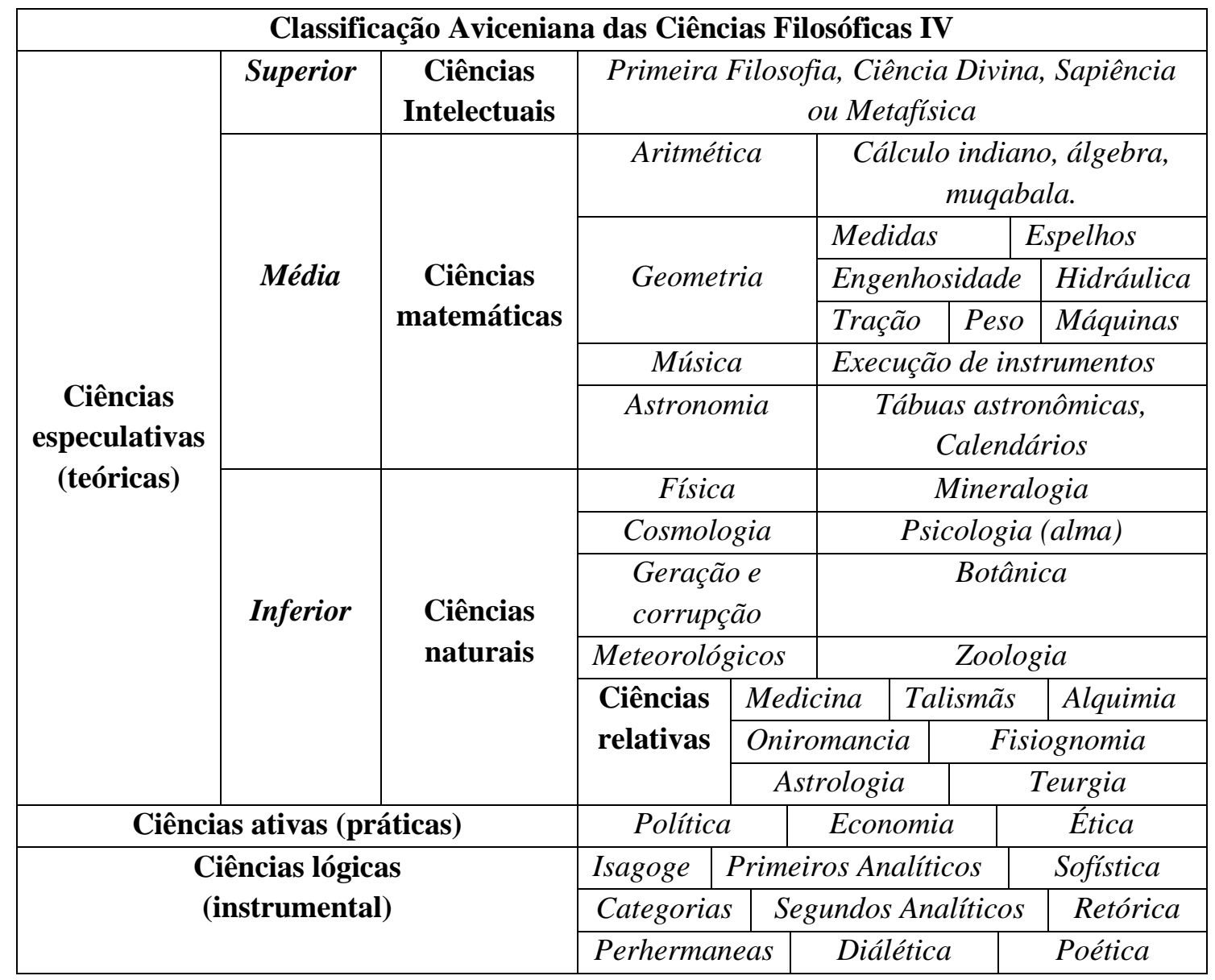

Numa análise mais detalhada desta classificação, podemos perceber não somente a ordem didática de ensino, mas também a construção a partir do ponto de vista do sujeito cognoscente: a) ciência do raciocínio; b) ciência do agir; c) ciência do conhecer. As ciências do conhecer, por sua vez, se realizam em três fases: a) a percepção das coisas sensíveis e naturais; b) a abstração dos aspectos numéricos ou quantitativos das coisas

\footnotetext{
${ }^{92}$ Cf. Esta tabela foi feita por nós a partir das informações colhidas em ATTIE, Falsafa, op. cit., p. 238; Inteligência e Metafisica em Ibn Siña (Avicena). São Paulo: Ed. do Autor, 2012, p. 49.59-60. Procuramos conservar o tanto quanto possível a nomenclatura latina. Além da, Al-Šifă', outra fonte para a classificação filosófica de Avicena é a Epístola sobre as divisões das ciências intelectuais, de Ibn Sīna.
} 
existentes; c) a intelecção das coisas existentes em si mesmas, em sua realidade essencial ou substancial e não acidental ou aspectual. A distinção entre ciências teóricas superior, média e inferior está relacionada tanto com a concepção psicológica, como cosmológica de Avicena. As inferiores estão relacionadas aos sentidos inferiores e às coisas existentes sublunares, enquanto que as superiores estão relacionadas com a intelecção e com a parte superior do mundo das esferas, realidades pertencentes ao domínio do divino. A média, uma abstração quântica, está entre as duas realidades cosmológicas e se dirige, no caso da Astronomia, às esferas supralunares.

Para ficar claro o que foi dito, cumpre esclarecer essas noções cosmológicas. A concepção cosmológica de Avicena se funda no sistema de Al-Fārābī (872-950) que, por sua vez, alia o princípio de emanação de Plotino ao sistema geocêntrico de Ptolomeu. Segundo Al-Fārābī, o Primeiro Existente ama-se e alegra-se em si mesmo de modo tão perfeito que o próprio ato de amar e o objeto de amor coincidem com o próprio amante. ${ }^{93}$ A partir do Primeiro Existente, emana de sua própria substância, sem necessidade ou alteração alguma, no interior e não fora de si, à Segunda Inteligência, de natureza incorpórea e de gradação inferior ao Primeiro Existente, e que se identifica com o Primeiro Céu ou Empíreo. Aquela, por sua vez, ao contemplar o Primeiro Existente e a si mesma, produz uma segunda emanação da Terceira Inteligência correspondente à esfera das estrelas fixas e assim por diante; cada Inteligência, ao contemplar o Primeiro Existente ou Primeira Inteligência e a si mesma, produz uma nova emanação de uma Inteligência em grau inferior a si que corresponde uma esfera onde está fixado um corpo celeste, totalizando o número de dez Inteligências, contando da Primeira até a Lua, como se segue na disposição abaixo ${ }^{94}$ :

a) Segunda Inteligência: Primeiro Céu ou Empíreo;

b) Terceira Inteligência: esfera das estrelas fixas;

c) Quarta Inteligência: esfera de Saturno;

d) Quinta Inteligência: esfera de Júpiter;

e) Sexta Inteligência: esfera de Marte;

f) Sétima Inteligência: esfera do Sol;

g) Oitava Inteligência: esfera de Vênus;

\footnotetext{
93 Curiosamente essa concepção é praticamente a mesma de Agostinho de Hipona em seu tratado De Trinitate. Contudo, por circunstâncias óbvias, o filósofo muçulmano não dá o passo agostiniano de afirmar que Deus é Trindade.

${ }^{94}$ Cf. ATTIE, Falsafa, op. cit., p. 209-215; DE LIBERA, A Filosofia Medieval, São Paulo: Ed. Loyola, 2011, p. 112-116.
} 
h) Nona Inteligência: esfera de Mercúrio;

i) Décima Inteligência: esfera da Lua;

j) Décima Primeira Inteligência: mundo sublunar.

Cada uma dessas Inteligências está relacionada com uma esfera que é dotada de uma alma como princípio de movimento que move os respectivos corpos celestes em sentido circular (as próprias esferas estão em constante movimento produzindo, segundo essa opinião, sons musicais sublimes e sutis), tendo a Terra como centro, segundo o sistema ptolomaico. A décima Inteligência esgota o processo de emanação e produz a matéria informe a partir da qual se realiza o processo inverso, passando do menos perfeito ao mais perfeito numa gradação de existentes que parte dos elementos primordiais (água, terra, ar e fogo), dos quais são compostos os existentes corruptíveis: os minerais, os vegetais, os animais irracionais (sensitivos) e o homem (animal racional), composto de todos os demais elementos anteriores e de uma inteligência inferior, mas próxima, à da esfera lunar, constituindo-o no supremo existente do mundo sublunar.

Essa inversão da gradação dos existentes sublunares descritas por Al-Fārābī, em que a última emanação das Inteligências separadas (da matéria) se degradam para a matéria-prima a partir da qual se torna complexa pela "evolução" dos existentes, segue o princípio de Plotino do retorno das coisas ao Primeiro Existente - o princípio que Scott Eriúgena chamaria em latim de egressio regressio ("saída-retorno") - no qual o homem seria o limite do retorno no mundo sublunar.

Nesse contexto, o homem aparece como um microcosmos, uma síntese de todos os demais existentes, quer sublunares, quer os inteligíveis. Sendo assim, o homem (masculino ou feminino) é dotado de todas as faculdades relativas aos demais existentes: a faculdade de nutrição (e geração), a sensibilidade ou percepção sensível, o apetite, a imaginativa e a intelecção. $O$ homem possui ainda três níveis de apreensão do conhecimento: a percepção sensível, a imaginativa e a racional.

Aplicando essa concepção cosmológico-antropológica que, grosso modo, se fundava Avicena, ao conhecimento científico do homem, podemos compreender com mais clareza a classificação das ciências filosóficas, sobretudo no que diz respeito às ciências intelectuais ou metafísicas, como apresentadas nesta última tabela. Aprofundemos a questão.

A estrutura da tabela acima exposta possui uma relação tanto com o sistema cosmológico, como o do conhecimento humano. Do mesmo modo que, partindo dos existentes sublunares, há uma elevação às esferas supralunares até atingir o primeiro céu 
e, em seguida, o Primeiro Existente. O mesmo ocorre na gradação das faculdades cognitivas do homem, que se elevam do sensível ao intelectivo e, consequentemente, a ordem da tabela segue de modo ascendente, de baixo para cima, em correspondência à estas estruturas.

Sendo assim, na ordem didática, a base da tabela é ocupada pelas ciências lógicas, aquelas que educam o raciocínio como um instrumental para o cultivo das demais ciências filosóficas. Avicena se funda nas obras do Organon aristotélico, fundante da lógica peripatética. Seguem-se as ciências práticas, relacionadas ao agir humano, que estabelece os princípios da atividade humana no contexto de sua vida "terrena", divididas em três ciências: a Ética, que rege as ações individuais; a Economia, que rege a administração privada ou familiar; e a Política, que rege a administração social, civil ou pública.

Acima vem as ciências teóricas ou contemplativas, as ciências do conhecimento especulativo, começando pelas ciências "inferiores", ou seja, as ciências naturais, as que se referem aos existentes sublunares, na seguinte ordem, seguindo também a tradição peripatética: Física, que trata das causas em seus efeitos e dos efeitos a partir das causas; a Geração e Corrupção, que trata dos corpos sublunares em sua origem e destruição, ou o seu movimento; a Mineralogia, a Botânica, a Zoologia e a Psicologia, que trata respectivamente dos minerais, dos vegetais, dos animais irracionais e do princípio vital, cujo cume é a alma humana; seguem-se a Cosmologia e a Meteorologia que tratam dos fenômenos cósmicos. A estas dependem outras ciências relativas, como, por exemplo, a Medicina, entre outras.

Acima são colocadas as ciências médias ou matemáticas, que tratam das quantidades abstratas e são divididas em ciências das quantidades contínuas (grandeza) e das descontínuas (pluralidade). As primeiras dividem-se em duas: a medição das quantidades imóveis, como a Terra (Geometria), e a medição das quantidades móveis, como as esferas celestes (Astronomia). As segundas são divididas também em duas: as quantidades relativas a alguma coisa (Música) e as quantidades numéricas, que são tais por si mesmas (Aritmética). Embora tenham um grau de abstração, essas ciências dependem das realidades corpóreas ou materiais. A própria noção de número se deve à contagem de existentes corpóreos. Essas quatro ciências são matrizes para tantas outras conforme exposta na tabela acima. ${ }^{95}$

\footnotetext{
${ }^{95}$ Cf. HUGO DE SÃO VITOR, op. cit., p. 95-103; ROONEY, A. A História da Matemática. São Paulo: M.Books, 2012, p. 13-37. Observamos na tabela que, além das ciências aprendidas dos gregos mediante os romano-bizantinos e os sírios, há conhecimentos que os árabes adquiriram dos indianos e dos chineses,
} 
Por fim, no cume da tabela, encontram-se as ciências superiores ou intelectuais, cuja existência é aquela que Avicena procura demonstrar e estabelecer nos primeiros capítulos da obra estudada na presente pesquisa. É indicada como ciência superior por se tratar de realidades superiores tanto na ordem do existir, como por estar espacialmente na posição superna e também por ser conhecida pelo homem por sua faculdade superior, a razão. É chamada também de "ciências intelectuais" (na forma plural) por tratar das inteligências separadas (da matéria) e por ser fruto da intelecção do homem.

Avicena propõe inicialmente algumas qualificações/denominações para esta ciência: Primeira Filosofia, Ciência Divina, Sapiência. A primeira expressão (Primeira Filosofia) refere-se ao conhecimento dos primeiros existentes (as Inteligências) enquanto são causas ou fundamentos de tudo o mais. A partir disso, podemos perceber (na obra de Avicena) três divisões da Primeira Filosofia: a ciência do existente enquanto tal (“Ontologia”), ou seja, em sua própria substância (o que a coisa é independente de seus acidentes contingentes); a ciência das primeiras causas (ou das últimas, o que vem a dar no mesmo dependendo do ponto de vista) de todos os demais existentes ("Etiologia"); a ciência dos primeiros princípios (“Arquilogia”) referente aos princípios primordiais daquilo que é investigado nas demais ciências filosóficas.

A segunda expressão, Ciência Divina, refere-se ao mais excelente contemplado por esta ciência: o Primeiro Existente, ou a Primeira Inteligência, identificado com o Divino e, portanto, trata-se da ciência do divino (Teologia), porém, sob o ponto de vista da especulação filosófica ou intelectual, distinguindo-se da ciência das coisas فاسفة divinamente reveladas que, no caso do islã, corresponde ao / kalām $^{96}$, distinto da I falsafa, a filosofia propriamente dita, e no caso do cristianismo latino a sacra página (doutrina sagrada).

Por fim, a Sapiência, ou seja, o conhecimento perfeito por tratar-se do conhecimento da Primeira Inteligência, que é a suprema Sapiência ou Sabedoria, e, portanto, Onisciente, a partir da qual se pode conhecer mais perfeitamente tudo o mais, pois parte do Princípio Absoluto de todas as coisas.

Avicena propõe ainda uma quarta denominação, que consiste na expressão "sobre aquilo que está após a natureza”, que reduzimos aqui ao termo equivalente Metafísica,

provavelmente via persas, o que veio a enriquecer o leque de conhecimento científico no mundo áraboislâmico, em parte retransmitido aos europeus.

${ }^{96}$ Literalmente significa "discurso", "linguagem", "palavra" e consistiu num método de interpretação ou exegese do texto sagrado seguindo o modelo cristão da escola teológica antioquena, cuja base era o aristotelismo, oposto ao platonismo da escola alexandrina. 
como será posteriormente usual. Embora trate-se do conhecimento dos fundamentos de todas as coisas e, portanto, daquilo que está no início e vem antes das coisas naturais (sendo, então, "sobre aquilo que existe antes da natureza"), Avicena parte do ponto de vista da nossa percepção e, portanto, daquilo que podemos conhecer depois de conhecer o que é mais próximo ao nosso conhecimento sensível, ou das coisas sensíveis. Não podemos conhecer primeiro as causas e depois os efeitos correspondentes, mas a partir das coisas em efeito, conhecer por via indutiva as suas causas. Portanto, é chamada Metafísica por se referir às coisas que transcendem às naturais, ou os transcendentais.

A partir disso, dispomos uma outra tabela, comentando em seguida:

\begin{tabular}{|c|c|c|c|c|c|c|}
\hline \multicolumn{7}{|c|}{ Classificação Aviceniana das Ciências Filosóficas V } \\
\hline \multirow{17}{*}{$\begin{array}{c}\text { Ciências } \\
\text { especulativas } \\
\text { (teóricas) }\end{array}$} & \multirow[b]{2}{*}{ Superior } & \multirow{2}{*}{$\begin{array}{c}\text { Ciências } \\
\text { Intelectuais }\end{array}$} & \multirow[t]{2}{*}{ Metafísica } & \multicolumn{2}{|c|}{ Teologia } & Etiologia \\
\hline & & & & \multicolumn{2}{|c|}{ Arquilogia } & Ontologia \\
\hline & \multirow{3}{*}{ Racional } & \multirow{3}{*}{$\begin{array}{l}\text { Ciências } \\
\text { Lógicas }\end{array}$} & Isagoge & \multicolumn{2}{|c|}{ Primeiros Analíticos } & Sofística \\
\hline & & & Categorias & \multicolumn{2}{|c|}{ Segundos Analíticos } & Retórica \\
\hline & & & Perhermaneas & \multicolumn{2}{|c|}{ Dialélica } & Poética \\
\hline & \multirow{6}{*}{ Média } & \multirow{6}{*}{$\begin{array}{c}\text { Ciências } \\
\text { matemáticas }\end{array}$} & Aritmética & \multicolumn{3}{|c|}{$\begin{array}{c}\text { Cálculo indiano, álgebra, } \\
\text { muqabala. }\end{array}$} \\
\hline & & & \multirow{3}{*}{ Geometria } & \multicolumn{2}{|c|}{\begin{tabular}{|l|l} 
Medidas & Espelhos \\
\end{tabular}} & \\
\hline & & & & \multicolumn{2}{|c|}{ Engenhosidade } & $\begin{array}{l}\text { Traçao } \\
\text { Hidráulica }\end{array}$ \\
\hline & & & & Máqui & & Peso \\
\hline & & & Música & \multicolumn{3}{|c|}{ Execução de instrumentos } \\
\hline & & & Astronomia & \multicolumn{3}{|c|}{$\begin{array}{c}\text { Tábuas astronômicas e } \\
\text { Calendários }\end{array}$} \\
\hline & \multirow{6}{*}{ Inferior } & \multirow{6}{*}{$\begin{array}{l}\text { Ciências } \\
\text { Naturais }\end{array}$} & Física & \multicolumn{2}{|c|}{ Cosmologia } & Mineralogia \\
\hline & & & \multicolumn{2}{|c|}{ Geração e corrupção } & Met & orológicos \\
\hline & & & Botânica & \multicolumn{2}{|c|}{ Zoologia } & Psicologia \\
\hline & & & \multirow{3}{*}{$\begin{array}{l}\text { Ciências } \\
\text { relativas }\end{array}$} & Medicina & Talisn & \begin{tabular}{l|l}
$\tilde{a} s$ & Alquimia
\end{tabular} \\
\hline & & & & Onirome & ncia & Fisiognomia \\
\hline & & & & Astrolo & & Teurgia \\
\hline Ciênci & ativas (pr & ticas) & Política & Econ & mia & Ética \\
\hline
\end{tabular}

No decorrer de nossa pesquisa, percebemos que o filósofo propôs paralelamente uma outra classificação na qual desloca as ciências lógicas, consideradas então como ciências filosóficas e não como instrumental, para cima da média e abaixo das intelectuais, por um lado, e, por outro, descreve com maiores detalhes as intelectuais em partes ou subdivisões (como já indicado). Isso não anula a classificação anterior, mas oferece uma outra perspectiva que lhe pode ser, de certo modo, complementar.

Nesta nova classificação, não é levada em consideração a ordem didática, mas uma nova proposta de gradação das coisas especuladas pelas ciências filosóficas que vai 
do mais corpóreo ao totalmente imaterial. Consiste num conhecimento inteiramente subjetivo, isto é, sob o ponto de vista exclusivo de sujeito cognoscente.

Principia no conhecimento racional do modo reto do agir humano individual (Ética), privado ou familiar (Economia) e público ou social (Política). Segue-se o conhecimento especulativo das coisas naturais em seus acidentes, ou sob o aspecto de suas qualidades contingentes, de seu movimento ou repouso e de suas causas e efeitos; da gradação ascendente dos existentes, os minerais e os viventes (vegetais, sensíveis, racionais) e aquelas paralelas que se referem à saúde orgânica (Medicina) e outras ciências; as ciências da abstração quântica ou numérica ou matemáticas.

Acima se encontram as ciências das coisas imateriais. Avicena coloca, então, acima das matemáticas, as ciências lógicas (ou racionais) por estas tratarem não de coisas materiais, mas de conceitos ou de existentes conceptuais ou mentais (os chamados "entes de razão"). Seu conhecimento se faz não a partir de coisas extramentais, mas de ideias a partir das quais, por um processo discursivo (lógico) se chega a determinadas conclusões. Esse processo se dá exclusivamente no intelecto, sem elementos extrínsecos, a faculdade superior do homem que o distingue dos outros existentes sublunares e o aproxima às Inteligências cósmicas. Nesse ponto de vista, as ciências lógicas estão a um grau anterior às ciências intelectuais ou metafísicas, que já tratamos e não há necessidade de retomar.

Como já dito, esta outra classificação não anula a anterior, mas oferece uma outra perspectiva da conceptualização das ciências filosóficas. Sendo assim, temos uma visão geral de como Avicena concebe as ciências filosóficas e como ele estabelece e delimita a Metafísica neste conjunto. Abstraindo de nossas percepções refletidas em nosso discurso, podemos concluir que Avicena propõe dar preferencialmente a esta ciência duas denominações: Sobre aquilo que está após a natureza e Ciência Divina, que nós reduzimos a dois termos simples e equivalentes: Metafísica e Teologia, respectivamente. A primeira equivaleria à Primeira Filosofia, com todas as suas especificações já apontadas, e a segunda se restringiria à sua parte mais excelente, à especulação do Primeiro Existente, ou o Existente Divino, ou Absoluto, identificado pelo filósofo com o Deus corânico, embora não nos mesmos termos da doutrina dos intérpretes do livro sagrado.

A Metafísica de Avicena influenciou os autores euro-latinos em graus diversos com maior ou menor aceitação, sempre lido de modo crítico, originando diversas doutrinas filosóficas nas escolas espanholas, francesas, inglesas e alemãs durante o século XIII. Citemos particularmente três desses autores: Domingos Gonzáles, o tradutor, que 
estabeleceu o seu próprio pensamento pautado no de Avicena, lendo-o, entretanto, sobre um viés cristão-agostiniano; Alberto de Colônia, que o usou em abundância para comentar a obra homônima de Aristóteles; Tomás de Aquino, que tomou Avicena como fonte para a sua própria reflexão metafísica.

Por outro lado, houve aqueles que mantinham uma severa reserva ao pensamento do filósofo muçulmano e, se o tinham como referência ou adotassem elementos de suas teses, recusavam o seu sistema em sua generalidade ou construíam o seu próprio sistema de modo crítico ou mesmo em oposição ao de Avicena. É o caso, por exemplo, dos pensadores franciscanos Boaventura de Albano e Duns Scott.

Tomemos como exemplo a classificação das ciências de Boaventura, que usa elementos da classificação de Avicena, mas propõe uma concepção bem diferente da dele em seu sistema geral. Observemos a tabela a seguir ${ }^{97}$ :

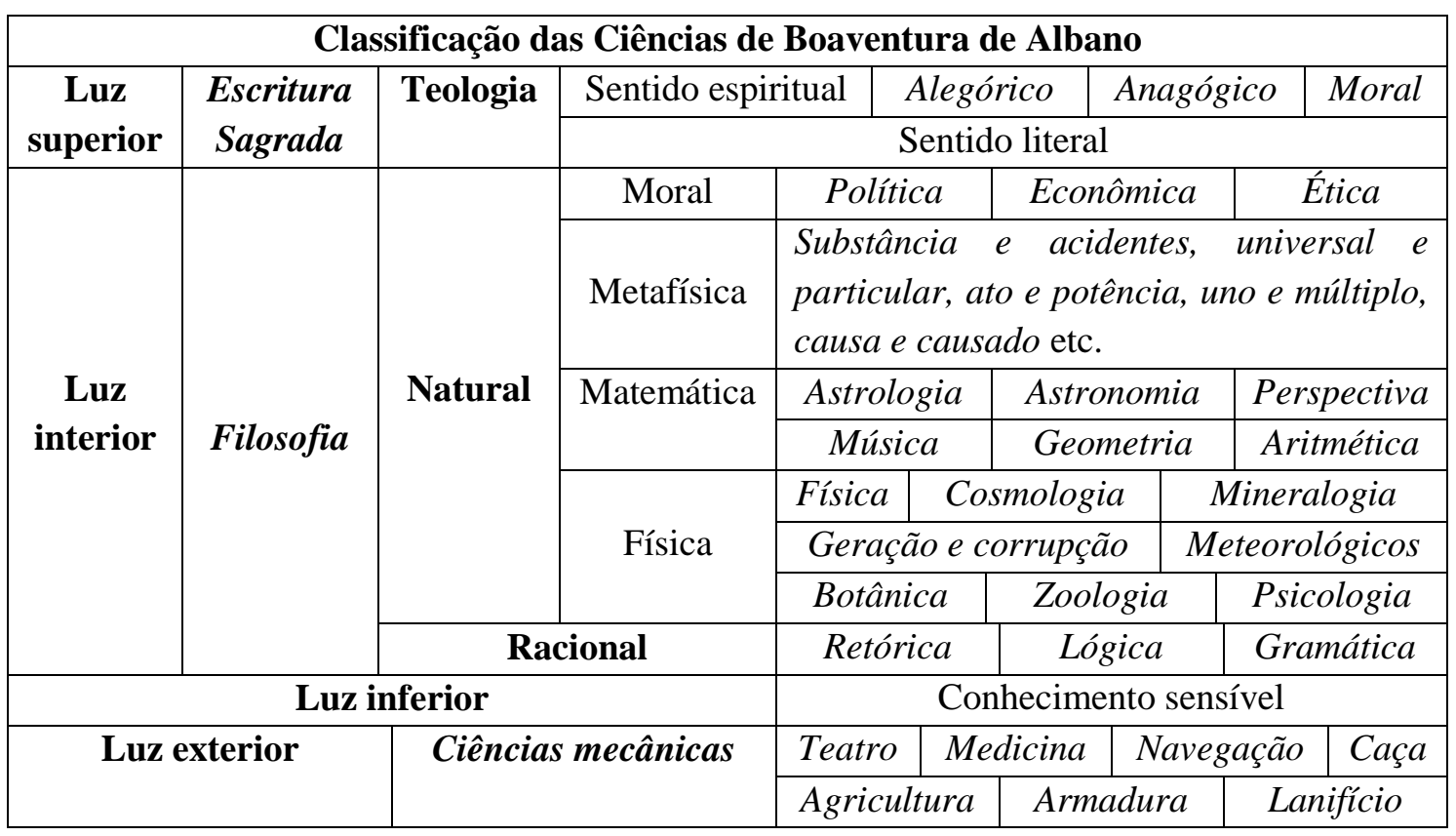

O que procede a tradição aristotélico-aviceniana é a concepção de Metafísica, as Ciências Físicas e a Lógica, embora esta não esteja especificada na tabela. Também o conteúdo da Matemática é equivalente ao transmitido por Avicena em grande medida. Boaventura acrescenta as Ciências Mecânicas, seguindo Hugo de São Vítor. Elementos aristotélico-avicenianos se encontram também nas Ciências Morais. Entretanto, o sistema é construído dentro da teoria da iluminação de Agostinho de Hipona.

97 Cf. Esta tabela foi feita por nós a partir das informações colhidas em BOAVENTURA. Escritos Filosófico-Teológicos. Porto Alegre: Edipucrs, 1999, p. 57. 
Segundo a analogia agostiniana da "luz do conhecimento", Boaventura descreve quatro modalidades gradativas de iluminação do conhecimento que, em parte, também é inspirada, mas não dependente, de Avicena:

a) A luz exterior, que consiste no conhecimento das coisas exteriores produzidas pelo engenho humano e se referem às Ciências Mecânicas propostas por Hugo de São Vítor;

b) A luz inferior, que se refere ao conhecimento sensível e das coisas sensíveis; em outras palavras, a percepção ou conhecimento sensorial;

c) A luz interior, que trata propriamente das ciências filosóficas, divididas por Boaventura em dois grupos: Racional e Natural; as Ciências Racionais correspondem às ciências do trivium, enriquecidas com a totalidade da lógica aristotélico-aviceniana; as Ciências Naturais são as ciências Físicas, Matemáticas, Metafísicas e Morais, nesta ordem ascendente.

d) A luz superior, que é a Teologia cuja fonte é a Sagrada Escritura; esta possui, segundo a tradição patrística, dois sentidos, um literal ou histórico e outro espiritual; este, por sua vez, possui três modos: o alegórico, o anagógico e o moral.

Portanto, podemos afirmar que, segundo Boaventura, existem quatro modalidades de conhecimento: a) o conhecimento artificial (das coisas realizadas pelo homem); b) o conhecimento sensível (que nos vem pelos sentidos anímicos); c) o conhecimento intelectual (que se realiza em nosso intelecto); e o conhecimento teológico (que nos vem pela interpretação das sagradas escrituras).

Três observações comparativas com a classificação de Avicena:

a) a Matemática, a Metafísica e as Morais são classificadas juntamente com as Físicas como ciências naturais por Boaventura e, juntamente com as Racionais, formam a Filosofia propriamente dita; são, como um todo, consideradas um conhecimento natural do homem, e das coisas naturais, correspondentes às coisas criadas por Deus. A concepção cósmica é diferente, unindo a noção cristã de criação com a noção platônica de produção; e aqui se distinguem, por um lado, do conhecimento artificial, das coisas realizadas pelo homem, e do conhecimento sobrenatural ou revelado e, ainda, do conhecimento intuitivo da percepção sensível;

b) As ciências lógicas e afins são consideradas propriamente ciências filosóficas e não mero propedêuticos, embora não sejam colocadas abaixo da Metafísica. Por 
outro lado, as Ciências Morais são colocadas acima da Metafísica, consideradas as supremas ciências filosóficas. Em Boaventura, a Metafísica perde o seu status de supremacia.

c) A Teologia é distinguida da Metafísica e se torna a ciência do sagrado e, assim, a ciência suprema.

Em Boaventura, a Filosofia deixa de ser o conjunto das ciências, como fez Avicena de modo mais amplo que seus antecessores, e passa a significar somente um grupo intermediário das ciências em geral.

Um outro exemplo agora é a concepção de Teologia e Metafísica de Duns Scott. A partir de Boaventura, na escola franciscana se faz uma nítida distinção entre Metafísica e Teologia. Enquanto que a segunda se torna um conhecimento de Deus, ou das coisas divinas, à luz da fé, a Metafísica não se distingue plenamente das Ciências Físicas, pois não passa dos limites do meramente natural. Enquanto a primeira é um conhecimento natural, a segunda é um conhecimento sobrenatural, revelado. Duns Scott passa a compreender o campo de pesquisa da Metafísica, como as causas e os princípios, como pertencente à própria Física. ${ }^{98}$ A sua concepção de Metafísica restringe-se à ideia da ciência do existente como resultado de sua leitura tanto de Avicena como de Aristóteles.

Contudo, Duns Scott concebe o existente de modo unívoco, e não análogo, como até então se fazia, seguindo Agostinho e Dionísio, o Areopagita, e como fizeram seus contemporâneos Tomás de Aquino e Boaventura. “O existente se converte em objeto de um saber transcendental, neutro, indiferente e comum, e é anterior a toda consideração teológica"99.

Sendo assim, Duns Scott faz da Metafísica uma ciência do existente enquanto tal, uma "Ontologia", em que, afastando-se do necessitarismo filosófico ao afirmar a contingência dos existentes em vista da liberdade criadora de Deus, distingue os existentes finitos do Existente Infinito, e assim, pode-se falar de uma estrutura onto-teológica de Duns Scott, que vincula o existente contingente do existente necessário (termos avicenianos). Desse modo, a Metafísica não somente é a coroação da filosofia física, mas, ainda mais, é o ingresso na Teologia filosófica ou racional (ou natural), ou, melhor ainda,

\footnotetext{
${ }^{98}$ Cf. DUNS ESCOTO, J. Filosofía y Teología, Dios y el hombre. Madrid: B.A.C., 2011, p. XIV-XV, introdução de Merino, J. A.

${ }^{99}$ Idem, XX.
} 
na theiologia ( $\theta \varepsilon 10 \lambda$ oүía), isto é, na ciência do divino mais do que de um Deus pessoal, que pode, segundo Duns Scott, ser conhecido somente pela revelação. ${ }^{100}$

Como visto, Duns Scott estabelece um novo conceito de Metafísica, um tanto original, colocando as bases daquilo que viria ser conhecido no séc. XVII por Ontologia, mas que dependeu de sua leitura crítica da Metafísica de Avicena.

Aqui concluímos a nossa pesquisa referente aos três primeiros capítulos da obra do filósofo persa muçulmano Avicena (séc. XI), a partir de sua tradução latina de Domingos Gonzáles e Ibn David realizada em Toledo no séc. XII, intitulada Liber de Philosophia Prima sive Scientia Divina, que trata da constituição e do estabelecimento da Metafísica como ciência filosófica.

O objetivo desta pesquisa, como dito no último parágrafo da introdução, consistiu numa análise dos três citados capítulos demonstrando como, a partir da delimitação do objeto formal e explanação da denominação desta ciência, a autor estabelecia uma nova ciência filosófica. Isto foi realizado conforme a estrutura proposta: em três capítulos, correspondetes aos capítulos da obra estudada, acompanhando o raciocínio de Avicena. Sendo assim, temos por findada esta pesquisa.

${ }^{100}$ Cf. Duns Escoto, op. cit., p. XX. 


\section{Bibliografia}

AL-KINDÎ, A Filosofia Primeira (tradução, introdução e notas por Miguel Attie Filho). São Paulo: Attie Editora, 2014.

ALMEIDA, A. R. (coord.) Dicionário Latim-Português. Porto: Porto Editora, 2008.

ATTIE F ${ }^{o}$, M. Falsafa. A filosofia entre os árabes. São Paulo: Palas Athena, 2002.

Inteligência e Metafísica em Ibn Sina (Avicena). São Paulo: Attie Editora, 2011.

AVICENA (Ibn Sîna). Epître sur les parties des Sciences intellectuelles d'Abu 'Ali alHusayn ibn Sina. In: RASCHED, R. e JOLIVET, J. (org.). Etudes sur Avicenne. Paris: Les Belles Lettres, 1984, p. 143-151.

La Métaphysique du Shifa', Livres I à V. Introduction et notes par Georges C. Anawati. Paris: J. Vrim, 1978.

Liber de Anima seu Sextus de Naturalibus IV-V. "Avicenna Latinus", Edição crítica por S. Van Riet e Introdução por G. Verbek, Louvain/Leiden: E. Peeters/E. J. Brill, 1968.

Liber de Pholosophia Prima sive Scientia Divina I-IV. "Avicenna Latinus", Edição crítica por S. Van Riet e Introdução por G. Verbek, Louvain/Leiden: E. Peeters/E. J. Brill, 1980.

Liber de Pholosophia Prima sive Scientia Divina V-X. "Avicenna Latinus", Edição crítica por S. Van Riet e Introdução por G. Verbek, Louvain/Leiden: E. Peeters/E. J. Brill, 1980.

Liber de Pholosophia Prima sive Scientia Divina I-X. Léxique. "Avicenna Latinus", Edição crítica por S. Van Riet e Introdução por G. Verbek, Louvain/Leiden: E. Peeters/E. J. Brill, 1983.

Metafísica, la scienza dele cose divine dal libro dela Guarigione. Traduzione dall'arabo, note e apparati di Olga Lizzini. Milano: Bompiani, 2002.

The Metaphysic of the Healing. A parallel English-arabic text translated, introduced, and annotated by Michael E. Masmura, Brighan Young. Provo/Utah: University Press, 2005.

IBN SÎNA (AVICENA). Livro da alma (trad. do árabe e comentários de Miguel Attie Filho). São Paulo: Ed. Globo, 2011.

BAILLYA, Dictionnaire grec-français. Paris: Hachette, 1950.

BETTENCOURT, E. Curso de Filosofia. Rio de Janeiro: Escola "Mater Ecclesiae", 2001

BLAISE, A. Lexicon latinitatis Medii Aevi. Turnholti: Brepols, 1975.

BOAVENTURA. Escritos Filosófico-Teológicos. Porto Alegre: Edipucrs, 1999.

BOEHNER, Ph. E GILSON, E. História da Filosofia Cristã. Petrópolis: Ed. Vozes, 2000.

BRAGUE, R. Au Moyen du Moyen Âge Philosophies Médiévales em Chretienté, Judaïsme et Islam. Champs, 2006.

CARDILLAC, L. Toledo, séculos XII-XIII. Rio de Janeiro: Zahar, 1992. 
CEGALlA, D. P. Novíssima Gramática da Língua Portuguesa. São Paulo: Companhia Editora Nacional, 2008.

CHROUST, A. M. "The Definitions of Philosophy in the De Divisione Pholosophiae of Dominicus Gundissalinus. In: The New Scholastcism, 25, 1951, p. 253-281.

COMBA, J. Gramática Latina. São Paulo: Ed. Salesiana, 2004.

CRUZ HERNÁNDEZ, M. Filosofía hispano-musulmana, 2 vols.. Madrid: Asociación Española para el Progreso de la Ciencia (AEPC), 1957.

D’ALVERNY, M.-T. Avicenne en Occident. Paris: J. Vrin, 1993.

DE LIBERA, A. A Filosofia Medieval. São Paulo: Ed. Loyola, 2004.

Pensar na Idade Média. São Paulo: Ed. 34, 1999.

D’ONOFRIO, G. Storia del pensiero medievale. Roma: Città Nuova, 2013.

DUNS ESCOTO, J. Filosofía y Teología, Dios y el hombre. Madrid: B.A.C., 2011.

ECO, U. (dir.) Il Medioevo. Barbari, cristiani e musulmani. Milano: Encyclomedia, 2010.

ERNOUT, A.; MEILlET, A. Dictionnaire Étymologique de la Langue Latine, Histoiredes Mots. Klincksieck, 1979.

FINIANOS, Gh. De L'existence à la nécessaire existence chez Avicenne. Bordeaux: Presses Universitaires, 2007

FIODORA, A.; BRUNA, J. S. "Gundisalvus o Dominicus Gundisalvi? Algunas observaciones sobre un reciente articulo de Adeline Rucquoi. In: Estudios Eclesiásticos, 76, 2001, p. 467-473.

FREIRE, A. Gramatica Latina. Braga: Publicações da Faculdade de Filosofia, 1987.

GILSON, E. A Filosofia na Idade Média. São Paulo: Martins Fontes, 2013.

GIORDANI, M. C. História do Mundo Árabe Medieval. Petrópolis: Ed. Vozes, 2001.

GOICHON, A. M. La philosophie d'Avicenne e son influence en Europe médievale. Paris: Lib. d'Amérique et d'Orient, 1940.

GREGORIM, C. O. Português. Gramática Prática. São Paulo: Melhoramentos, 2011.

GUTTMANN, J. A Filosofia do Judaísmo. São Paulo: Perspectiva, 2003.

HOUAISS, A. Dicionário da Língua Portuguesa. Rio de Janeiro: Objetiva, 2009.

HUGO DE SÃO VITOR, Didascálicon. Da arte de ler. Petrópolis: Ed. Vozes, 2001.

JAPIASSÚ, H. e MARCONDES, D. Dicionário Básico de Filosofia. Rio de Janeiro: Zahar, 2006.

LIVI, A. Lessico della Filosofia. Milano: Ares, 1995.

LUCE, J. V. Curso de Filosofia Grega. Do séc. VI a. C. ao séc. III d.C.. Rio de Janeiro: Jorge Zahar Editor, 1994.

MELENDO, T. Metafísica da Realidade. As relações entre filosofia e vida. São Paulo: I.B.F.C. "Raimundo Lúlio", 2002. 
Iniciação à Filosofia: Razão, Fé e Verdade. São Paulo, I.B.F.C., 2005.

PYM, A. Exploring Translation Theories, Routledge, 2010.

Teorías contemporâneas de la traducción. Routledge, 2012.

REZENDE, A. (org.). Curso de Filosofia. Rio de Janeiro: Jorge Zahar Editor, 2004.

RICOEUR, P. Sur la Traduction. Bayard, 2004.

RINCÓN ÁLVAREZ, Mozárabes y Mozarabias. Salamanca: Ed. Universidad Salamannca, 2003.

ROONEY, A. A História da Matemática. São Paulo: M.Books, 2012.

ROPS, J.-D. A Igreja dos tempos bárbaros. São Paulo: Quadrante, 1993.

SARANYANA, J.-I. A Filosofia Medieval. Das origens Patrísticas à Escolástica Barroca. São Paulo: I.B.F.C. "Raimundo Lúlio", 2006.

SAVAGNONE, G. Theoria. Alla ricerca della filosofia. Brescia: La Scuola, 1991.

STRECKER, K. Introduction à l'Étude du Latin Médiéval. Paris: Ed. Droz, 1946.

STORCK, A. C. "A divisão das ciências segundo Avicena: textos e notas". In: SOUZA PEREIRA, R. H. (org.). Busca do conhecimento. Ensaios de filosofia medieval no islã. São Paulo: Paulus, 2007, p. 265-288.

WEBER, E. "La classification des sciences selon Avicenne à Paris vers 1250". In:

RASCHED, R.; JOLIVET, J. (org.). Etudes sur Avicenne. Paris: Les Belles Lettres, 1984, p. 77-101. 